\title{
Arvīds Jakovịevs
}

\section{Difūzo gliomu imūnhistoḳimiskā klasifikācija}

Promocijas darba kopsavilkums zinātniskā doktora grāda "zinātnes doktors (Ph.D.)" iegūšanai

Nozare - medicīnas bāzes zinātnes, tai skaitā farmācija

Apakšnozare - patoloǵija

Rīga, 2021 


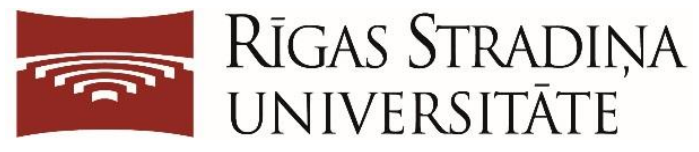

\author{
Arvīds Jakovḷevs \\ ORCID 0000-0002-9703-4922
}

\title{
Difūzo gliomu imūnhistoķīmiskā klasifikācija
}

Promocijas darba kopsavilkums zinātniskā doktora grāda "zinātnes doktors (Ph.D.)" iegūšanai

Nozare - medicīnas bāzes zinātnes, tai skaitā farmācija Apakšnozare - patologija

Rīga, 2021 
Promocijas darbs izstrādāts Rīgas Stradiṇa universitātē, Latvijā

Promocijas darba vadītāji:

Dr. habil. med. profesors Jānis Gardovskis,

Rìgas Stradiṇa universitāte, Latvija

Dr. med. profesore Ilze Štrumfa,

Rīgas Stradiṇa universitāte, Latvija

Oficiālie recenzenti:

Dr. habil. med. profesore Māra Pilmane,

Rīgas Stradiṇa universitāte, Latvija

Dr. med. profesore Ave Minajeva,

Tartu Universitāte, Igaunija

Dr. med. profesors Arvydas Laurinavicius,

Viḷnas Universitāte, Lietuva

Promocijas darbs tiks aizstāvēts "Medicīnas bāzes zinātnes, tai skaitā farmācija" promocijas padomes atklātā sēdē 2021. gada 10. jūnijā plkst. 12.00, attālināti Zoom tiešsaistes platformā

Ar promocijas darbu var iepazīties RSU bibliotēkā un RSU tīmekḷa vietnē: https://www.rsu.lv/promocijas darbi

Promocijas padomes sekretāre:

Dr. med. profesore Juta Kroiča 


\section{Satura rādītājs}

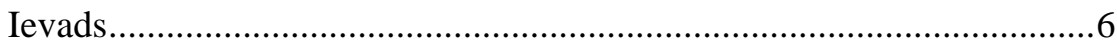

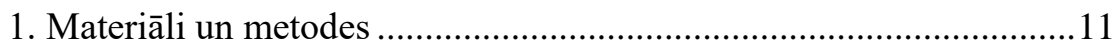

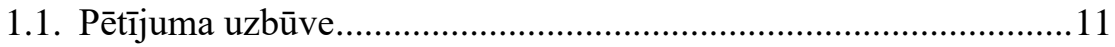

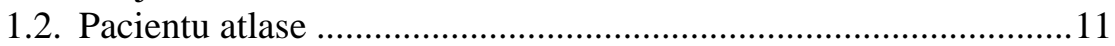

1.3. Audu apstrāde un mikroskopiska izmeklēšana ................................12

1.4. Imūnhistoḳīmiskā vizualizācija un izvērtēšana .............................13

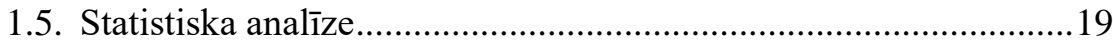

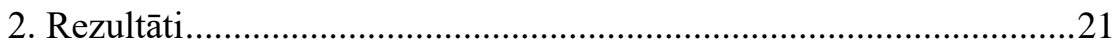

2.1. Pētāmās grupas raksturojums......................................................21

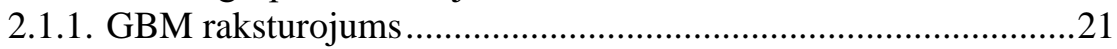

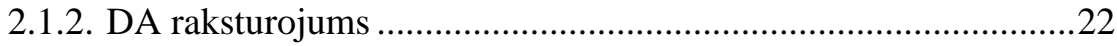

2.2. Morfologiskais raksturojums ………………..............................2

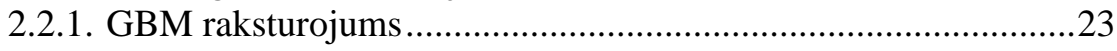

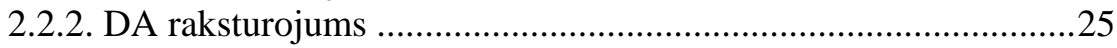

2.3. GBM un DA imūnhistoḳimiskais profils....................................26

2.4. Asociācijas un korelācijas starp klīniskajiem un imūnhistoḳīmiskajiem parametriem .................................................33

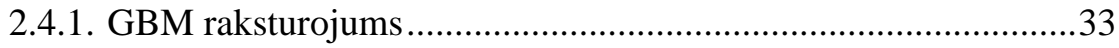

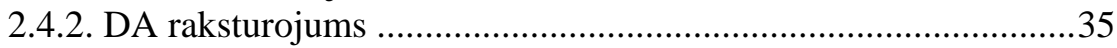

2.5. Asociācijas un korelācijas starp imūnhistoḳīmiskajiem

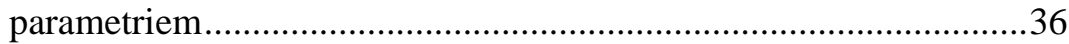

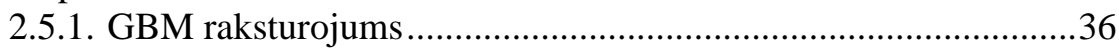

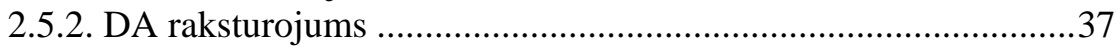

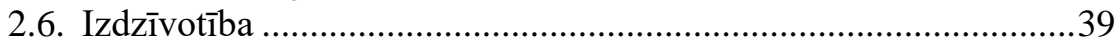

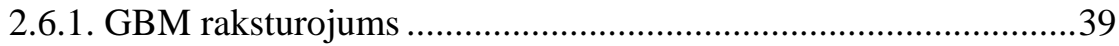

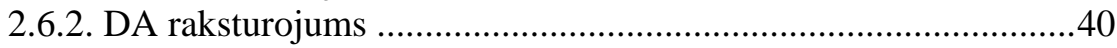

2.7. Asociācijas starp izdzīvotības laiku un klīniskajiem parametriem 41

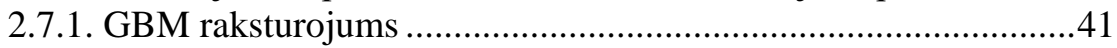

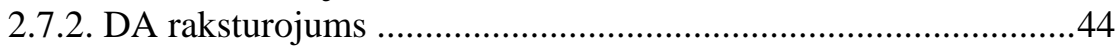

2.8. Asociācijas starp izdzīvotības laiku un imūnhistoḳīmiskajiem

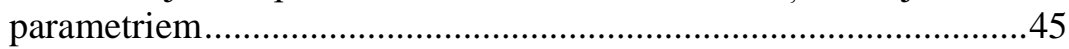

2.8.1. GBM imūnhistoķīmiskie prognostiskie marķieri .........................45

2.8.2. DA imūnhistoḳīmiskie prognostiskie marḳieri .............................48

2.9. Gliomu imūnhistoḳīmiskie subtipi un izdzīvotības laiks ................50 


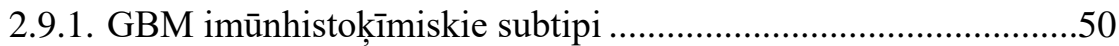

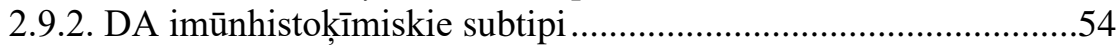

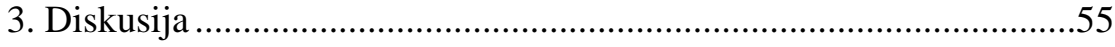

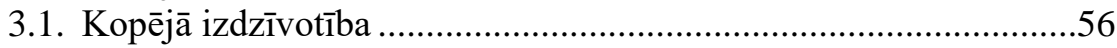

3.2. Klīniskie un morfologiskie parametri ............................................57

3.3. Gliomu imūnhistoḳīmiskais profils.................................................60

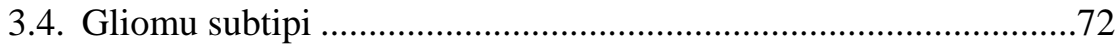

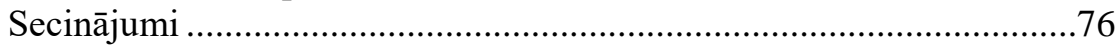

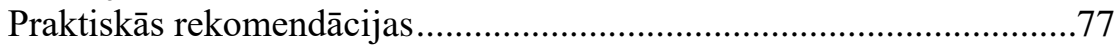

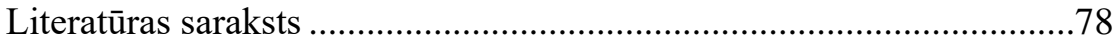




\title{
Darbā izmantotie saīsinājumi
}

\author{
Ag antigēns \\ CD cluster of differentiation \\ TI ticamības intervāls \\ CNS centrālā nervu sistēma \\ DA difūza astrocitoma \\ GBM glioblastoma \\ HE hematoksilīna-eozīna krāsošanas metode \\ IDH izocitrātdehidrogenāze \\ IHḲ imūnhistoḳīmija \\ IQR starpkvartịlu diapazons (interquartile range) \\ MVB mikrovaskularizācijas blīvums \\ NP nav pielietojams
}

PDGFRA trombocītu atbrīvotā augšanas faktora receptors alfa

PVO Pasaules Veselības organizācija

SD standarta novirze (standart deviation)

TCGA Vēža genoma atlass (The Cancer Genome Atlas)

MR magnētiskās rezonanses izmeklējums 


\section{Ievads}

Glioblastoma (GBM) ir viens no biežāk sastopamajiem un agresīvākajiem centrālās nervus sistēmas (CNS) audzējiem, kas ir augstākās anaplāzijas pakāpes glioma (4. anaplāzijas pakāpe). Neskatoties uz standartterapiju, kas iekḷauj maksimāli iespējamu audzēja rezekciju, kuru papildina ar adjuvantu ķīmijterapiju ar temozolamīdu un radioterapiju, prognoze pacientiem ar GBM ir loti slikta - mediānais izdzīvotības laiks ir 12 līdz 15 mēneši (Stupp et al., 2005). Sakarā ar to, ka audzēja šūnas plaši infiltrē apkārtējos galvas smadzeṇu audus, pilnīga ķirurgiska rezekcija GBM nav iespējama, un līdz ar to audzēja recidīvs ir neizbēgams (Roy et al., 2015). Ķīmijterapijas un staru terapijas iespējas arī ir ierobežotas izteikto audzēju šūnu rezistences dēl, kā arī ķīmijterapeitisko līdzekḷu molekulām nozīmīgs šḳērslis ir hematoencefâliskā barjera.

Jaunu potenciālu imūnhistoḳīmisku un molekulāru marķieru atklāšanu un pētīšana varētu uzlabot zināšanas par kritiskām molekulārām izmaiṇām, kas veicina audzēja attīstību, un šādas zināšanas palielina iespēju izveidot efektīvu uz mērḳa molekulu vērstu terapiju nākotnē. Jauni molekulāri un imūnhistoḳīmiski prognostiski marķieri var uzlabot ārstēšanu un, iespējams, arī radītu iespēju dalīt pacientus vairākās prognostiskās grupās ar atškirīgu ārstēšanas pieeju, kas padarītu terapiju personalizētāku.

GBM ir atklāts ḷoti maznozīmīgu prognostisku marķieru, piemēram, 06metilguanīn-DNS-metiltransferāzes (MGMT) gēna promotera metilācija un IDH1 gēna mutācijas ir pašlaik vien̄̄gie labi zināmie, klīniski nozīmīgie prognostiskie un predikatīvie molekulārie faktori (Kaminska et al., 2019; Kim and Liau, 2012). Visbiežāk sastopamā IDH1 gēna mutācija - IDH1 R132H - ir viegli nosakāma arī ar imūnhistoḳīmijas metodi (IHĶ) pret gēna mutācijas ekspresijas produktu - mutantu IDH1 R132H proteīnu (Thota et al., 2012). 
Proteīni, kuru ekspresija ir saistīta ar audzēja pamatīpašībām (proliferāciju, invāziju, šūnas cikla regulāciju) varētu tikt izmantoti kā potenciālie audzēja prognostiskie vai predikatīvie marķieri. Šādi protē̄ni, kuri hipotētiski varētu būt iesaistīti gliomu patoǵenēzē, ir proliferācijas marḳieris Ki-67, audzēja supresora proteīns - p53, šūnas cikla regulētāji - p21 un p27. Taču attiecībā uz šo proteīnu prognostisko lomu literatūrā ir loti pretrunīgi dati, tādēḷ nepieciešami papildu pētījumi šajā jomā (Le Mercier et al., 2012; Popova et al., 2014). Literatūrā ir arī daudz diskusiju par gliomu cilmes šūnām un ar tām saistītiem marķieriem - CD133 un CD44 (Bhat et al., 2013; Dong et al., 2019; Ortensi et al., 2013). Daudzi jaunākie pētījumi ir vērsti uz gliomu molekulāro un ǵenētisko īpatnību izpēti, veicot apjomīgu audzēja šūnu genoma sekvencēšanu, ekspresijas profilēšanu un epiğenētisko analīzi. Mūsdienās, pateicoties šiem apjomīgiem pētījumiem un balstoties uz iegūto datu plašu analīzi, ir pierādījumi par vairāku GBM subtipu eksistenci. Verhaak et al., autoru kolektīvs, veicot plašu gēnu sekvencēšanu un ekspresijas profilēšanu gliomās, aprakstīja četrus GBM molekulāros subtipus - klasisko, mezenhimālo, proneirālo un neirālo. Katram subtipam raksturīgas noteiktas ǵenētiskas izmainas: IDH1 un TP53 gēnu mutācijas un PDGFRA gēna amplifikācija, raksturīga proneirālajam subtipam, kurš korelē ar labāku prognozi un mazāku vecumu, taču agresīva adjuvanta terapija šim subtipam nesniedz nekādu uzlabojumu. EGFR gēna amplifikācija bieži konstatēta klasiskajam subtipam, $N F 1$ gēna delēcija un mezenhimāliem audiem specifisku gēnu (CD44, MET, YLK-40) ekspresija raksturīga mezenhimālam subtipam, bet neironiem specifisku gēnu (NELF, GABRA) ekspresija norāda uz neironālu GBM subtipu (Verhaak et al., 2010). Ir aprakstīti arī daudzi citi gliomu subtipēšanas mēǵinājumi, kuros konstatēti līdzīgi molekulārie subtipi (Brennan et al., 2009; Liang et al., 2005; Phillips et al., 2006; Teo et al., 2019). Pagaidām tiek risināts jautājums, kā šos molekulāros datus padarīt izmantojamus rutīnas klīniskajā praksē. GBM molekulārā subtipēšana ir 
iespējama un varētu būt daudzsološa, bet rutīnas praksē ir nepieciešama vienkārša un pieejama metode, imūnhistoķīmiska vizualizācija (IHĶ) varētu būt lētāks analogs, kas aizstātu sarežǵītas un laikietilpīgas molekulārās analīzes metodes. Pasaulē pagaidām ir salīdzinoši maz pētījumu par IHĶ izmantošanu gliomu subtipēšanā. Piemēram, Le Mercier et al., izmantojot minimālu IHĶ marķieru skaitu, - EGFR, PDGFRA un p53, veiksmīgi spēja izšķirt GBM proneirālo un klasisko subtipu. Šis autoru kolektīvs pierādīja labāku izdzīvotību pacientiem ar proneirālu GBM, savukārt pacienti ar klasisku GBM subtipu uzrādīja labāku reakciju, saņemot agresīvu adjuvantu terapiju (Le Mercier et al., 2012). Lai spriestu par IHĶ praktisko nozīmi gliomu subtipēšanā, kā arī secinātu par atsevišķu IHĶ marķieru predikatīvu un prognostisko lomu, ir nepieciešami papildu pētījumi.

Šì pētījuma mērḳis ir izvērtēt gliomu - glioblastomas (GBM) un difūzu astrocitomu (DA) morfologiisko un imūnhistoḳīmisko profilu, kā arī izvērtēt atsevišķu imūnhistoḳīmisku marķieru prognostisko lomu.

Lai sasniegtu šo mērḳi, ir izvirzīti šādi uzdevumi:

1) raksturot gliomu morfoloğisko struktūru;

2) izvērtēt angioǵenēzi, nosakot mikrovaskularizācijas blīvumu (MVB) GBM un DA audos;

3) izvērtēt proliferācijas frakciju (Ki-67), kā arī šūnas cikla regulatoru (p21 un p27), aberanta p53 proteīna, PDGFRA un CD44 ekspresiju GBM un DA audos;

4) izvērtēt IDH1 R132H mutācijas biežumu ar IHĶ metodi GBM un DA audos;

5) izvērtēt jebkuras korelācijas un asociācijas starp klīniskajiem, morfoloğiskajiem un imūnhistoķīmiskajiem parametriem;

6) veikt GBM un DA pacientu izdzīvotības laika analīzi un faktorus, kas to ietekmē; 
7) izvērtēt gliomu subtipēšanas iespējas ar IHĶ metodi un analizēt kopsakarības starp klīniskajiem, morfolog̣iskajiem un imūnhistoḳīmiskajiem parametriem.

\section{Zinātniskie pieṇēmumi jeb darba hipotēzes:}

1) morfoloǵiskajiem un imūnhistoḳīmiskajiem parametriem ir prognostiska nozīme gliomās;

2) gliomu subtipēšana ir iespējama, izmantojot imūnhistokīimijas metodi.

\section{Zinātniskā novitāte:}

1) šajā darbā tika pārbaudīta hipotēze par to, vai, izmantojot IHĶ metodi, ir iespējama gliomu subtipēšana;

2) ŗeǵionālā aspektā ir pirmais pētījums Latvijā, kurā plaši izvērtēts gliomu morfolog̣iskais un imūnhistoḳīmiskais raksturojums, kā arī veikta izdzīvotības laika analīze;

3) zinātniskā darba ietvaros izpētīti vairāki imūnhistoḳīmiski marķieri, kuru agrākā diagnostiska un prognostiskā vērtība ir bijusi pretrunīga. Šādi rezultāti vairo pētījumu datus, kas balstīit uz pierādījumiem.

\section{Personīgais ieguldījums}

Autors ir veicis visas pētījuma stadijas, t. sk. pētījuma plānojumu un imūnhistoḳīmisko marķieru izvēli, zinātnisko datu ieguvi un statistisko analīzi. Autors veica arī imūnhistoḳīmisko vizualizāciju un ir darbā iekḷauto makroskopisko un mikroskopisko attēlu autors. 


\section{Ētiskie apsvērumi}

Pētījums ir veikts saskaņā ar Helsinku deklarāciju un Rīgas Stradiņa universitātes Ētikas komitejas ațauju. 


\section{Materiāli un metodes}

\subsection{Pētījuma uzbūve}

Pētījums veikts kā retrospektīvs, uz pierādījumiem balstīts, gliālu audzēju morfologisks un imūnhistoḳīmisks izvērtējums. Laika periodā no 2009. līdz 2014. gadam atlasīti secīgi, operēti 172 gliomu gadījumi - 146 glioblastomas (GBM) (4. anaplāzijas pakāpe) un 26 difūzas astrocitomas (DA) (2. anaplāzijas pakāpe). Anaplastiskas astrocitomas (3. anaplāzijas pakāpe) netika iekḷautas pētījumā, jo tika izvērtētas gliomas ar divām krasi atšḳirīgām anaplāzijas pakāpēm.

\subsection{Pacientu atlase}

Pētījumā tika iekḷauti 172 gliomu gadījumi - 146 GBMs un 26 DAs, kas atlasīit laika periodā no 2009. līdz 2014. gadam no vienas universitātes slimnīcas (Paula Stradiṇa Klīniskā universitātes slimnīca). Audzēju diagnoze tika noteikta pēc Pasaules Veselības organizācijas (PVO) centrālās nervu sistēmas (CNS) audzēju klasifikācijas 2016. gada izdevuma. Pētījumā tika iekḷauti pacienti ar GBM un DA diagnozi, atbilstoši šãdiem ieslēgšanas kritērijiem:

1) pacienti ar histologiski pierādītu GBM un DA diagnozi, vadoties pēc PVO, CNS audzēju klasifikācijas, 2016.;

2) pietiekošs audu materiāla daudzums (tikai neiroḳirurğiski rezecētu gliomu materiāls);

3) kvalitatīvs audzēja audu materiāls (vismaz $10 \%$ no materiāla kopējā apjoma veido saglabāti audzēja audi bez nekrozēm);

4) pirmreizēji diagnosticēti gliomu gadījumi bez iepriekšējas adjuvantas terapijas. 
Izslēgšanas kritēriji bija šādi:

1) cita histologískā tipa gliāli audzēji, kā arī audzēji ar divdomīgu, šaubīgu morfoloǵiju;

2) mazs materiāla apjoms vai materiāls, kurš iegūts galvas smadzeṇu stereotaktiskās biopsijās;

3) stipri bojāts audu materiāls: ar plašām nekrozēm vai audu bojājuma artefaktiem, kas veido vairāk par 90 \% no materiāla kopējā apjoma.

Pacientu demogrāfiskie dati (dzimums, vecums), kā arī dati par audzēja izmēriem, lokalizāciju un adjuvantas terapijas veidu (ķīmijterapija ar temozolamīdu vai/un radioterapija) tika iegūti no slimību vēsturēm un operācijas materiāla nosūtījuma pavadzīmēm. Radiologiskie dati par audzēja izmēriem un lokalizāciju tika arī pārbaudīti pēc magnētiskās rezonanses (MR) izmeklējuma aprakstiem.

\subsection{Audu apstrāde un mikroskopiska izmeklēšana}

Neiroḳirurgisku operāciju laikā iegūtais materiāls ir fiksēts formalīnā, un pilnīgi viss saņemtais materiāls ir ieguldīts parafīna blokos turpmākai apstrādei un histoloğisko griezumu sagatavošanai. Iegūtie gliomu audu paraugi ir fiksēti neitrālā buferētā $10 \%$ formalīnā (Sigma-Aldrich, Saint Louis, Amerikas Savienotās Valstis (ASV)) un secīgi inkubēti pieaugošas koncentrācijas 2-propranololā (Sigma-Aldrich), Histograde ksilolā (J. T. Baker, Deventer, Nīderlande) un paraplastā (Diapath S.r.l., Bergamo, Itālija), veicot šo apstrādi vakuuma infiltrācijas procesorā Tissue-Tek® VIP 5 (Sakura Seiki Co., Ltd., Nagano, Japāna). Apstrādātie audi tika ieguldīti paraplastā (Diapath S.r.l.), izmantojot ieguldī̌̌anas sistēmu TES 99 (Medite GmbH, Burgdorf, Vācija). Parafīna blokos ieguldītie audu paraugi tika sagriezti 4 mikronu biezos griezumos ar mikrotomu Microm HM 360 (Thermo Fisher Scientific, Inc., Waltham, ASV) un uztverti uz priekšmetstikliem (Menzel-Glaser, 
Braunschweig, Vācija). Griezumi tika krāsoti ar hematoksilīnu un eozīnu audu krāsojamā automātā TST 44 (Medite Medizintechnik, Burgdorf, Vācija) un pārklāti ar segstikliņu (Biosigma, Cona, Itālija), izmantojot automatizētu segstikliṇu pārklājēju (Dako, Glostrup, Dānija) un Pertex līmi (Histolab, Gothenburg, Zviedrija). Ar hematoksilīnu un eozīnu krāsotie mikropreparāti tika izvērtēti gaismas mikroskopā (Zeiss Axiolab, Vācija), iegūstot datus par audzēja histoloǵisko tipu, atbilstoši PVO CNS audzēju klasifikācijai, 2016. Tika arī izvērtēta izmeklēšanai pieejamā materiāla kvantitāte un kvalitāte, un materiāls, kurš neatbilst ieslēgšanas kritērijiem, netika tālāk analizēts.

\subsection{Imūnhistoḳīmiskā vizualizācija un izvērtēšana}

Pētāmo antigēnu imūnhistoḳīmiskā vizualizācija (IHĶ) veikta formalīnā fiksētos, parafīnā ieguldītos audzēja audos un kontroles audos. Lai veiktu IHĶ, katrā gadījumā tika identificēts 1 audu bloks, kurā bija ietverti saglabāti audzēja audi (bez plašām nekrozēm). IHĶ dati netika interpretēti audu griezumos, kuros atklājās pilnīga nekroze vai audzēja izzudums.

IHĶ mērḳiem ar elektronisko rotācijas mikrotomu Microm HM 360 tika sagatavoti trīs mikrometru biezi griezumi uz elektrostatiski uzlādēta priekšmetstikla (Histobond, Marienfeld, Vācija), un audi tika pakḷauti deparafinizācijai graduētā spirta šḳīdumā (Sigma-Aldrich) un Histograde ksilolā (J.T. Baker). Termāla antigēna struktūras atjaunošana tika veikta mikroviḷnu krāsnī (3×5 min), izmantojot bāzisku TEG (pH 9,0) buferi (DAKO). Pēc endogēnās peroksidāzes bloḳēšanas (Sigma-Aldrich) griezumi tika inkubēti ar primāro antivielu istabas temperatūrā magnētiskā inkubatora kamerā. Katrai antivielai pirms izmantošanas veikta standartizācija, izmantojot kontroles audus atbilstoši ražotāja specifikācijas lapā minētajām instrukcijām. Kad bija atrasta antivielas optimāla koncentrācija, tā tika pārbaudīta ar gliomu audiem. Pielietotās primārās antivielas klonalitāte, sugas izcelsme, sugas specifiskums, 
darba atšķaidījums un inkubācijas laiks minēti 1.1. tabulā. Piesaistītās primārās antivielas tika noteiktas ar polimēru vizualizācijas sistēmu EnVision, kas konjugēta ar peroksidāzi. Kā hromogēns tika izmantots 3,3'-diaminobenzidīns. Kodolu krāsojumam izmantots Meijera hematoksilīns.

1.1. tabula

\section{Primāru antivielu paneḷa raksturojums}

\begin{tabular}{|l|l|l|l|l|}
\hline \multicolumn{1}{|c|}{ Antigēns } & \multicolumn{1}{c|}{$\begin{array}{c}\text { Antivielas } \\
\text { raksturojums }\end{array}$} & \multicolumn{1}{|c|}{ Klons } & Atšḳaidījums & Ražotājs \\
\hline Ki-67 & $\begin{array}{l}\text { Monoklonāla peles } \\
\text { Av pret cilvēka Ag }\end{array}$ & MIB-1 & $1: 100$ & Dako \\
\hline p53 & $\begin{array}{l}\text { Monoklonāla peles } \\
\text { Av pret cilvēka Ag }\end{array}$ & DO-7 & $1: 400$ & Dako \\
\hline $\begin{array}{l}\text { p21 } 1^{\text {WAF1/Cip1 }} \\
\text { protein }\end{array}$ & $\begin{array}{l}\text { Monoklonāla peles } \\
\text { Av pret cilvēka Ag }\end{array}$ & SX118 & $1: 25$ & Dako \\
\hline $\begin{array}{l}\text { p27 Kip1 } \\
\text { protein }\end{array}$ & $\begin{array}{l}\text { Monoklonāla peles } \\
\text { Av pret cilvēka Ag }\end{array}$ & SX53G8 & $1: 50$ & Dako \\
\hline $\begin{array}{l}\text { Mutant IDH } \\
\text { R132H }\end{array}$ & $\begin{array}{l}\text { Monoklonāla peles } \\
\text { Av pret cilvēka } \\
\text { mutantu IDH1 } \\
\text { R132H protēinu }\end{array}$ & H09 & $1: 50$ & Dianova \\
\hline PDGFRA & $\begin{array}{l}\text { Poliklonāla truša Av } \\
\text { pret cilvēka Ag }\end{array}$ & Polyclonal & $1: 200$ & Abcam \\
\hline CD44 & $\begin{array}{l}\text { Monoklonāla peles } \\
\text { Av pret cilvēka Ag }\end{array}$ & DF1485 & $1: 50$ & Dako \\
\hline CD34 & $\begin{array}{l}\text { Monoklonāla peles } \\
\text { Av pret cilvēka Ag }\end{array}$ & QBEnd10 & $1: 50$ & Dako \\
\hline
\end{tabular}

Saīsinājumi tabulā: Av, antiviela; Ag, antigēns.

Pēc vizualizācijas audu griezumi tika segti ar segstikliņu (Biosigma). Veiktas pozitīvas un negatīvas kvalitātes kontrolreakcijas, gūstot adekvātus rezultātus. Imūnhistoḳīmisko marķieru ekspresija tika izvērtēta gaismas mikroskopā, izmantojot augsta palielinājuma redzes lauku 400× (t. i., 40× objektīvu un 10× okulārās lēcas; laukums $0,65 \mathrm{~mm}^{2}$ ). Imūnhistoḳīmisko marķieru ekspresija tika izvērtēta atbilstoši intensitātei: zema, vidēja un augsta intensitāte. Marḳieru ekspresija tika uzskatīta par pozitīvu, ja ekspresijas 
intensitāte bija vidēja vai augsta (Ryu et al., 2018; van Diest et al., 1997). Ekspresijas intensitātes pakāpe (viegla, vidēja, augsta) ir redzama 1.1. attēlā uz CD44 ekspresijas piemēra.

Lielākajai daḷai marḳieru (Ki-67, p53, p21, p27, CD44, CD34) nukleāra, citoplazmatiska vai membranoza pozitivitāte ir vērtēta kvantitatīvi kā pozitīvās šūnas (\%) no kopējā šūnu skaita.

PDGFRA ekspresijas vērtēšanā izmantota gan kvantitatīva, gan semikvantitatīva metode (0-9\% imūnreaktīvo šūnu - negatīvs, $10-50 \%$ - fokāli pozitīvs, $>50 \%$ pozitīvs). IDH1 R132H mutanta proteīna ekspresija ir vērtēta tikai kā pozitīvs $(+)$ vai negatīvs $(-)$ rezultāts (1.2. attēls).

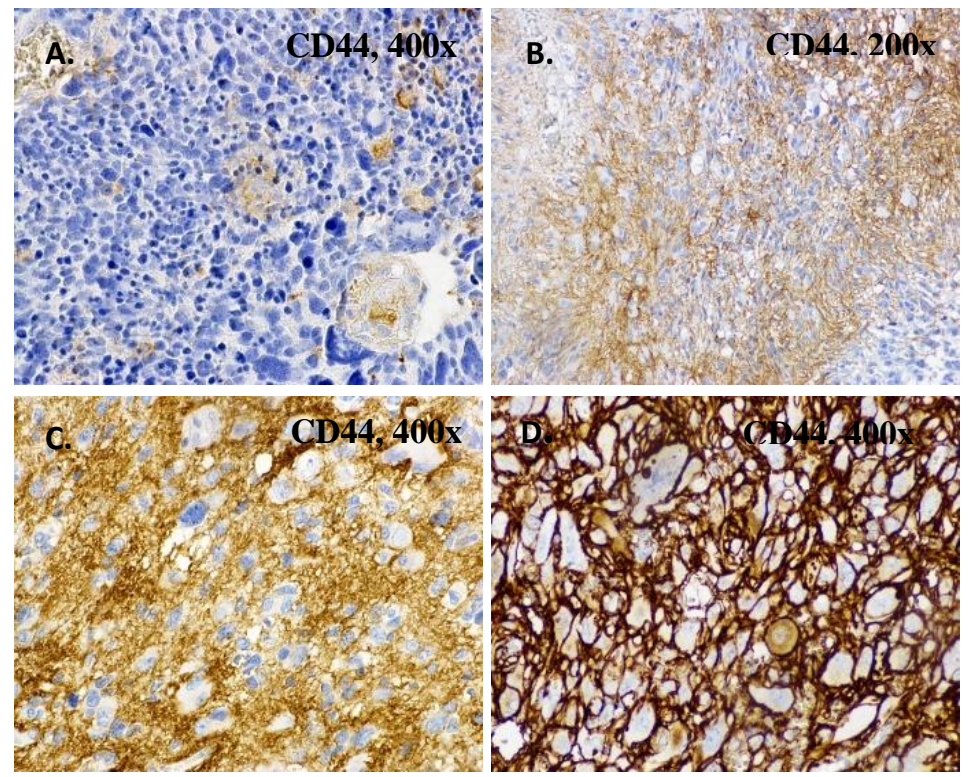

1.1. attēls. CD44 ekspresijas intensitāte GBM: A - nav ekspresijas; B - zema ekspresija; C - vidēja ekspresija; D - augsta ekspresija, anti-CD44

Attēla palielinājums 200×(B) un 400× (A,C,D) 

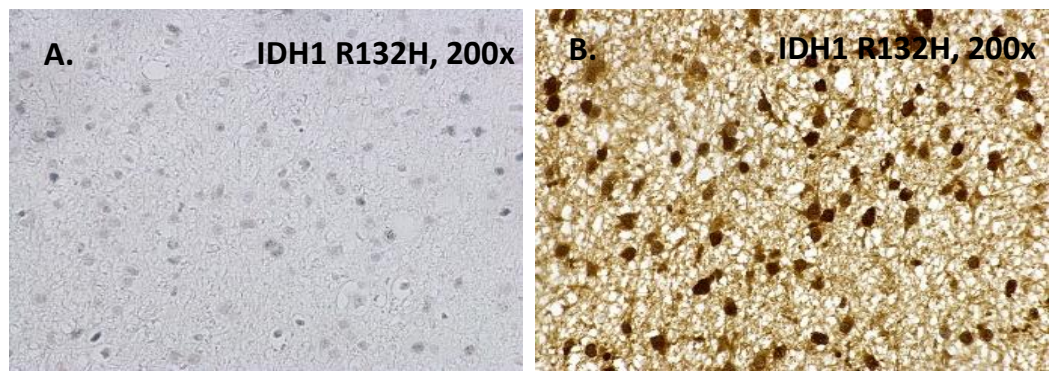

1.2. attēls. IDH1 R132H mutanta proteīna ekspresija DA:

A, negatīvs; B, pozitīvs; anti-IDH1 R132H

Attēla palielinājums 200x.

Mikrovaskularizācijas blīvuma noteikšanai (MVB) endoteliālā diferenciācija tika noteikta ar membranozu CD34 ekspresiju. MVB izvērtēts pēc Veidnera pieejas (Weidner et al., 1991). Pirmais solis bija paaugstināta mikrovaskulārā blīvuma apvidus t.s. karstā punkta atrašana mērḳa audos. Šie apvidi tika identificēti, pārskatot visu audu materiālu zemā mikroskopa palielinājumā 100x (t. i., 10x objektīva un 10x okulāra lēcas) (1.3. attēls). Individuālas vaskulārās struktūras tika skaitītas 400× laukā (t. i., 40× objektīva lēca un 10× okulāra lēca; $0,65 \mathrm{~mm}^{2}$ laukumā). Bija vērtēti tikai sīkie asinsvadi, lielāki asinsvadi ar muskuḷslāni sieniņā netika skaitīti.

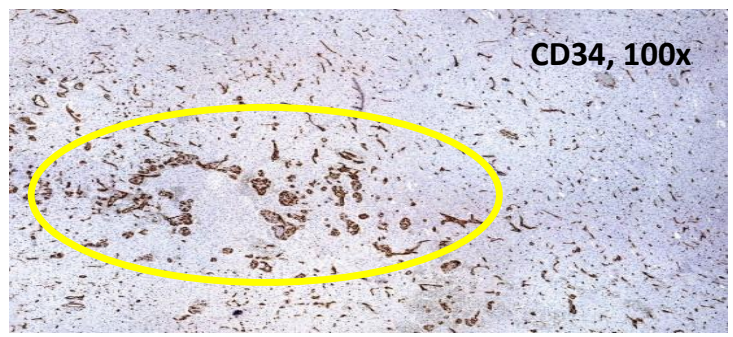

1.3. attēls. MVB vērtēšana GBM. "Karstais punkts" parādīts dzeltenajā aplī. Anti-CD34

Attēla palielinājums 100x. 


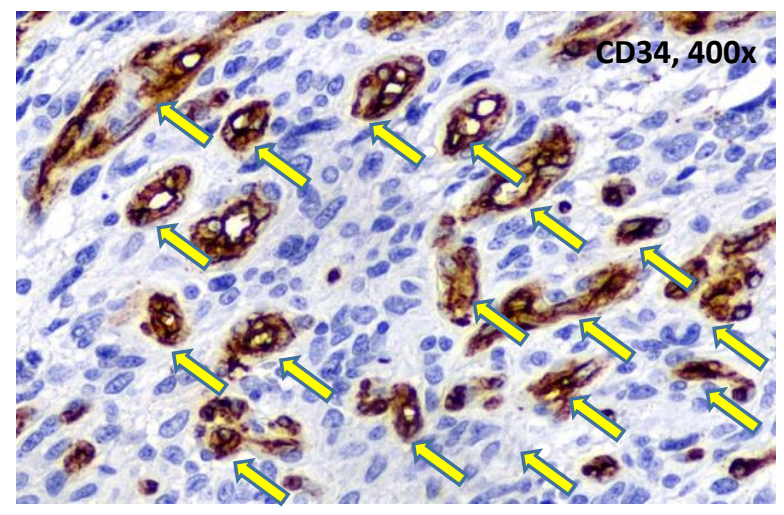

\section{4. attēls. Mikroasinsvadi (bultiņas) GBM. Anti-CD34}

Attēla palielinājums $400 \times$.

Attiecībā uz katru imūnhistoḳīmisko marķieri, lai rezultātu varētu uzskatīt par pozitīvu, imūnpozitīvo šūnu relatīvajam daudzumam bija jāsasniedz noteikta robežvērtība (cut-off). Pasaules literatūrā ir daudz domstarpību attiecībā uz pielietoto marķieru robežvērtībām gliālu audzēju audos, un dažādi autori bieži pielieto atšķirīgas robežvērtības. Tādēḷ šajā pētījumā tika izmantotas divas robežvērtības - viena tika izvēlēta, vadoties pēc citu autoru izmantotajām robežvērtībām gliomu pētījumos starptautiskajā literatūrā, par otru robežvērtību tika pieņemts imūnhistoḳīmiskā marķiera mediānas ekspresijas līmenis. Vērtējot MVB, par robežvērtību tika pieņemta tikai mediānas vērtība, jo pasaules literatūrā ir ḷoti maz pētījumu ar MVB izvērtējumu gliālos audzējos.

Šajā pētījumā imūnhistoḳīmisko marḳieru ekspresijas vērtēšanā izmantotās robežvērtības gan GBM, gan DA parādītas 1.2. tabulā. 
Imūnhistoḳīmisko marḳieru ekspresijas robežvērtības GBM un DA

\begin{tabular}{|c|c|c|c|}
\hline Markieris & GBM & DA & $\begin{array}{r}\text { Atsauces } \\
\end{array}$ \\
\hline $\mathrm{Ki}-67$ & $\begin{array}{l}25 \% \text { un } \\
41 \% \text { (mediāna) }\end{array}$ & $\begin{array}{l}3 \% \text { un } \\
5,5 \% \text { (mediāna) }\end{array}$ & $\begin{array}{l}\text { (Jin et al., 2011; Neder } \text { et al., } \\
\text { 2004) }\end{array}$ \\
\hline p53 & $\begin{array}{l}10 \% \text { un } \\
15 \% \text { (mediāna) }\end{array}$ & $\begin{array}{l}10 \% \text { un } \\
52 \% \text { (mediāna) }\end{array}$ & $\begin{array}{l}\text { (Popova et al., 2014; } \\
\text { Wang et al., 2014) }\end{array}$ \\
\hline CD44 & $\begin{array}{l}50 \% \text { un } \\
86,5 \% \\
\text { (mediāna) } \\
\end{array}$ & $\begin{array}{l}50 \% \text { un } \\
8,5 \% \text { (mediāna) }\end{array}$ & (Popova et al., 2014) \\
\hline PDGFRA & $\begin{array}{l}50 \% \text { un } \\
1 \% \text { (mediāna) }\end{array}$ & $\begin{array}{l}50 \% \text { un } \\
42 \% \text { (mediāna) }\end{array}$ & (Popova et al., 2014) \\
\hline p21 & $\begin{array}{l}20 \% \text { un } \\
19 \% \text { (mediāna) }\end{array}$ & $\begin{array}{l}20 \% \text { un } \\
2,5 \% \text { (mediāna) }\end{array}$ & (Trabelsi et al., 2016) \\
\hline $\mathrm{p} 27$ & $\begin{array}{l}70 \% \text { un } \\
74 \% \text { (mediāna) }\end{array}$ & $\begin{array}{l}70 \% \text { un } \\
92 \% \text { (mediāna) }\end{array}$ & $\begin{array}{l}\text { (Faria } \text { et al., 2007; } \\
\text { Yang et al., 2011) }\end{array}$ \\
\hline MVB & 35 \% (mediāna) & $\begin{array}{l}13,0 \% \\
\text { (mediāna) }\end{array}$ & $\mathrm{NP}$ \\
\hline
\end{tabular}

Saīsinājumi tabulā: NP, nav pielietojams, MVB, mikrovaskularizācijas blīvums, PDGFRA, trombocītu atbrīvotā augšanas faktora receptors alfa, GBM, glioblastoma, DA, difüza astrocitoma.

GBM subtipa noteikšanai (pēc Verhaak et al., 2010), izmantoti dati par četru proteīnu ekspresiju: p53, IDH1 R132H, PDGFRA un CD44, atbilstoši Verhaak et al., 2010 pētījumā aprakstītajām molekulārām signatūrām. Balstoties uz šo proteīnu ekspresiju, pētījumā tika izšķirtas trīs GBM subtipu kategorijas: proneirāls, mezenhimāls un neklasificēts subtips.

Šo gliomas subtipu definējums pēc proteīnu ekspresijas signatūrām bija šāds: proneirālu subtipu raksturoja augsta p53 ekspresija un/vai augsta PDGFRA ekspresija, un/vai IDH1 R132H pozitivitāte; mezenhimālu subtipu raksturoja augsta CD44 ekspresija un zema proneirālo marķieru (p53, PDGFRA, IDH1 R132H) ekspresija. Visi pārējie audzēju gadījumi, kurus neizdevās iekḷaut atbilstoša subtipa kategorijā, tika nosaukti par neklasificētu subtipu, apzīmēti ar "Cits". Imūnhistoḳīmisko subtipu iedalīšanas algoritms ir parādīts 1.5 attēlā. 


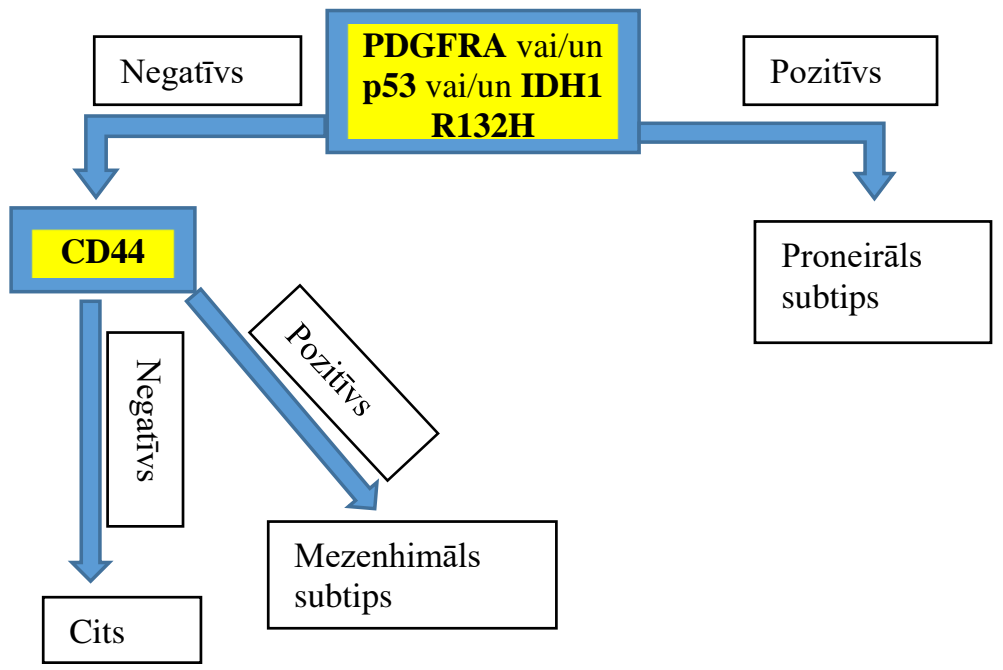

1.5. attēls. Gliomu imūnhistoḳīmiska subtipēšana (algoritms)

Visi mikropreparāti tika izvērtēti gaismas mikroskopā (Zeiss Axiolab, Vācija). Morfologiiskie un imūnhistoḳīmiskie attēli uzņemti ar Kappa Image Base programmu (KAPPA opto-electronics Inc., ASV), izmantojot Axiolab (Zeiss, Oberkochen, Vācija) mikroskopu kā optisko sistēmu un Kappa CF 11 DSP kameru (KAPPA opto-electronics Inc., ASV).

\subsection{Statistiska analīze}

Statistiskā analīze tika veikta, izmantojot IBM SPSS Statistics Version 20.0 statistikas programmatūras paketi (International Business Machines Corp., Armonk, New York, ASV). Ticamības intervāls (TI) tika noteikts, izmantojot Confidence Interval Analysis (CIA) programmatūru.

Uzsākot statistisko analīzi, datu normālsadalījums tika pārbaudīts, izmantojot Shapiro-Wilk testu. Aprakstošie dati tika izteikti kā vidējā vērtība \pm 
standarta novirze (SD), mediāna ar starpkvartīḷ diapazonu (IQR) vai relatīvās vērtības ar $95 \%$ ticamības intervālu (TI).

No aprakstošās statistikas metodēm tika izmantoti šãdi testi: aprakstošā un krusteniskās tabulas Pīrsona Hī-kvadrāta metode, divvariāciju korelācija kā Spīrmana rangu korelācijas koeficients, ne-parametriskās metodes kā MannaVitnija U-tests un Kruskala-Vallisa vienvirziena dispersijas rangu analīze. Post-hoc analīze Bonferoni modifikācijā tika izmantota, lai noteiktu atšķirības starp 3 vai vairāk grupām.

Izdzīvotības analīzei tika izmantota Kaplāna-Meijera analīze ar log-rank testu. Atšķirības tika uzskatītas par statistiski nozīmīgām, ja p vērtība $\leq 0,05$. 


\section{Rezultāti}

\subsection{Pētāmās grupas raksturojums}

\subsubsection{GBM raksturojums}

Pētījumā tika iekḷauti 146 pacienti ar GBM diagnozi, kas noteikta no 2009. līdz 2014. gadam. GBM bija diagnosticēta 75/146 (51,4 \%; $95 \%$ ticamības intervāls $(\mathrm{TI})=43,3-59,5)$ sievietēm un 71/146 (48,6 \%; $95 \%$ TI = 40,5-56,7) vīriešiem. Pacientu vecums bija no 34 līdz 89 gadiem. Vidējais pacientu vecums \pm standarta novirze $(\mathrm{SD})$ bija $62,0 \pm 11,2(95 \% \mathrm{TI}=60,2-63,8)$ gadi, mediānā vērtība - 62,0 (starpkvartiḷu diapazons, IQR = 18,0) gadi. Vīriešu vidējais vecums \pm SD bija 60,8 \pm 11,5 (95\% TI $=58,1-63,5)$ gadi; mediānais vecums bija 60,7 (IQR = 19,0) gadi. Sieviešu vidējais vecums \pm SD bija 63,1 $\pm 10,9$ $(95 \%$ TI = 60,7-65,7) gadi; mediānais vecums bija 65,0 (IQR = 17,0) gadi.

Visbiežāk sastopamā GBM lokalizācija bija pieres daiva ar 56/146 $(38,4 \%$; $95 \%$ TI $=30,5-46,3)$ gadījumiem, tad deniņu daiva $-41 / 146(28,1 \%$; $95 \% \mathrm{TI}=20,8-35,4)$ gadījumi, paura daiva $-21 / 146(14,1 \% ; 95 \%$ $\mathrm{TI}=8,5-19,7)$ gadījumi un pakauša daiva $-2 / 146(1,4 \%$; $95 \% \mathrm{TI}=0-3,3)$ gadījumi. 26/146 (17,8 \%; 95 \% TI = 11,6-24,0) no GBM plaši infiltrēja vairākas daivas vienā smadzeņu puslodē. 78/146 (53,4 \%; 95 \% TI = 45,3-61,5) no GBM lokalizējās labajā galvas smadzeṇu puslodē, bet 62/146 (42,5\%; 95 \% TI = 34,550,5) kreisajā puslodē. 6/146 (4,1 \%; $95 \%$ TI = 0,9-7,3) no GBM bija bilaterālas ar abu pieres daivu iesaisti. Multifokālas GBM konstatēja 16/146 (11,0 \%; 95 \% $\mathrm{TI}=5,9-16,1)$ gadījumos.

Audzēja maksimālais diametrs pēc magnētiskās rezonanses (MR) datiem bija no 1 līdz $9 \mathrm{~cm}$; vidējais izmērs $\pm \mathrm{SD}$ bija $5,1 \pm 1,4 \quad(95 \%$ TI - 4,85-5,36) cm; mediānais izmērs bija 5,1 (IQR = 2,0) cm. 101/123 (29,5\%; $95 \%$ TI = 21,4-37,6) gadījumos audzēja maksimālais diametrs bija lielāks par 4 
cm, bet 22/123 $(15,1 \%$; 95 \% TI = 8,8-21,4) gadījumos mazāks par 4 cm. MR dati nebija pieejami 23/146 (15,7\%; $95 \% \mathrm{TI}=9,8-21,6)$ GBM gadījumiem.

Visiem (146/146) GBM gadījumiem veikta audzēja ķirurǵiska rezekcija, pēc kuras daudzi pacienti saņēma adjuvantu terapiju - ķīmijterapiju ar temozolamīdu (TMZ) un radioterapiju. Dati par saņemto adjuvantu terapiju nebija pieejami 11/146 (7,5 \%; 95 \% TI = 4,3-12,9) GBM gadījumiem. Pārējie 135 GBM pacienti visbiežāk saņēmuši maksimāli iespējamo standartterapiju pēc ķirurğiskas audzēja rezekcijas, t. i., ķīmijterapiju ar TMZ, ko papildināja ar radioterapiju $-56 / 135(41,5 \%$; $95 \% \mathrm{TI}=33,5-49,9)$ gadījumos. Ķirurğisku ārstēšanu, kura sekoja tikai radioterapija bija saņēmuši 50/135 (37,0 \%; 95 \% $\mathrm{TI}=29,3-45,4)$ pacienti, savukārt 29/135 (21,4\%; $95 \%$ TI $=15,3-29,1)$ pacientiem bija veikta tikai ķirurğiska ārstēšana bez adjuvantas terapijas. Pacienti, kuri bija saṇēmuši maksimāli iespējamo standartterapiju ar TMZ, bija gados jaunāki, salīdzinot ar pacientiem, kuri saņēma tikai radioterapiju un ķirurğisku ārstēšanu (ANOVA, $\mathrm{p}<0,001$ ). Pacientu vidējais vecums dažādās ārstēšanas grupās bija šāds: kiirurǵiska ārstēšana + standartterapija ar TMZ un radioterapiju $-55,0(95 \%$ TI $=52,5-57,5)$ gadi; ķirurğiska ārstēšana + radioterapija - 65,9 (95\% TI $=62,9-68,7)$ gadi; tikai ķirurgíska ārstēšana 69,0 (95 \% TI = 65,3-72,7) gadi. Pacientu ārstēšanas grupās nebija saistības ar saņemto terapijas veidu un audzēja izmēru (Kruskal-Wallis H; $\mathrm{p}=0,708$ ).

\subsubsection{DA raksturojums}

Pētījumā tika iekḷauti 26 pacienti ar DA diagnozi, kas noteikta laika periodā no 2009. līdz 2014. gadam.

DA bija diagnosticēta $14 / 26(53,8 \%$; $95 \% \mathrm{TI}=34,6-72,7)$ sievietēm un 12/26 (46,2 \%; 95 \% TI = 27,0-65,4) vīriešiem. Pacientu vecums bija no 21 līdz 67 gadiem. Vidējais pacientu vecums \pm standarta novirze (SD) bija 37,5 $\pm 11,2$ $(95 \%$ TI = 33,0-42,0) gadi, mediānā vērtība - 35,5 (IQR = 19,0) gadi. Vīriešu 
vidējais vecums \pm SD bija 37,6 $\pm 12,3(95 \% \mathrm{TI}=29,8-45,5)$ gadi; mediānais vecums bija 34,0 (IQR = 17,0) gadi. Sieviešu vidējais vecums \pm SD bija 37,4 \pm $10,5(95 \%$ TI $=31,3-43,4)$ gadi; mediānais vecums bija 36,0 $(\mathrm{IQR}=20,0)$ gadi.

Visbiežāk sastopamā DA lokalizācija bija pieres daiva ar 13/26 (50\%; 95\% $\mathrm{TI}=30,8-69,2)$ gadījumiem, tad deniņu daiva $-6 / 26(23,1 \% ; 95 \%$ $\mathrm{TI}=6,9-39,3)$ gadījumi. 7/26 (26,9 \%; $95 \% \mathrm{TI}=9,9-43,9)$ DA gadījumos bija iesaistītas vairākas daivas. $14 / 26(53,8 \% ; 95 \%$ TI $=34,6-72,0)$ no DA lokalizējās labajā galvas smadzeņu puslodē, bet 12/26 (46,2\%; $95 \%$ $\mathrm{TI}=27,0-65,4)$ kreisajā puslodē.

Visas DA bija lieli audzēji, maksimālais diametrs pēc magnētiskās rezonanses (MR) datiem bija no 4,7 līdz 9,0 cm; vidējais izmērs bija 6,1 $\pm 0,9$ $(95 \% \mathrm{TI}=5,6-6,7) \mathrm{cm}$; mediānais izmērs $6,0(\mathrm{IQR}=1,0) \mathrm{cm}$. MR dati nebija pieejami 13/26 (50,0\%; $95 \% \mathrm{TI}=30,8-69,2)$ DA gadījumiem.

Visiem (26/26) DA gadījumiem veikta audzēja ķirurǵiska rezekcija, pēc kuras visi pacienti saṇēma adjuvantu radioterapiju.

\subsection{Morfologiskais raksturojums}

\subsubsection{GBM raksturojums}

Visām GBM diagnoze bija uzstādīta, vadoties pēc 2016 PVO CNS audzēju klasifikācijas, galvenie morfologiskie GBM kritēriji ir nekrožu klātbūtne (išēmiska un/vai pseidopalisadējoša tipa) un mikrovaskulāra proliferācija (skat. 2.1. attēlu). IDH1 mutācijas statuss tika noteikts imūnhistoḳīmiski ar anti- IDH1 $\mathrm{R} 132 \mathrm{H}$.

16/146 (10,9\%; $95 \%$ TI = 5,8-16,0) GBM gadījumos morfoloǵiski konstatēja vieglu, iniciālu mikrovaskulāru proliferāciju, taču nekrozes un izteikta šūnu atipija nepārprotami liecināja par GBM diagnozi. 130/146 (89,0 \%; 95 \% TI = 83,9-94,1) GBM gadījumos mikrovaskulāra proliferācija bija izteikta, bieži 
ar glomeruloīdu vaskulāru struktūru veidošanos. Lielākā daḷa no GBM bija ar klasisku morfologiju - 141/146 (96,6 \%; $95 \%$ TI = 93,7-99,5). 2/146 (1,4\%; $95 \%$ TI $=0-3,3)$ pacientiem bija arī gliosarkoma, kuru raksturo izteikta sarkomatoza morfolog̣ija ar vārpstveidīgām audzēja šūnām. 3/146 (2,1 \%; 95 \% $\mathrm{TI}=0-4,4)$ pacientiem bija diagnosticēta gigantšūnu jeb milzšūnu GBM, kuru pārsvarā veido ḷoti lielas, atipiskas audzēja šūnas. GBM morfologiiskās īpatnības parādītas 2.1. attēlā.
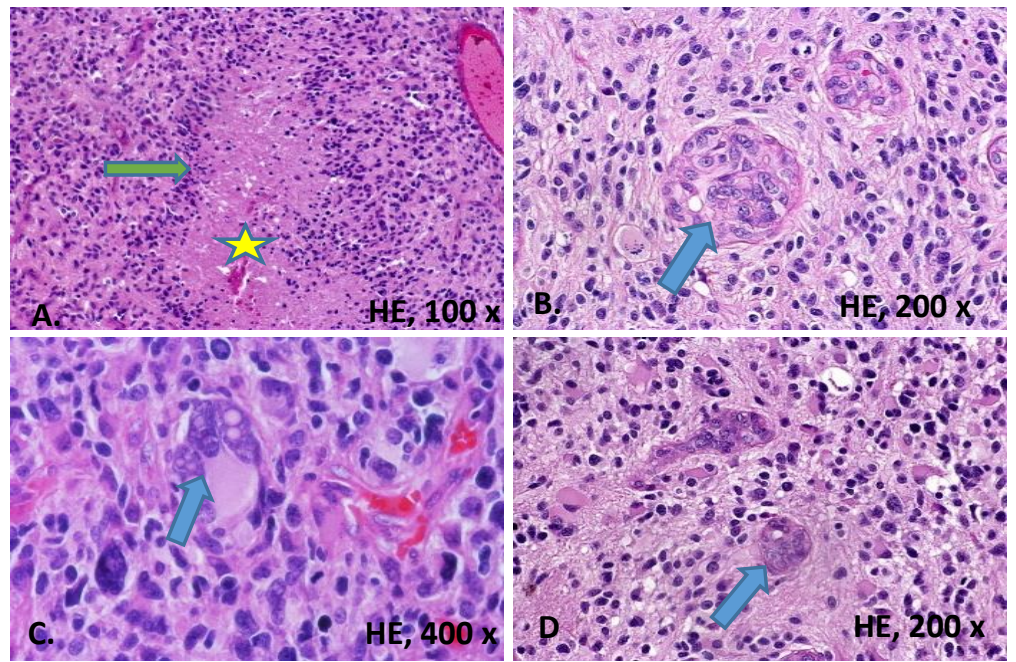

2.1. attēls. GBM morfolog̣ija: A, pseidopalisadējoša nekroze.

Pseidopalisāde parādīta ar zaḷo bultiṇu, nekroze ir centrā ar dzelteno zvaigznīti. B, izteikta glomeruloīda mikrovaskulāra proliferācija (bultiņa). C, izteikta šūnu atipija un gigantiskas atipiskas audzēja šūnas (bultiṇa). D, iniciāla, viegla mikrovaskulāra proliferācija (bultina)

Hematoksilīna un eozīna krāsojums (HE), attēla palielinājums $100 \times(\mathrm{A}), 200 \times(\mathrm{B}$ un D), $400 \times(\mathrm{C})$. 


\subsubsection{DA raksturojums}

Visām DA diagnoze bija uzstādīta pēc raksturīgām morfologiiskām īpatnībām, vadoties pēc 2016 PVO CNS audzēju klasifikācijas. Visas DA raksturoja viegla vai mērena celularitāte, lai gan 3/26 (11,5\%; $95 \%$ $\mathrm{TI}=0-23,7)$ konstatēja arī atsevišķus paaugstinātas celularitātes rajonus. Visos audzējos bija konstatētas retas mitozes - līdz 2 mitozēm uz 10 lielā palielinājuma redzes laukiem. Visās DA konstatēta viegla kodolu atipija, bet nebija konstatētas nekrozes vai mikrovaskulāra proliferācija. 2/26 (7,7 \%; 95 \% TI = 0-17,8) DA konstatēja izteikti palielinātu reaktīvu astrocītu - gemistocītu daudzumu. 12/26 $(46,1 \% ; 95 \%$ TI $=26,0-65,3)$ audzējiem konstatēja izteiktas mikrocistiskas izmainas. DA morfologiskās īpatnības parādītas 2.2. attēlā $(\mathrm{A}-\mathrm{D})$.
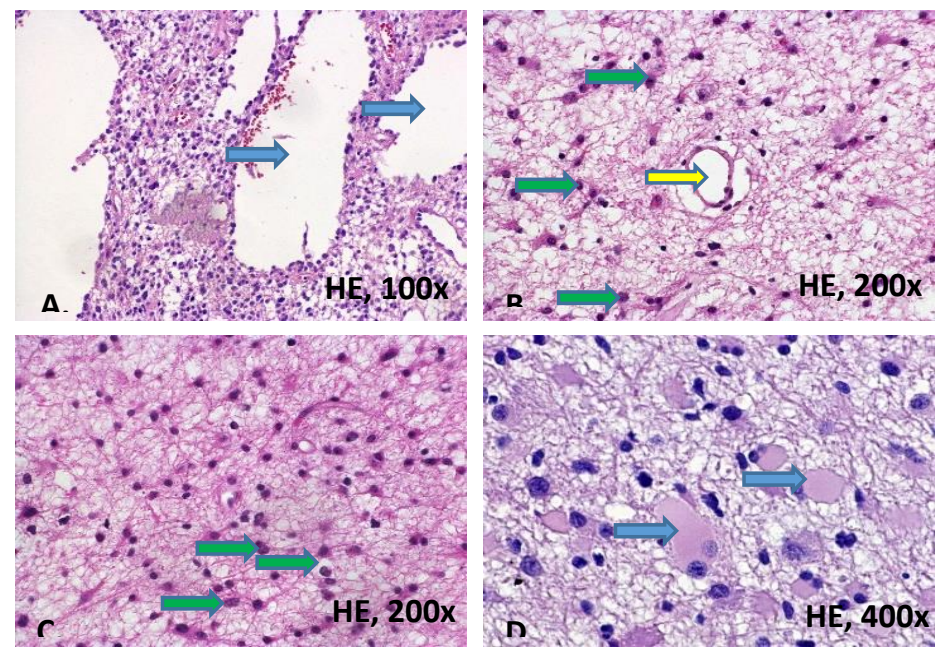

2.2. attēls. DA morfoloğija: A, mikrocistiskas izmaiņas (bultiṇas)

B, C, zema celularitāte, sīkas neoplastiskas šūnas, salīdzinoši monomorfiem kodoliem (zaḷās bultiṇas), asinsvads (dzeltena bultina). D, gemistocītiski astrocīti - lielas šūnas ar izteikti eozinofîlu citoplazmu (zilās bultiṇas)

Hematoksilīna un eozīna krāsojums (HE), attēla palielinājums 100× (A), $200 \times$ (B un C), $400 \times$ (D). 


\subsection{GBM un DA imūnhistoḳīmiskais profils}

GBM un DA audos tika pētīta šāda imūnhistoḳīmisku marķieru ekspresija: Ki-67, p53, p21, p27, CD44, PDGFRA, IDH1 R132H, CD34. Imūnhistoḳīmisku marķieru ekspresijas profils GBM un DA attēlots 2.1. tabulā. Imūnhistoḳīmisko marḳieru ekspresija vizuāli parādīta 2.3. attēlā.

Šūnas cikla markiieru izvērtējums uzsākts ar proliferācijas aktivitātes analīzi kā vienu no galvenajām audzēju pamatīpašībām. Proliferācijas frakcija GBM bija daudz augstāka, salīdzinot ar DA, - atbilstoši 44,4\% (95\% $\mathrm{TI}=41,1-47,6]$ un $6,4 \%[95 \% \mathrm{TI}=4,7-8,0)$.

Aberanta p53 proteīna ekspresija bija ḷoti variabla abās gliomu grupās, tā variēja no pilnīgas imunonegativitātes $(0 \%)$ līdz izteiktai ekspresijai gandrīz visās audzēja šūnās (99 \%). Gadījumu skaits ar jebkuru p53 proteīna ekspresijas līmeni (>1 \%) bija ḷoti līdzīgs gan GBM, gan DA - atbilstoši 87,3 \% (95 \% TI = 81,5-93,1) un 87,5 \% (95 \% TI = 74,3-100). Savukārt augstu p53 ekspresijas līmeni (>50 \%) procentuāli vairāk konstatēja DA - 50,0 \% (95\% TI = 30,869,2), salīdzinot ar GBM - 31,7 \% (95 \% TI = 23,6-39,8). Salīdzinot vidējo p53 ekspresijas līmeni (2.1. tabula), nekonstatēja statistiski ticamu ekspresijas atšķirību starp GBM un DA ( $\mathrm{p}=0,416)$. N̦emot vērā ekspresijas robežvērtību (10\%), p53 ekspresija tika konstatēta 64,3\% (95\% TI = 55,6-72,1) GBM gadījumu, pretstatā $75,0 \% \quad(95 \% \quad$ TI $=55,1-88)$ DA gadījumu.

p21 ekspresija GBM audos bija statistiski ticami augstāka nekā DA, t. i., $21,2 \%(95 \% \mathrm{TI}=18,7-23,6)$ pret 6,9\% (95\% TI = 2,4-11,4). N̦emot vērā ekspresijas robežvērtību (20\%), augsta p21 ekspresija konstatēta 49,3\% (95\% $\mathrm{TI}=41,3-57,4)$ GBM gadījumu un tikai $15 \%(95 \%$ TI $=5,2-36,0)$ DA gadījumu.

Proteīna p27 ekspresija tika novērota visos gadījumos, tomēr vidējais p27 pozitîvu šunu skaits bija nozīmīgi zemāks GBM gadījumos $(69,7 \%$; $95 \%$ 
TI $=65,8-73,7)$ nekā DA $(86,6$ \%; 95 \% TI = 81,6-91,7). N̦emot vērā ekspresijas robežvērtību (70 \%), augsta p27 ekspresija konstatēta 60,1 \% (95 \% TI = 50,968,7) GBM gadījumu, salīdzinot ar 86,9 \% (95 \% TI = 67,8-95,4) DA.

CD44 proteīna ekspresija bija ievērojami augstāka GBM (74,1 \%; 95 \% $\mathrm{TI}=69,6-78,7)$, salīdzinot ar DA (13,5\%; $95 \% \mathrm{TI}=7,7-19,2)$. Augsts CD44 ekspresijas līmenis (>50\% neoplastisku šūnu) konstatēts 81,5\% (95\% $\mathrm{TI}=74,6-87,4)$ GBM gadījumu, salīdzinot tikai ar vienu DA gadījumu, kuram CD44 ekspresija sasniedza šo līmeni. GBM galvenokārt dominēja intensīva, difūza, membranoza CD44 ekspresija. Savukārt CD44 ekspresija DA bija maz izteikta un lielākoties citoplazmiska rakstura, daudzajos sazarotajos astrocītu izaugumos, veidojot smalku, sazarotu, zemas intensitātes CD44 imūnreaktivitātes tīklojumu. Turklāt visās DA konstatēja arī atsevišķus augstākas intensitātes CD44 ekspresijas perēkḷus ar vismaz vidēju CD44 ekspresijas intensitāti.

PDGFRA ekspresija bija ievērojami augstāka DA, salīdzinot ar GBM (p < 0,001). Tādējādi augstu PDGFRA ekspresiju (>50\%) konstatēja 6,2 \% $(95 \% \mathrm{TI}=5,0-10,6)$ GBM gadījumu un $52,6 \%(95 \% \mathrm{TI}=30,1-75,0)$ DA gadījumu. Lielākajā daḷā gadījumu novēroja citoplazmisku un membranozu PDGFRA ekspresiju neoplastiskajās šūnās, taču atsevišşos gadījumos novērota arī nukleāra ekspresija.

Mutanta IDH1 R132H proteīna ekspresija bija konstatēta 3,4 \% (95\% $\mathrm{TI}=0,5-6,3)$ GBM, salīdzinot ar 76,9\% (95\% TI $=60,7-93,1)$ DA. Visos gadījumos konstatēta intensīva nukleāra ekspresija. Starp IDH1 pozitīvajiem GBM gadījumiem tikai vienā gadījumā morfologiski konstatēts zemākas malignitātes pakāpes komponents, morfologiski apstiprinot sekundāru GBM, kas attīstījusies zemas anaplāzijas pakāpes gliomas malignas transformācijas rezultātā. Visos IDH1 R132H pozitīvu GBM ( $\mathrm{n}=5)$ gadījumos ne radiologiski, 
ne klīniski nebija atrodama informācija, kas liecinātu par iepriekš eksistējošu zemas malignitātes pakāpes gliomu.

Mikrovaskularizācijas blīvums (MVB) tika izvērtēts, pielietojot imūnhistoḳīmisko vizualizāciju ar CD34. GBM audos MVB diapazons bija no 6 līdz 130 vaskulārām struktūrām vienā augsta palielinājuma redzes laukā, vidējais MVB \pm SD bija 40,7 \pm 25,4 (95\% TI = 35,8-45,6) un mediānā vērtība - 35,0 (IQR = 29,0). DA audos MVB diapazons bija no 4 līdz 49 vaskulārām struktūrām vienā augsta palielinājuma redzes laukā, vidējais MVB \pm SD bija 18,1 $\pm 12,1(95 \%$ TI = 12,9-23,3) un mediānā vērtība $-13,0(\mathrm{IQR}=16,0)$. Tādā veidā GBM audos MVB bija statistiski ticami lielāks salīdzinot ar DA $(\mathrm{p}<0,001)$.

2.1. tabula

Imūnhistoḳīmisko marḳieru ekspresijas raksturojums GBM un DA

\begin{tabular}{|c|c|c|}
\hline Parametrs & GBM & DA \\
\hline \multicolumn{3}{|l|}{ Ki-67 } \\
\hline Izmeklēto gadījumu skaits & 126 & 24 \\
\hline Vidējais daudzums \pm SD; 95 \% TI & $\begin{array}{l}44,4 \% \pm 18,5 \\
41,1-47,6\end{array}$ & $\begin{array}{l}6,4 \% \pm 3,9 \\
4,7-8,0\end{array}$ \\
\hline Mediānais daudzums; IQR & 41,$0 ; 24$ & 5,$5 ; 6$ \\
\hline $\begin{array}{l}\text { Augsta Ki-67 ekspresija; Nr; \%; } \\
95 \% \text { TI (ekspresijas robežvērtība } 25 \% \text { ) }\end{array}$ & $\begin{array}{l}111 ; 88,1 \\
81,2-92,6\end{array}$ & $\begin{array}{l}0 ; 0 \\
0-10,3\end{array}$ \\
\hline $\begin{array}{l}\text { Augsta Ki-67 ekspresija; Nr; \%; } \\
95 \% \text { TI (ekspresijas robežvērtība } 41 \%)\end{array}$ & $\begin{array}{l}61 ; 48,4 \\
39,8-57,0\end{array}$ & $\begin{array}{l}0 ; 0 \\
0,0-13,8\end{array}$ \\
\hline $\begin{array}{l}\text { Augsta Ki-67 ekspresija; Nr; \%; } \\
95 \% \text { TI (ekspresijas robežvērtība } 3 \% \text { ) }\end{array}$ & $\begin{array}{l}126 ; 100 \% \\
97,0-100\end{array}$ & $\begin{array}{l}16 ; 66,7 \\
46,7-82,0\end{array}$ \\
\hline $\begin{array}{l}\text { Augsta Ki-67 ekspresija; Nr; \%; } \\
95 \% \text { TI (ekspresijas robežverrtiba } 5 \% \text { ) }\end{array}$ & $\begin{array}{l}126 ; 100 \% \\
97,0-100\end{array}$ & $\begin{array}{l}12 ; 50,0 \\
31,4-68,5 \\
\end{array}$ \\
\hline \multicolumn{3}{|l|}{ 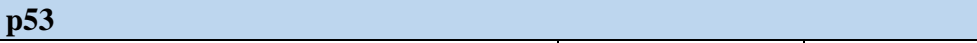 } \\
\hline Izmeklēto gadījumu skaits & 126 & 24 \\
\hline Vidējais daudzums \pm SD; 95 \% TI & $\begin{array}{l}35,3 \pm 37,6 \\
28,7-42,0\end{array}$ & $\begin{array}{l}43,4 \pm 31,7 \\
30,0-56,8\end{array}$ \\
\hline
\end{tabular}


2.1. tabulas turpinājums

\begin{tabular}{|c|c|c|}
\hline Parametrs & GBM & DA \\
\hline Mediānais daudzums; IQR & 15,$0 ; 71$ & 52,$0 ; 63$ \\
\hline 0-5 \% p53 pozitīvo šūnu; $\mathrm{Nr} ; \%$; 95\% TI & $\begin{array}{l}30 ; 23,8 \\
17,2-31,9\end{array}$ & $\begin{array}{l}6 ; 25,0 \\
12,0-44,9\end{array}$ \\
\hline 6-10\% p53 pozitīvo šūnu; Nr; \%; 95\% TI & $\begin{array}{l}25 ; 19,8 \\
13,8-27,6\end{array}$ & $\begin{array}{l}0 ; 0 \\
0-13,8\end{array}$ \\
\hline 11-50 \% p53 pozitīvo šūnu; Nr; \%; 95 \% TI & $\begin{array}{l}31 ; 24,6 \\
17,9-33,2\end{array}$ & $\begin{array}{l}6 ; 25,0 \\
12,0-44,9\end{array}$ \\
\hline$>50$ \% p53 pozitīvo šūnu; Nr; \%; 95 \% TI & $\begin{array}{l}40 ; 31,7 \\
24,2-40,3\end{array}$ & $\begin{array}{l}12 ; 50,0 \\
31,4-68,6\end{array}$ \\
\hline $\begin{array}{l}\text { Augsta p53 ekspresija; Nr; \%; } \\
95 \% \text { TI (ekspresijas robežvērtība } 10 \%)\end{array}$ & $\begin{array}{l}81 ; 64,3 \\
55,6-72,1\end{array}$ & $\begin{array}{l}18 ; 75 \\
55,1-88,0\end{array}$ \\
\hline \multicolumn{3}{|l|}{ p53 } \\
\hline $\begin{array}{l}\text { Augsta p53 ekspresija; Nr; \%; } \\
\text { 95\% TI (ekspresijas robežvērtība } 15 \% \text { ) }\end{array}$ & $\begin{array}{l}67 ; 53,2 \\
44,5-53,2\end{array}$ & $\begin{array}{l}17 ; 70,8 \\
50,8-85,1\end{array}$ \\
\hline $\begin{array}{l}\text { Augsta p53 ekspresija; Nr; \%; } \\
95 \% \text { TI (ekspresijas robežvērtība 52\%) }\end{array}$ & $\begin{array}{l}39 ; 30,9 \\
23,5-39,5\end{array}$ & $\begin{array}{l}12 ; 50 \% \\
31,4-68,6\end{array}$ \\
\hline \multicolumn{3}{|l|}{ CD44 } \\
\hline Izmeklēto gadījumu skaits & 146 & 26 \\
\hline Vidējais daudzums \pm SD; 95 \% TI & $\begin{array}{l}74,1 \pm 27,8 \\
69,6-78,7\end{array}$ & $\begin{array}{l}13,5 \pm 14,3 \\
7,7-19,2\end{array}$ \\
\hline Mediānais daudzums; IQR & 86,$5 ; 36$ & 8,$5 ; 15$ \\
\hline $\begin{array}{l}\text { Augsta CD44 ekspresija; Nr; \%; } \\
95 \% \text { TI (ekspresijas robežvērtība } 50 \% \text { ) }\end{array}$ & $\begin{array}{l}119 ; 81,5 \\
74,4-86,9\end{array}$ & $\begin{array}{l}0 ; 0 \\
0-12,0\end{array}$ \\
\hline $\begin{array}{l}\text { Augsta CD44 ekspresija; Nr; \%; } \\
\text { 95\% TI (ekspresijas robežvērtība 86\%) }\end{array}$ & $\begin{array}{l}75 ; 51,4 \\
43,3-59,3\end{array}$ & $\begin{array}{l}0 ; 0 \\
0-12,0\end{array}$ \\
\hline $\begin{array}{l}\text { Augsta CD44 ekspresija; Nr; \%; } \\
95 \% \text { TI (ekspresijas robežvērtība } 8 \% \text { ) }\end{array}$ & $\begin{array}{l}144 ; 98,6 \\
95,1-99,6\end{array}$ & $\begin{array}{l}14 ; 53,8 \\
35,4-71,2\end{array}$ \\
\hline \multicolumn{3}{|l|}{ p21 } \\
\hline Izmeklēto gadījumu skaits & 146 & 20 \\
\hline Videjais daudzums \pm SD; $95 \%$ TI & $\begin{array}{l}21,2 \pm 15,0 \\
18,7-23,6\end{array}$ & $\begin{array}{l}6,9 \pm 9,5 \\
2,4-11,4 \\
\end{array}$ \\
\hline Mediānais daudzums; IQR & 19,$0 ; 19$ & 2,$5 ; 7$ \\
\hline $\begin{array}{l}\text { Augsta p21 ekspresija; Nr; \%; } \\
95 \% \text { TI (ekspresijas robežvērtība } 20 \% \text { ) }\end{array}$ & $\begin{array}{l}72 ; 49,3 \\
41,3-57,4\end{array}$ & $\begin{array}{l}3 ; 15 \\
5,2-36,0\end{array}$ \\
\hline $\begin{array}{l}\text { Augsta p21 ekspresija; Nr; \%; } \\
95 \% \text { TI (ekspresijas robežvērtība 2,5\%) }\end{array}$ & $\begin{array}{l}145 ; 99,3 \\
96,2-99,9\end{array}$ & $\begin{array}{l}12 ; 60 \\
38,6-78,1\end{array}$ \\
\hline \multicolumn{3}{|l|}{ p27 } \\
\hline Izmeklēto gadījumu skaits & 113 & 23 \\
\hline
\end{tabular}


2.1. tabulas turpinājums

\begin{tabular}{|c|c|c|}
\hline Parametrs & GBM & DA \\
\hline Vidējais daudzums \pm SD; $95 \%$ TI & $\begin{array}{l}69,7 \pm 21,2 \\
65,8-73,7\end{array}$ & $\begin{array}{l}86,6 \pm 11,6 \\
81,6-91,7\end{array}$ \\
\hline Mediānais daudzums; IQR & $74 ; 31$ & $92 ; 17$ \\
\hline $\begin{array}{l}\text { Augsta p27 ekspresija; Nr; \%; } \\
95 \% \text { TI (ekspresijas robežvērtība 70\%) }\end{array}$ & $\begin{array}{l}68 ; 60,1 \\
50,9-68,7\end{array}$ & $\begin{array}{l}20 ; 86,9 \\
67,8-95,4\end{array}$ \\
\hline $\begin{array}{l}\text { Augsta p27 ekspresija; Nr; \%; } \\
95 \% \text { TI (ekspresijas robežvērtība 92 \%) }\end{array}$ & $\begin{array}{l}11 ; 9,7 \\
5,2-17,1\end{array}$ & $\begin{array}{l}12 ; 52,2 \\
32,9-70,7\end{array}$ \\
\hline \multicolumn{3}{|l|}{ PDGFRA } \\
\hline Izmeklēto gadījumu skaits & 146 & 20 \\
\hline Vidējais daudzums \pm SD; $95 \%$ TI & $\begin{array}{l}7,9 \pm 17,3 \\
5,0-10,7\end{array}$ & $\begin{array}{l}42,3 \pm 35,5 \\
25,7-59,0\end{array}$ \\
\hline Mediānais daudzums; IQR & 1,$0 ; 4$ & 42,$0 ; 68$ \\
\hline $\begin{array}{l}0-10 \% \text { PDGFRA pozitīvo šūnu; Nr; \%; } \\
95 \% \text { TI }\end{array}$ & $\begin{array}{l}118 ; 80,8 \\
74,4-87,2\end{array}$ & $\begin{array}{l}5 ; 26,3 \\
6,5-46,1\end{array}$ \\
\hline \multicolumn{3}{|l|}{ PDGFRA } \\
\hline $\begin{array}{l}\text { 10-50 \% PDGFRA pozitīvo šūnu; Nr; \% } \\
95 \% \text { TI }\end{array}$ & $\begin{array}{l}19 ; 13,0 \\
7,5-18,5\end{array}$ & $\begin{array}{l}4 ; 21,1 \\
2,7-39,4\end{array}$ \\
\hline $\begin{array}{l}>50 \% \text { PDGFRA pozitīvo šūnu; Nr; \% } \\
95 \% \text { TI }\end{array}$ & $\begin{array}{l}9 ; 6,2 \\
2,3-10,1\end{array}$ & $\begin{array}{l}10 ; 52,6 \\
30,1-75,0\end{array}$ \\
\hline $\begin{array}{l}\text { Augsta PDGFRA ekspresija; Nr; \%; } \\
95 \% \text { TI (ekspresijas robežvērtība 50\%) }\end{array}$ & $\begin{array}{l}9 ; 6,1 \\
3,2-11,3\end{array}$ & $\begin{array}{l}10 ; 50 \\
29,9-70,1\end{array}$ \\
\hline $\begin{array}{l}\text { Augsta PDGFRA ekspresija; Nr; \%; } \\
95 \% \text { TI (ekspresijas robežvērtība 1\%) }\end{array}$ & $\begin{array}{l}130 ; 89,0 \\
82,9-93,1\end{array}$ & $\begin{array}{l}20 ; 100 \\
83,9-100\end{array}$ \\
\hline $\begin{array}{l}\text { Augsta PDGFRA ekspresija; Nr; \%; } \\
95 \% \text { TI (ekspresijas robežvērtība 42\%) }\end{array}$ & $\begin{array}{l}9 ; 6,2 \\
3,2-11,2\end{array}$ & $\begin{array}{l}10 ; 50 \\
29,9-70,1\end{array}$ \\
\hline \multicolumn{3}{|l|}{ IDH1 R132H } \\
\hline Izmeklēto gadījumu skaits & 146 & 26 \\
\hline $\begin{array}{l}\text { Negatīvs } \\
(\mathrm{Nr} ; \% ; 95 \% \mathrm{TI})\end{array}$ & $\begin{array}{l}141 ; 96,6 \\
93,7-99,5\end{array}$ & $\begin{array}{l}6 ; 23,1 \\
6,9-39,3\end{array}$ \\
\hline $\begin{array}{l}\text { Pozitīvs } \\
\text { (Nr; \%; } 95 \% \text { TI) }\end{array}$ & $\begin{array}{l}5 ; 3,4 \\
0,5-6,3\end{array}$ & $\begin{array}{l}20 ; 76,9 \\
60,7-93,1\end{array}$ \\
\hline \multicolumn{3}{|l|}{ MVB (CD34) } \\
\hline Izmeklēto gadījumu skaits & 107 & 23 \\
\hline Vidējais daudzums \pm SD; $95 \%$ TI & $\begin{array}{l}40,7 \pm 25,4 \\
35,8-45,6\end{array}$ & $\begin{array}{l}18,1 \pm 12,1 \\
12,9-23,3\end{array}$ \\
\hline Mediānais daudzums; IQR & 35,$0 ; 29$ & 13,$0 ; 16$ \\
\hline $\begin{array}{l}\text { Augsts MVB; Nr; \%; } \\
95 \% \text { TI (ekspresijas robežvērtība } 35 \% \text { ) }\end{array}$ & $\begin{array}{l}55,0 ; 51,4 \\
42,0-60,7\end{array}$ & $\begin{array}{l}3 ; 13,0 \\
4,5-32,1\end{array}$ \\
\hline
\end{tabular}




\begin{tabular}{|l|l|l|}
\hline \multicolumn{1}{|c|}{ Parametrs } & \multicolumn{1}{|c|}{ GBM } & \multicolumn{1}{c|}{ DA } \\
\hline Augsts MVB; Nr; \%; & $98 ; 91,6$ & $13 ; 56,5$ \\
95\% TI (ekspresijas robežvērtība 13\%) & $84,8-95,5$ & $36,8-74,4$ \\
\hline
\end{tabular}

Sā̄sinājumi tabulā: GBM, glioblastoma; DA, difūza astrocitoma; MVB, mikrovaskularizācijas blīvums; $\mathrm{Nr}$, skaits; TI, ticamības intervāls; SD, standarta novirze; IQR, starpkvartiḷu intervāls.
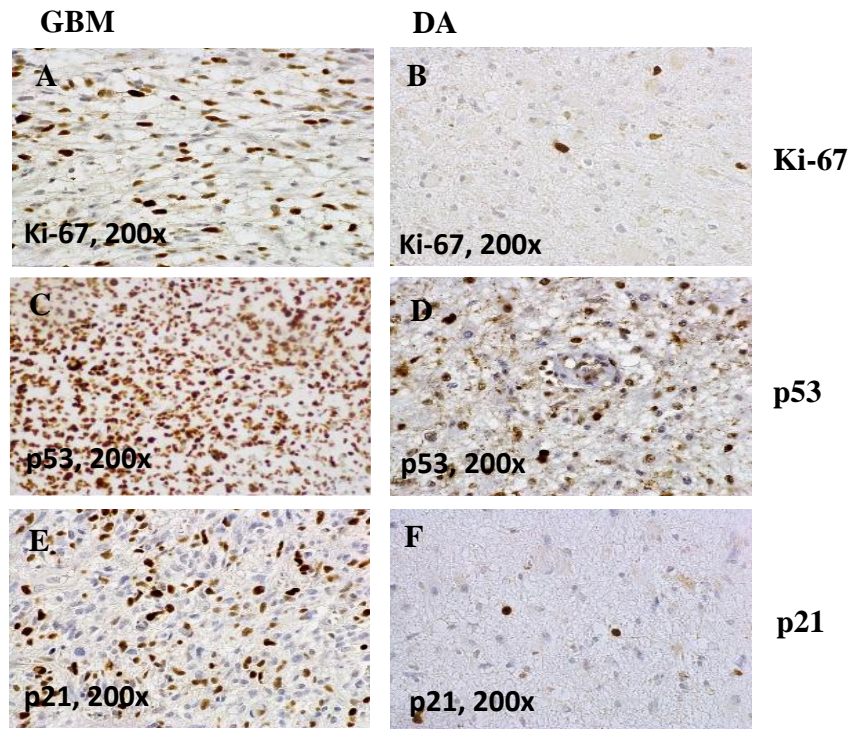

Ki-67
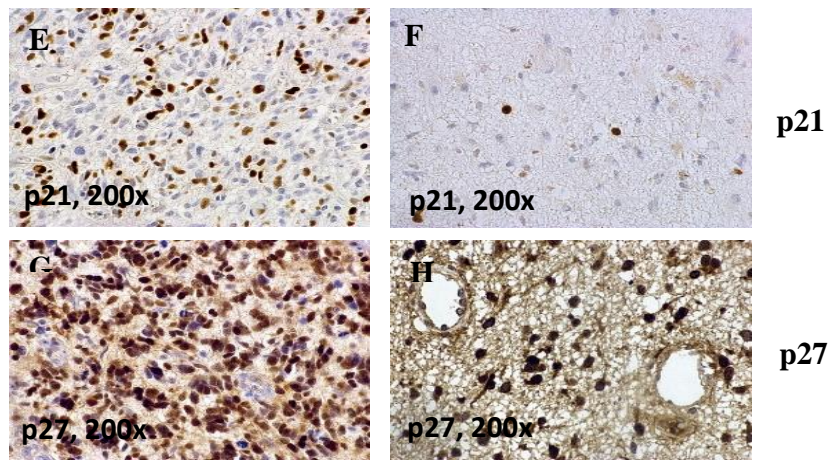

\section{p27}
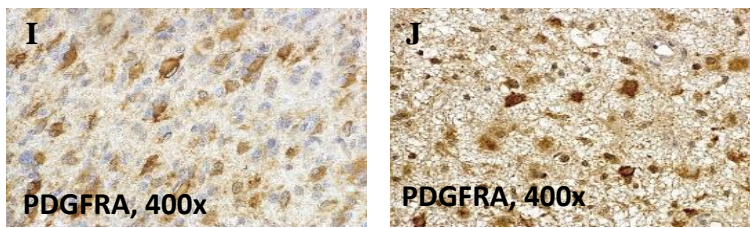

PDGFRA 
GBM
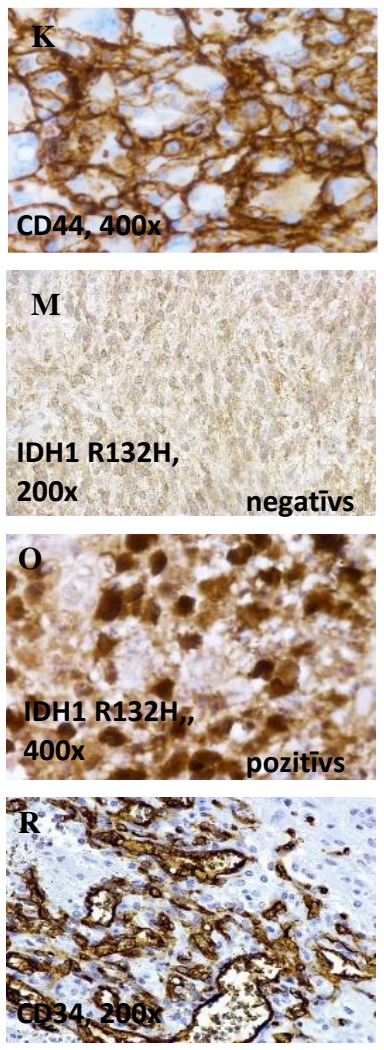

DA

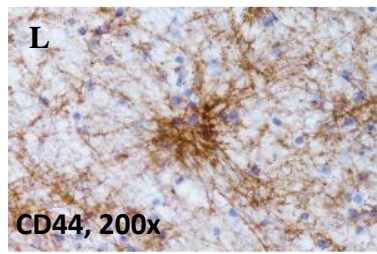

CD44

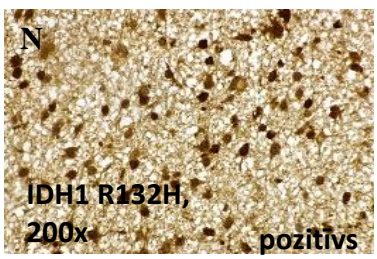

IDH1 R132H
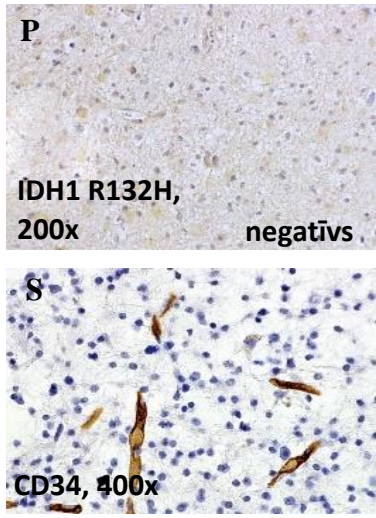

IDH1 R132H

MVB (CD34)

\section{3. attēls. Imūnhistoḳīmiska vizualizācija izmeklētajiem markieriem GBM un DA}

A un B, Ki-67 proliferācijas frakcija: izteikti paaugstināta proliferācija GBM (A) un zema proliferācija DA (B). C un D, p53 proteīna nukleāra ekspresija: C, GBM; D, DA.

E un F, p21 proteīna nukleāra ekspresija: E, GBM; F, DA. G un H, nukleāra p27 ekspresija: G, GBM; H, DA. I un J, citoplazmiska PDGFRA ekspresija: I, GBM; J, DA. K un L, CD44 ekspresija: K, GBM, intensīva membranoza ekspresija; L, DA, vāja, maz izteikta ekspresija neoplastisku šūnu fibrilārajos izaugumos, kā arī intensī̄ākas ekspresijas apvidus (bultina). M-P, IDH1 R132H mutācijas produkta ekspresija: M, IDH1 R132H negatīvs primārā GBM; O, IDH1 R132H pozit̄̄va ekspresija sekundārāā GBM; N, IDH1 R132H pozit̄ivs DA; P, IDH1 R132H negatīvs DA. K un S, MVB izvērtējums (CD34): K, GBM; S, DA. 


\subsection{Asociācijas un korelācijas starp klīniskajiem un imūnhistokī̄miskajiem parametriem}

\subsubsection{GBM raksturojums}

Pētījumā netika konstatētas statistiski nozīmīgas atšķirības starp imūnhistoḳīmisko marķieru ekspresiju un pacientu vecumu. Izmantojot MannaVitnija U testu, konstatēta tendence biežākai sekundāru GBM (IDH1 R132H pozitīvu) attīstībai gados jaunākiem pacientiem $(\mathrm{z}=-1,632 ; \mathrm{p}=0,060)$.

Statistiski ticama atšķirība konstatēta starp pacienta dzimumu un CD44 ekspresiju GBM, kas norāda, ka sieviešu grupā CD44 ekspresija ir augstāka (Manna-Vitnija U tests; $\mathrm{z}=-2,224 ; \mathrm{p}=0,026)$. Vāja, negatīva korelācija konstatēta starp CD44 un GBM izmēru $\left(\mathrm{r}_{\mathrm{s}}=-0,314 ; \mathrm{p}<0,001\right)$.

Analizējot šo saistību starp GBM izmēru un CD44 ekspresiju, kurā izmantots Manna-Vitnija U tests, arī konstatē augstākus CD44 ekspresijas rādītājus mazāka izmēra audzējos $(<4 \mathrm{~cm})(\mathrm{z}=-2,364 ; \mathrm{p}=0,018)$. CD44 ekspresijas imūnhistoķīmiska vizualizācija parādīta 2.4. attēlā (A, B).

Izmantojot Manna-Vitnija $U$ testu, konstatēta tendence nedaudz zemākiem Ki-67 proliferācijas indeksiem pacientiem vīriešu grupā $(z=-1,913$; $\mathrm{p}=0,056)$. Konstatēta arī vāja, bet statistiski ticama pozitīva korelācija starp Ki-67 un audzēja maksimālo diametru $\left(\mathrm{r}_{\mathrm{s}}=0,243 ; \mathrm{p}=0,013\right)$.

Ki-67 proliferācijas imūnhistoḳīmiska vizualizācija parādīta 2.5. attēlā.

Ļoti vāja, negatīva korelācija tika atrasta starp p21 ekspresiju un audzēja maksimālo diametru $\left(\mathrm{r}_{\mathrm{s}}=-0,181 ; \mathrm{p}=0,045\right) . \mathrm{Ka}$ arī, izmantojot Manna-Vitnija $\mathrm{U}$ testu, konstatēja augstāku p21 ekspresiju mazāka izmēra audzējos $(<4 \mathrm{~cm})(\mathrm{z}=-2,460 ; \mathrm{p}=0,014)$.

Statistiski ticamas p27 proteīna ekspresija atšķirības konstatēja attiecībā uz dzimumu un multifokalitāti. Tādējādi augstāka p27 proteīna ekspresija konstatēta vīriešu grupā (Manna-Vitnija $U$ testu; $z=-2,174 ; p=0,030$ ) un 
multifokālās GBM (Manna-Vitnija $\mathrm{U}$ testu; $\mathrm{z}=-2,1 ; \mathrm{p}=0,037$ ). p27 proteīna ekspresijas imūnhistoķīmiska vizualizācija parādīta 2.6. attēlā.

PDGFRA ekspresijas vidējiem rangiem konstatēta tendence uz augstāku ekspresiju multifokālās GBM (Manna-Vitnija U tests; $\mathrm{z}=-1,9 ; \mathrm{p}=0,049$ ). PDGFRA ekspresijas imūnhistoḳīmiska vizualizācija parādīta 2.7. attēlā.
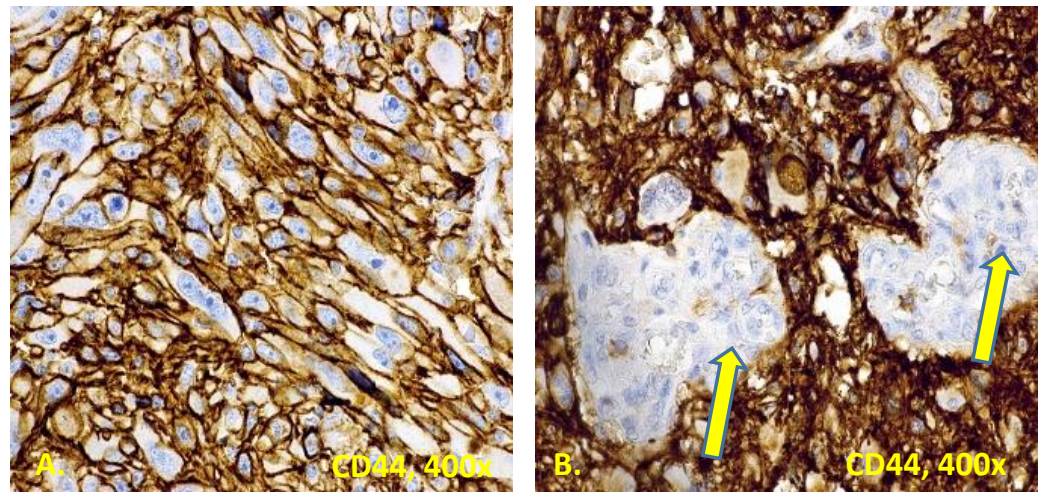

2.4. attēls. Intensīva membranoza CD44 ekspresija GBM. Izteikta mikrovaskulāra proliferācija, endotēlija šūnas negatīvas ar CD44 (iekšējā negatīvā kontrole) (bultiņas), anti-CD44 Attēla palielinājums $400 x$

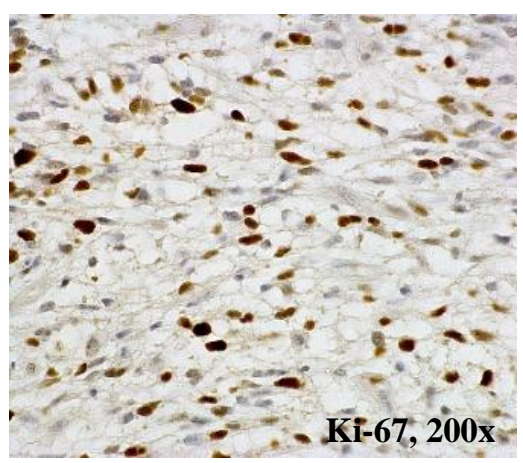

2.5. attēls. Ki-67 proliferācijas frakcija GBM, MIB-1 Attēla palielinājums 200×.

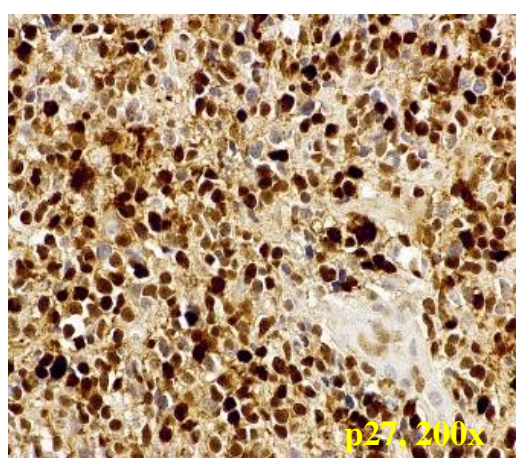

2.6. attēls. Nukleāra p27 ekspresija GBM, anti-p27

Attēla palielinājums $200 \times$. 

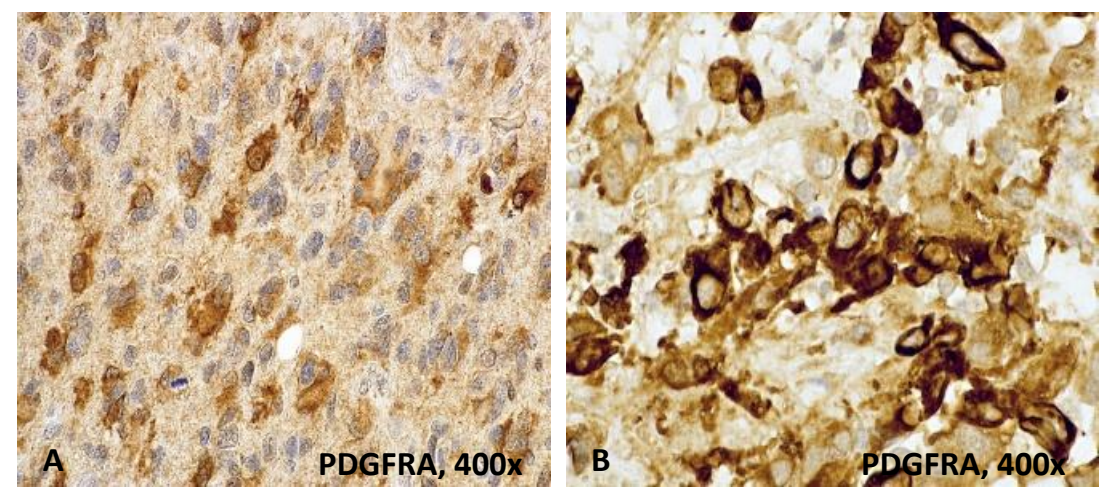

\section{7. attēls. Membranoza un citoplazmiska PDGFRA ekspresija GBM, anti-PDGFRA}

Attēla palielinājums 400×.

\subsubsection{DA raksturojums}

Izmantojot Manna-Vitnija U testu, tika konstatēta statistiski ticama Ki-67 ekspresijas atšķirība starp dzimumiem. Tādējādi Ki-67 ekspresijas vidējie rangi bija statistiski ticami augstāki vīriešu grupā $(\mathrm{z}=-2,201 ; \mathrm{p}=0,010)$.

Vidēji stipra korelācija tika konstatēta starp p27 ekspresiju un pacientu vecumu $\left(\mathrm{r}_{\mathrm{s}}=0,519 ; \mathrm{p}=0,011\right)$.

Ki-67 proliferācijas frakcijas un p27 ekspresijas imūnhistoḳimiska vizualizācija DA parādīta 2.8. un 2.9. attēlā.

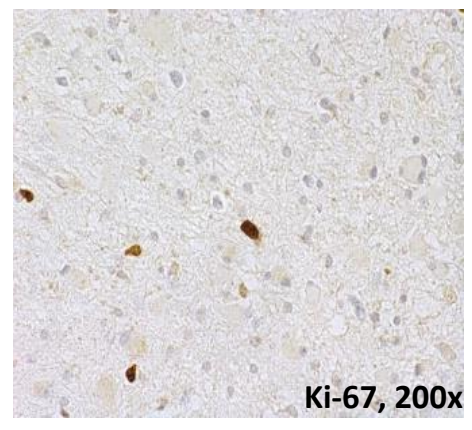

2.8. attēls. Ki-67 proliferācijas frakcija DA, MIB-1 Attēla palielinājums 200×.

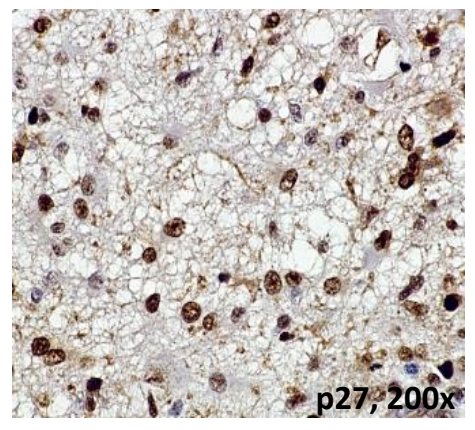

2.9. attēls. Nukleāra p27 ekspresija DA, anti-p27 Attēla palielinājums $200 \times$. 


\subsection{Asociācijas un korelācijas starp imūnhistoķīmiskajiem parametriem}

\subsubsection{GBM raksturojums}

p53 proteīna ekspresija uzrādīja ḷoti vāju, bet statistiski ticamu, pozitīvu korelāciju ar Ki-67 proliferācijas frakciju $\left(\mathrm{r}_{\mathrm{s}}=0,196 ; \mathrm{p}=0,027\right)$, un arī PDGFRA $\left(\mathrm{r}_{\mathrm{s}}=0,181 ; \mathrm{p}=0,043\right)$.Vāja pozitīva korelācija konstatēta arī starp p53 un MVB $\left(\mathrm{r}_{\mathrm{s}}=0,228 ; \mathrm{p}=0,031\right)$ Ki-67 proliferācijas rādītājiem piemita tendence uz ḷoti vāju, negatīvu korelāciju ar p27 $\left(\mathrm{r}_{\mathrm{s}}=0,199 ; \mathrm{p}=0,055\right)$.

Izmantojot Manna-Vitnija U testu, tika konstatēta ievērojami augstāka p53 proteīna ekspresija sekundārās GBM (IDH1 R132H pozitīvas) $(z=-3,555$; p = 0,001). Izvērsts asociāciju un korelāciju spektrs starp analizētajiem imūnhistoḳīmisko marķieriem GBM ir apkopots 2.2. tabulā.

2.2. tabula

\section{Savstarpējās korelācijas un asociācijas starp imūnhistoḳīmiskajiem marḳieriem GBM, izmantojot Spīrmana korelācijas analīzi un Manna-Vitnija U testu}

\begin{tabular}{|l|l|l|l|l|l|l|l|}
\hline Parametrs & Ki-67 & $\mathbf{p 5 3}$ & CD44 & PDGFRA & P21 & P27 & MVD \\
\hline Ki-67 & NP & $\mathbf{0 , 1 9 6}$ & $-0,162$ & 0,098 & $-0,060$ & $\mathbf{- 0 , 1 9 9}$ & $-0,038$ \\
& & $\mathbf{0 , 0 2 7}$ & 0,070 & 0,274 & 0,503 & $\mathbf{0 , 0 5 5}$ & 0,723 \\
\hline p53 & $\mathbf{0 , 1 9 6}$ & NP & $-0,073$ & $\mathbf{0 , 1 8 1}$ & 0,019 & 0,037 & $\mathbf{0 , 2 2 8}$ \\
& $\mathbf{0 , 0 2 7}$ & & 0,414 & $\mathbf{0 , 0 4 3}$ & 0,829 & 0,725 & $\mathbf{0 , 0 3 1}$ \\
\hline CD44 & $-0,162$ & $-0,073$ & NP & $-0,141$ & 0,037 & $-0,144$ & 0,038 \\
& 0,070 & 0,414 & & 0,090 & 0,659 & 0,128 & 0,694 \\
\hline PDGFRA & 0,098 & $\mathbf{0 , 1 8 1}$ & $-0,141$ & NP & $-0,152$ & $-0,056$ & 0,132 \\
& 0,274 & $\mathbf{0 , 0 4 3}$ & 0,090 & & 0,067 & 0,555 & 0,176 \\
\hline p21 & $-0,060$ & 0,019 & 0,037 & $-0,152$ & NP & 0,119 & $-0,054$ \\
& 0,503 & 0,829 & 0,659 & 0,067 & & 0,211 & 0,580 \\
\hline p27 & $\mathbf{- 0 , 1 9 9}$ & 0,037 & $-0,144$ & $-0,056$ & 0,119 & NP & $-0,121$ \\
& $\mathbf{0 , 0 5 5}$ & 0,725 & 0,128 & 0,555 & 0,211 & & 0,214 \\
\hline MVB & $-0,038$ & $\mathbf{- 0 , 2 2 8}$ & 0,038 & 0,132 & $-0,054$ & $-0,121$ & NP \\
& 0,723 & $\mathbf{0 , 0 3 1}$ & 0,694 & 0,176 & 0,580 & 0,214 & \\
\hline IDH1 & $-0,656$ & $\mathbf{- 3 , 5 5 5}$ & $-1,201$ & $-0,449$ & $-1,545$ & $-1,632$ & $-1,281$ \\
R132H & 0,512 & $\mathbf{0 , 0 0 0 1}$ & 0,230 & 0,654 & 0,122 & 0,103 & 0,200 \\
\hline
\end{tabular}

* $\mathrm{z}, \mathrm{r}_{\mathrm{s}}$ un p vērtības ir parādītas tabulā. **sā̄sinājumi tabulā: NP, nav pielietojams; MVB, mikrovaskularizācijas blīvums; PDGFRA, trombocītu atbrīvotā augšanas faktora receptors alfa; IDH1, izocitrātdehidrogenāze 1 . 


\subsubsection{DA raksturojums}

PDGFRA proteīna ekspresija uzrādīja vidēji stipru, pozitīvu korelāciju ar p53 $\left(\mathrm{r}_{\mathrm{s}}=0,544 ; \mathrm{p}=0,013\right)$. Turpretim vidēji stipra, negatīva korelācija bija starp PDGFRA un CD44 $\left(\mathrm{r}_{\mathrm{s}}=-0,592 ; \mathrm{p}=0,006\right)$.

Stipra, negatīva korelācija tika konstatēta starp PDGFRA un p21 ekspresiju $\left(\mathrm{r}_{\mathrm{s}}=-0,603 ; \mathrm{p}=0,008\right)$. Vidēji stipra, negatīva korelācija konstatēta arī starp PDGFRA un MVB ( $\left.\mathrm{r}_{\mathrm{s}}=-0,501 ; \mathrm{p}=0,034\right)$. p21 arī uzrādīja vidēji stipru, pozitīvu korelāciju ar MVB $\left(\mathrm{r}_{\mathrm{s}}=0,458 ; \mathrm{p}=0,049\right)$. Izvērsts asociāciju un korelāciju spektrs starp analizētajiem imūnhistoḳīmisko marḳieriem DA ir apkopots 2.3. tabulā.

CD44, PDGFRA ekspresija un MVB imūnhistoḳīmiska vizualizācija DA parādīta 2.10., 2.11. un 2.12 attēlā.

2.3. tabula

Savstarpējās korelācijas un asociācijas starp imūnhistoḳīmiskajiem marḳieriem DA, izmantojot Spīrmana korelācijas analīzi un Manna-Vitnija U testu

\begin{tabular}{|l|l|l|l|l|l|l|l|}
\hline Parametrs & Ki-67 & $\mathbf{p 5 3}$ & CD44 & PDGFRA & p21 & p27 & MVD \\
\hline Ki-67 & NP & 0,339 & $-0,130$ & $-0,002$ & 0,146 & 0,276 & 0,215 \\
& & 0,106 & 0,544 & 0,992 & 0,551 & 0,226 & 0,350 \\
\hline p53 & 0,339 & NP & $-0,382$ & $\mathbf{0 , 5 4 4}$ & $-0,260$ & 0,149 & 0,274 \\
& 0,106 & & 0,066 & $\mathbf{0 , 0 1 3}$ & 0,282 & 0,518 & 0,230 \\
\hline CD44 & $-0,130$ & $-0,382$ & NP & $\mathbf{- 0 , 5 9 2}$ & 0,170 & 0,302 & $\mathbf{0 , 4 9 0}$ \\
& 0,544 & 0,066 & & $\mathbf{0 , 0 0 6}$ & 0,474 & 0,162 & $\mathbf{0 , 0 1 8}$ \\
\hline PDGFRA & $-0,002$ & $\mathbf{0 , 5 4 4}$ & $\mathbf{- 0 , 5 9 2}$ & NP & $\mathbf{- 0 , 6 0 3}$ & 0,149 & $\mathbf{- 0 , 5 0 1}$ \\
& 0,992 & $\mathbf{0 , 0 1 3}$ & $\mathbf{0 , 0 0 6}$ & & $\mathbf{0 , 0 0 8}$ & 0,555 & $\mathbf{0 , 0 3 4}$ \\
\hline p21 & 0,146 & $-0,260$ & 0,170 & $\mathbf{- 0 , 6 0 3}$ & NP & $-0,290$ & $\mathbf{0 , 4 5 8}$ \\
& 0,551 & 0,282 & 0,474 & $\mathbf{0 , 0 0 8}$ & & 0,229 & $\mathbf{0 , 0 4 9}$ \\
\hline p27 & 0,276 & 0,149 & 0,302 & 0,149 & $-0,290$ & NP & 0,204 \\
& 0,226 & 0,518 & 0,162 & 0,555 & 0,229 & & 0,350 \\
\hline MVD & 0,215 & $-0,274$ & $\mathbf{0 , 4 9 0}$ & $\mathbf{- 0 , 5 0 1}$ & $\mathbf{0 , 4 5 8}$ & 0,204 & NP \\
& 0.350 & 0.230 & $\mathbf{0 , 0 1 8}$ & $\mathbf{0 , 0 3 4}$ & $\mathbf{0 , 0 4 9}$ & 0,350 & \\
\hline IDH1 R132H & 0,973 & $-0,234$ & $-0,794$ & $-0,568$ & 1,284 & $-1,589$ & $-0,122$ \\
& 0,343 & 0,815 & 0,457 & 0,612 & 0,230 & 0,112 & 0,907 \\
\hline
\end{tabular}

* z, $\mathrm{r}_{\mathrm{s}}$ un p vērtības ir parādītas tabulā. ** saīsinājumi tabulā: NP, nav pielietojams; MVB, mikrovaskularizācijas blīvums; PDGFRA, trombocītu atbrīvotā augšanas faktora receptors alfa; IDH1, izocitrātdehidrogenāze 1. 

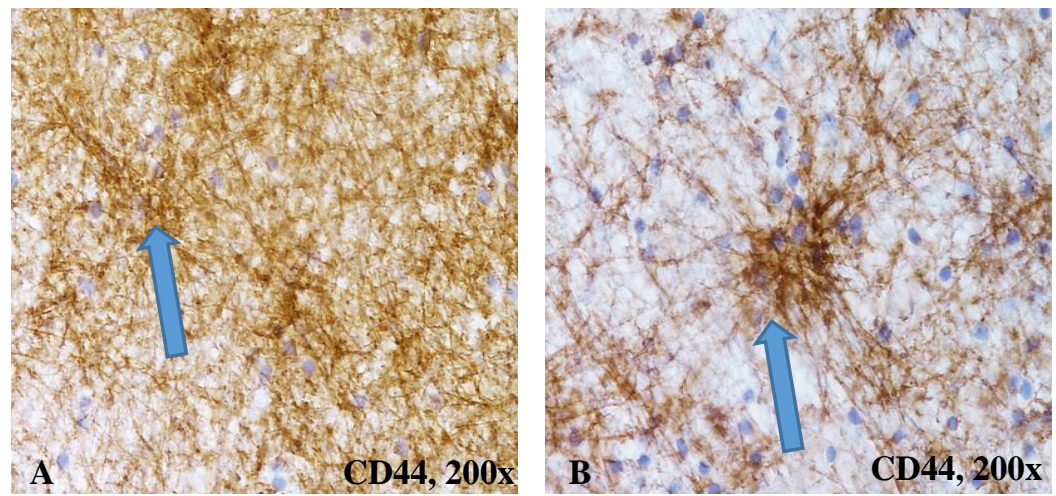

2.10. attēls. CD44 ekspresija DA. Redzama vāja, maz izteikta CD44 ekspresija astrocìtu fibrilārajos citoplazmiskajos izaugumos, kā arī augstākas ekspresijas intensitātes apvidus (bultiṇa), anti-CD44 Attēla palielinājums $200 \times$.

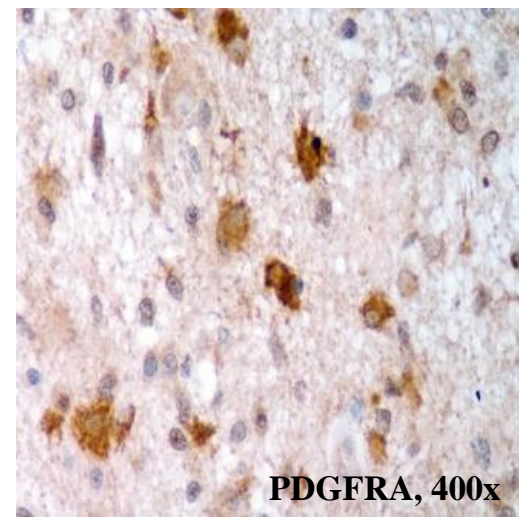

2.11. attēls. Citoplazmiska PDGFRA ekspresija DA, anti-PDGFRA

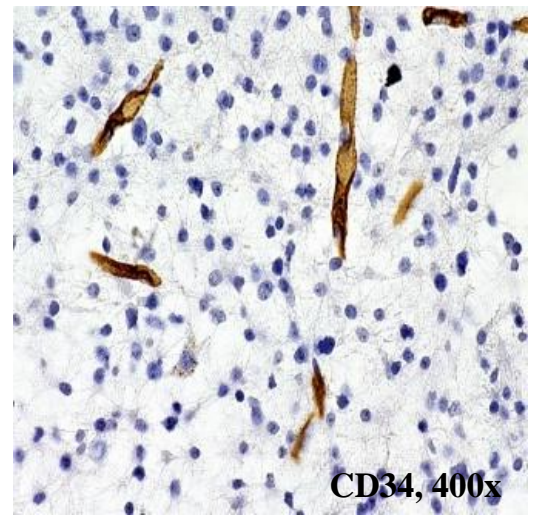

2.12. attēls. Mikroasinsvadi DA, anti-CD34

Attēla palielinājums 400×.

Attēla palielinājums 400×. 


\subsection{Izdzīvotība}

\subsubsection{GBM raksturojums}

Izdzīvotības funkcijas analīze tika veikta 135 pacientiem. Starp izsekotajiem pacientiem 133/135 (98,5\%; $95 \%$ TI $=94,8-99,6)$ nomira pētījuma laikā, bet 2/135 $(1,5 \%$; $95 \%$ TI $=0-5,2)$ pacienti bija dzīvi. Mediānais izdzīvotības laiks bija 7,9 (95 \% TI = 6,8-9,0) mēneši. Atbilstoša KaplānaMeijera līkne redzama 2.13 attēlā.

Pirmā mēneša laikā pēc operācijas nomira 6/135 (4,5 \%; 95 \% TI = 2,09,3), bet 129/135 (95,5\%; $95 \%$ TI $=90,6-97,9)$ pacienti izdzivoja. Sešus mēnešus pēc operācijas nomira 53/135 (39,3\%; $95 \% \mathrm{TI}=31,4-47,7)$ pacienti. Gadu pēc operācijas nomira 86/135 (63,7\%; 95\% TI $=55,3-71,3)$ pacienti. Divus gadus pēc operācijas nomira 122/135 (90,4\%; $95 \%$ TI = 84,2-94,3) pacienti. Trīs gadus pēc operācijas nomira 133/135 (98,5\%; $95 \%$ TI = 94,899,6) pacienti.

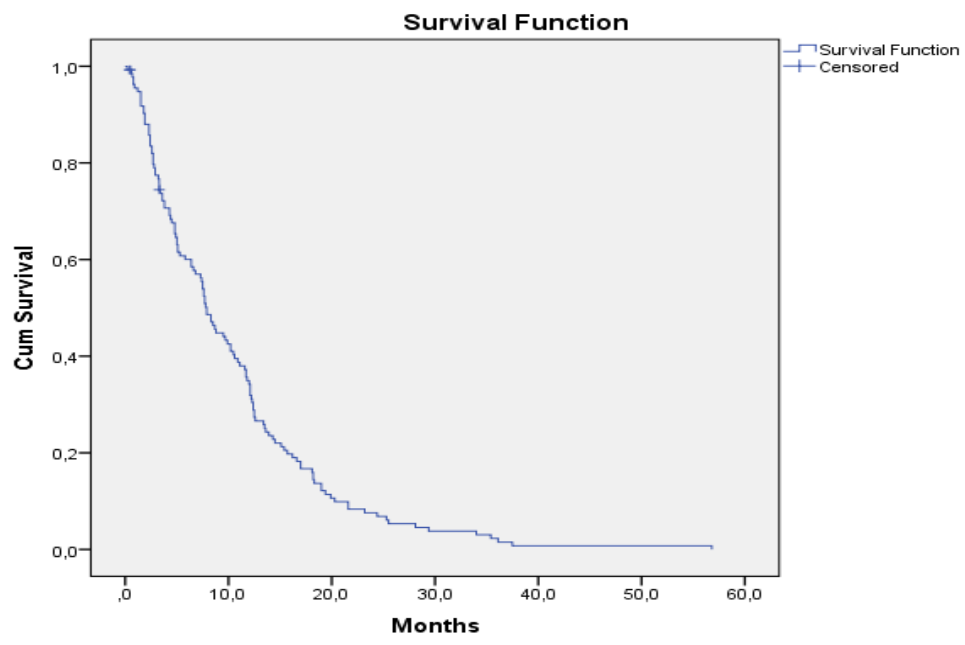

2.13. attēls. Kaplāna-Meijera kumulatīvās izdzivotības līkne pacientiem ar GBM 


\subsubsection{DA raksturojums}

Izdzīvotības funkcijas analīze tika veikta 25 pacientiem. Starp izsekotajiem pacientiem 11/25 (44,0\%; $95 \% \mathrm{TI}=26,6-62,9)$ nomira pètījuma laikā, bet 14/25 (56,0\%; $95 \%$ TI = 37,0-73,3) pacienti bija dzīvi. Sakarā ar mazu pētījuma un mirušu pacientu grupu statistiski aprēķini ir apgrūtinoši, kā arī mediāno izdzīvotības laiku aprēķināt nav iespējams. Atbilstoša Kaplāna-Meijera līkne redzama 2.14 attēlā. Kā redzams līknē, pacientu izdzīvotības rādītāji nenokritās zem 0,5 .

Gadu pēc operācijas nenomira neviens no izdzīvotības analīzē iekḷautajiem pacientiem. Divus gadus pēc operācijas nomira 3/25 (12 \%; $95 \%$ $\mathrm{TI}=4,2-29,9)$ pacienti. Trīs gadus pēc operācijas nomira 5/25 (20\%; $95 \%$ $\mathrm{TI}=8,8-39,1)$ pacienti.

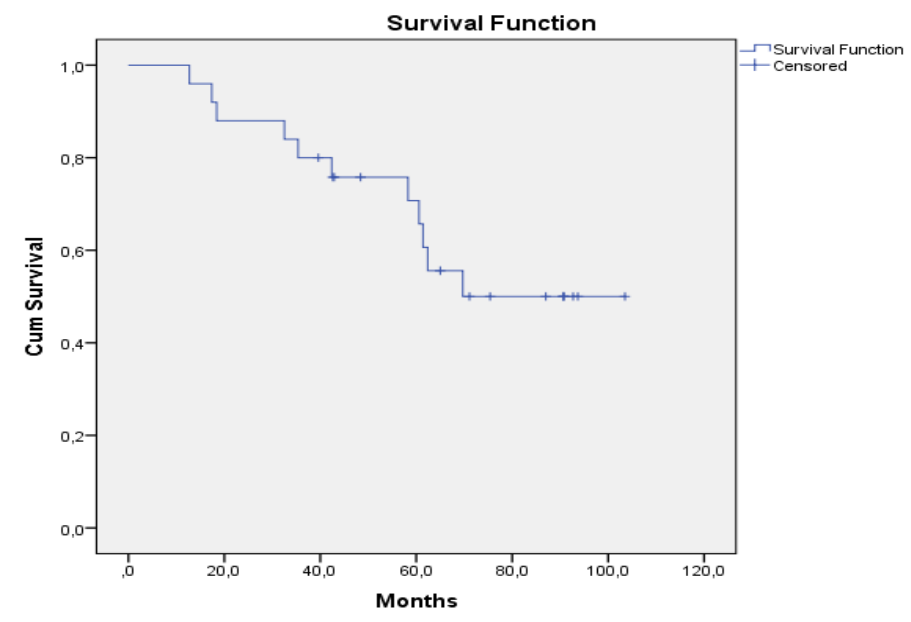

2.14. attēls. Kaplāna-Meijera kumulatīvās izdzivotības līkne pacientiem ar DA 


\subsection{Asociācijas starp izdzīvotības laiku un klīniskajiem parametriem}

\subsubsection{GBM raksturojums}

Izdzīvotības laika analīzes rezultāti atklāja statistiski nozīmīgu atšķirību attiecībā uz pacientu vecumu (log-rank, p < 0,001). Mediānais izdzīvotības laiks pacientiem, kuri bija jaunāki par 65 gadiem bija 11,7 (95\% TI = 8,1-15,3) mēneši, turpretim tikai 5 (95\% TI = 3,2-6,8) mēneši pacientiem, kuri bija vecāki par 65 gadiem. Tādējādi gados jaunāki GBM pacienti zem 65 gadiem bija ar ilgākiem izdzīvotības rādītājiem (2.15. attēls).

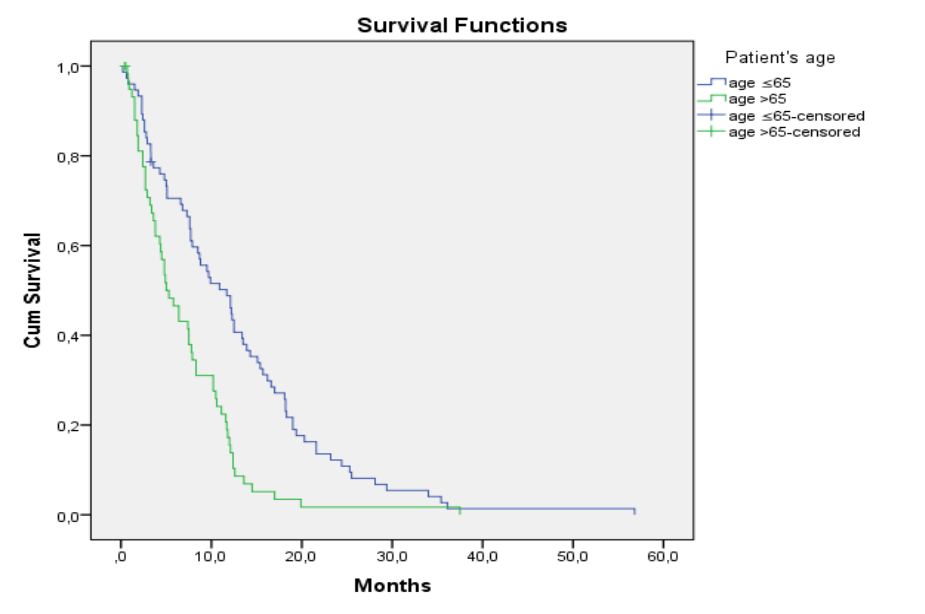

\subsection{5. attēls. Kaplāna-Meijera kumulatīvās izdzīvotības līkne attiecībā uz GBM pacientu vecumu}

Statistiski nozīmīga mediānās izdzīvotības laika atšķirība tika konstatēta attiecībā uz audzēja lokalizāciju (log-rank, p = 0,018). Tendence uz augstākiem GBM pacientu izdzīvotības rādītājiem konstatēta paura daivās lokalizētiem audzējiem, salīdzinot ar lokalizāciju pieres daivā (log-rank, p =0,06). Lieli audzēji, kuri infiltrēja vairākas daivas, bija ar vissliktāko prognozi. Mediānais 
izdzīvotības laiks pacientiem ar GBM lokalizāciju pieres, deniņu un paura daivās bija atbilstoši 8,3 (95 \% TI = 6,7-9,8) mēneši, 7,7 (95 \% TI = 4,0-11,4) mēneši, 12,6 (95 \% TI = 10,4-14,8) mēneši. Salīdzinājumā, pacientiem ar audzējiem, kuri infiltrēja vairākas daivas mediānais izdzīvotības laiks bija 6,4 (95\% TI = 3,7-9,0) mēneši. Atbilstoša Kaplāna-Meijera līkne redzama 2.16 attēlā.

Analizējot izdzīvotības rādītājus attiecībā uz audzēja lokalizāciju, ņemot vērā pacientu vecumu, konstatēja, ka statistiski ticamas izdzīvotības rādītāju atšķirības ir tikai gados jaunākiem pacientiem (< 65 gadiem). Tādējādi pacientiem, kuri ir jaunāki par 65 gadiem, konstatēja statistiski ticamu atšķirību starp izdz̄ivotības rādītājiem paura un pieres daivās lokalizētiem audzējiem $(\mathrm{p}=0,018)$.

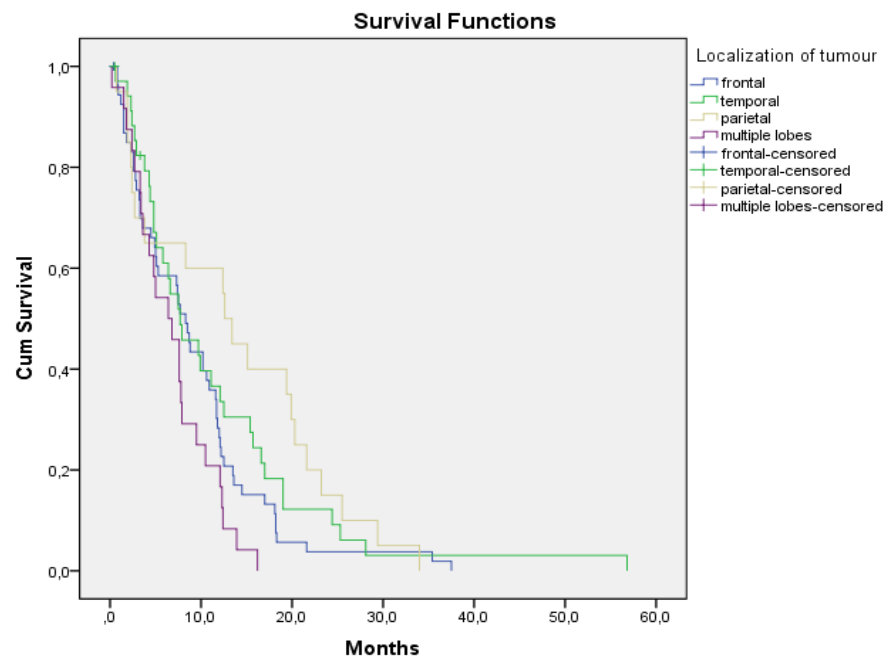

2.16. attēls. Kaplāna-Meijera kumulatīvās izdzīvotības līkne attiecībā uz GBM lokalizāciju

Statistiski nozīmīga mediānās izdzīvotības laika atškirīiba tika konstatēta arī attiecībā uz audzēja izmēru (log-rank, p = 0,018). Mediānais izdzīvotības laiks pacientiem ar audzējiem ar izmēru zem $4 \mathrm{~cm}$ bija 11,8 (95\% TI = 8,1-15,5) 
mēneši, salīdzinot ar 6,8 (95 \% TI = 4,7-8,8) mēnešiem audzējiem ar izmēru virs 4 cm. Atbilstoša Kaplāna-Meijera līkne redzama 2.17. attēlā.

Pacientiem ar multifokālām GBM izdzīvotības rādītāji bija daudz zemāki, salīdzinot ar solitāriem audzējiem (log-rank, p =0,002). Mediānais izdzīvotības laiks pacientiem ar multifokālām GBM bija 3,4 (95\% TI = 0-6,9) mēneši, savukārt solitāriem audzējiem tas bija 8,7 (95\% TI = 6,8-10,6) mēneši. Atbilstoša Kaplāna-Meijera līkne redzama 2.18. attēlā.

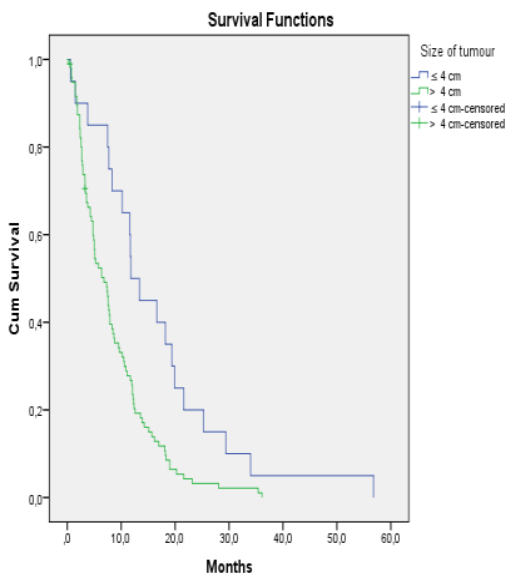

2.17. attēls. Kaplāna-Meijera kumulatīvās izdzīvotības līkne pacientiem attiecībā uz GBM izmēru

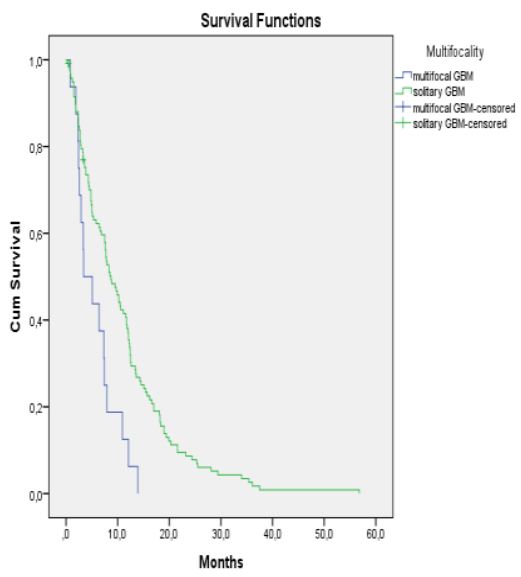

2.18. attēls. Kaplāna-Meijera kumulatīvās izdzīvotības līkne pacientiem attiecībā uz GBM multifokalitāti

Statistiski nozīmīga mediānās izdzīvotības laika atšķirība tika konstatēta attiecībā uz saņemto ārstēšanas veidu GBM pacientiem $(\log$-rank, $\mathrm{p}<0,001)$. Tādējādi mediānās izdzînotības laiks pacientiem, kuri saṇēmuši maksimāli iespējamo standartterapiju, t. i., ķirurǵisku ārstēšanu, kurai sekoja adjuvanta ķīmijterapija ar temozolamīdu un radioterapija, bija 12,1 (95 \% TI = 11,2-13,0) mēneši. Savukārt pacientiem, kuriem ķirurğiska ārstēšana bija papildināta tikai ar radioterapiju vai, kuriem veikta tikai audzēja ķirurǵiska rezekcija bez 
adjuvantas terapijas, bija atbilstoši 7,5 (95 \% TI - 5,4-9,6) mēneši un 2,9 (95 \% TI = 1,4-4,4) mēneši. Atbilstoša Kaplāna-Meijera līkne redzama 2.19. attēlā.

Izdzīvotības laika analīzē netika konstatētas statistiski ticamas izdzīvotības atšḳirības starp dzimumiem $(\mathrm{p}=0,560)$.

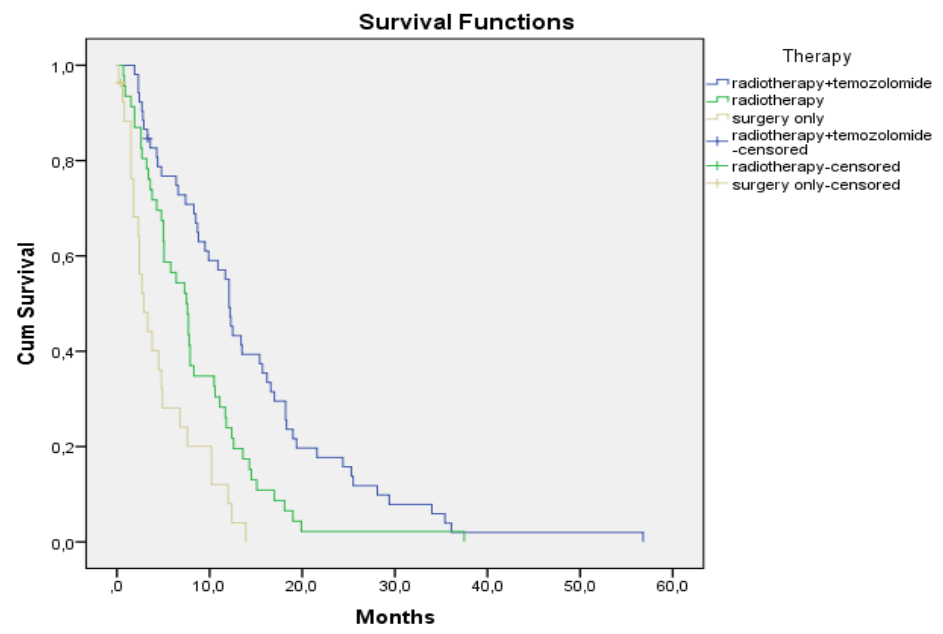

\subsection{9. attēls. Kaplāna-Meijera kumulatīvās izdz̄ivotības līkne GBM pacientiem attiecībā uz terapijas veidu}

\subsubsection{DA raksturojums}

Statistiski nozīmīga mediānās izdzīvotības laika atšksirība tika konstatēta dažādu dzimumu pacientiem (log-rank, p = 0,002). Tādējādi sievietēm bija augstāki izdzīvotības laika rādītāji, salīdzinot ar vīriešiem (2.20. attēls). Pētījuma beigās izdzīvoja 11/13 (84,6 \%; $95 \% \mathrm{TI}=57,8 \%-95,7 \%)$ sieviešu un tikai 3/12 (25 \%; 95 \% TI = 8,9-57,2 \%) vīriešu. Mediānais izdzīvotības laiks vīriešiem ar DA diagnozi bija 58,3 (95 \% TI = 31,1-85,0) mēneši. Mediāno izdzīvotības laiku sievietēm nevar aprēḳināt, ņemot vērā mazu pētījuma grupu, t. i., tikai divi nāves gadījumi. 


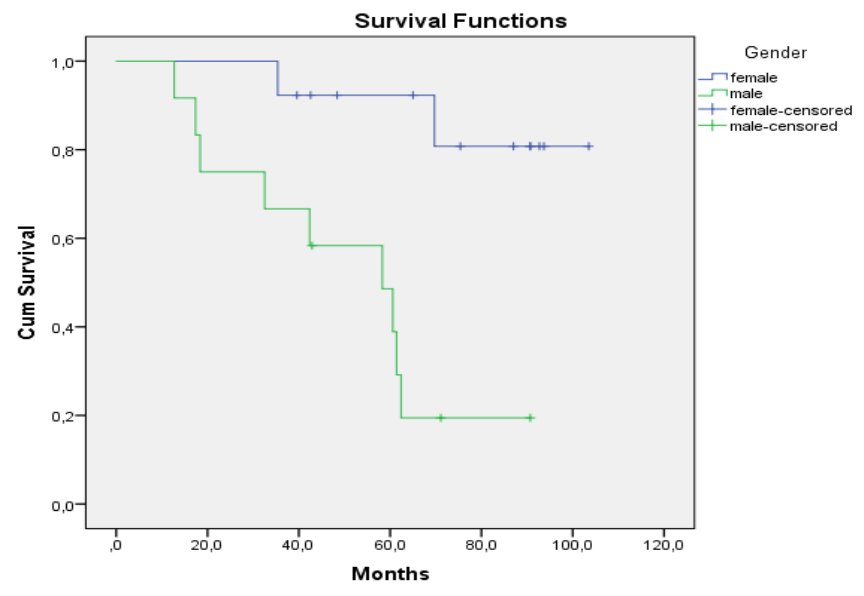

\subsection{0. attēls. Kaplāna-Meijera kumulatīvās izdzìvotības līkne DA pacientiem pēc dzimuma}

Statistiski ticamas izdzīvotības laika atšķirības attiecībā uz audzēja lokalizāciju netika konstatētas ( $\mathrm{p}=0,812)$. Visas DA bija lieli audzēji virs $4 \mathrm{~cm}$ diametrā, tādēḷ audzēja izmēru grupas netika iekḷautas izdzīvotības laika analīzē.

\subsection{Asociācijas starp izdzīvotības laiku un imūnhistoḳīmiskajiem parametriem}

\subsubsection{GBM imūnhistoḳīmiskie prognostiskie marḳieri}

Statistiski ticamas GBM pacientu izdzīvotības laika rādītāju atškirīības konstatētas tikai attiecībā uz IDH1 R132H mutācijas produkta ekspresijas noteikšanu (log-rank, p = 0,040). Tādējādi mediānais izdzīvotības laiks pacientiem ar sekundāru GBM (IDH1 R132H pozitīva) bija 18,3 (95 \% TI = 18,0-18,5) mēneši, savukārt pacientiem ar primāru GBM (IDH1 R132H negatīva) tas bija krietni īsāks - 7,7 (95\% TI = 6,3-9,0) mēneši. Atbilstoša Kaplāna-Meijera līkne redzama 2.21. attēlā. 


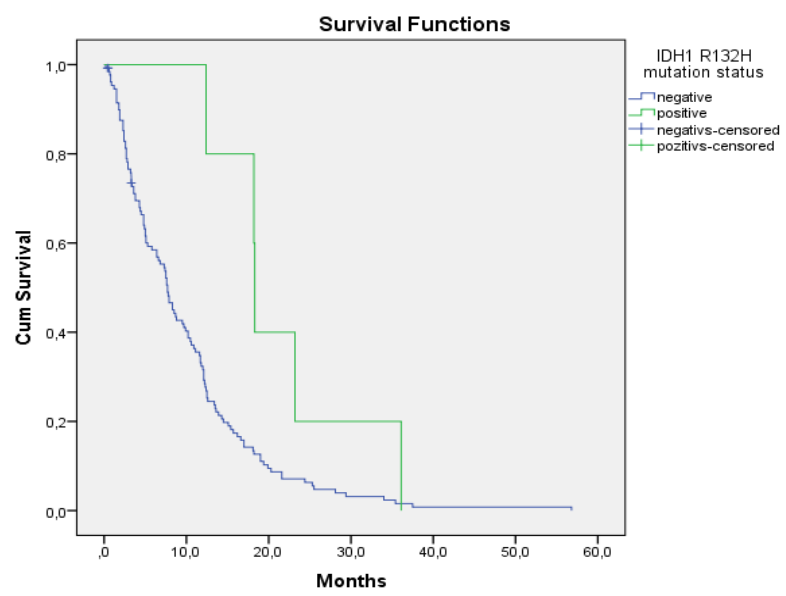

2.21. attēls. Kaplāna-Meijera kumulatīvās izdzivotības līkne GBM pacientiem attiecībā uz IDH1 R132H

Attiecībā uz PDGFRA ekspresiju, izmantojot ekspresijas robežvērtību $50 \%$, izdzīvotības laika rādītāju analīzē konstatēta tikai norāde uz tendenci par iespējamu rādītāju atšķirību, taču rezultāts nav statistiski ticams (log-rank, p = 0,066). Apskatot Kaplāna-Meijera kumulatīvās izdzivvotības līknes, var konstatēt vizuālu atšķirību starp līkni ar augstu un zemu PDGFRA ekspresiju. Taču pētījumā bija maz pacientu ar augstu PDGFRA ekspresiju, lai precizētu PDGFRA ietekmi uz izdzīvotības laiku. GBM pacientiem ir vēlama lielāka pacientu grupa ar augstu PDGFRA ekspresiju. Mediānais izdzīvotības laiks pacientiem ar augstu PDGFRA ekspresiju bija 6,4 (95 \% TI = 2,8-9,9) mēneši, bet ar zemu ekspresiju - 8,3 (95 \% TI = 6,4-10,1) mēneši. Atbilstoša KaplānaMeijera līkne redzama 2.22. attēlā.

Attiecībā uz Ki-67 proliferācijas frakciju statistiski ticama izdzìvotības laika atšķirība netika konstatēta (log-rank, p = 0,252). Toties, izmantojot ekspresijas robežvērtību $25 \%$, vizuāli ir redzamas augstas un zemas Ki-67 ekspresijas izdzīvotības laika līkṇu nelielas atškirīibas. Tādējādi līknes pārklājas 
pirmajos 5 mēnešos, vēlāk attālinās viena no otras un krustojas atkal tikai pēc 20 mēnešu izsekošanas laika. Mediānais izdzīvotības laiks pacientiem ar augstu Ki-67 proliferāciju bija 7,4 (95 \% TI = 5,7-9,1) mēneši, savukārt ar zemu proliferāciju - 13,5 (95\% TI = 9,1-17,8) mēneši. Atbilstoša Kaplāna-Meijera līkne redzama 2.23. attēlā.

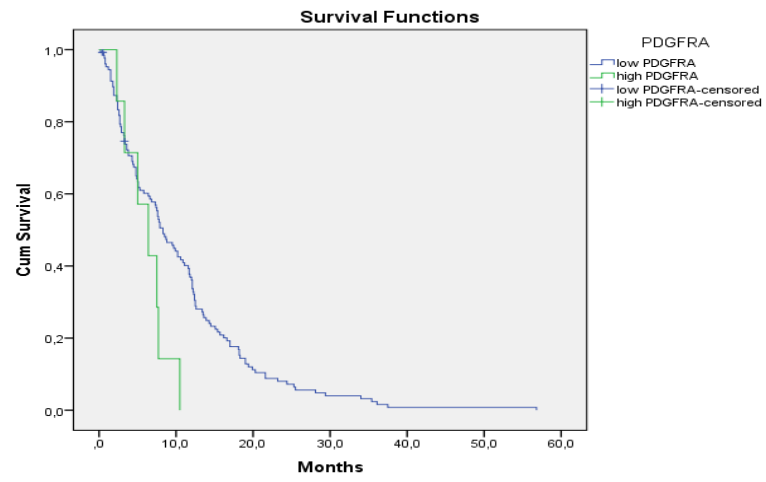

2.22. attēls. Kaplāna-Meijera kumulatīvās izdzīvotības līkne GBM pacientiem attiecībā PDGFRA (robežvērtība 50 \%)

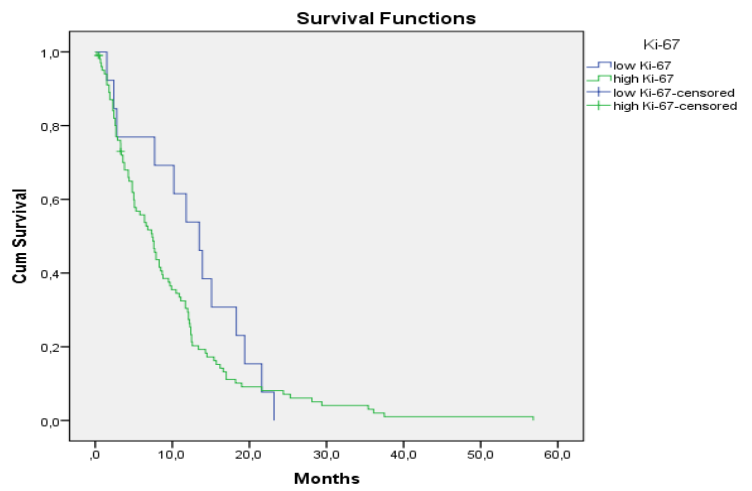

2.23. attēls. Kaplāna-Meijera kumulatīvās izdzīvotības līkne GBM pacientiem attiecībā Ki-67 (robežvērtība $25 \%$ ) 


\subsubsection{DA imūnhistoḳīmiskie prognostiskie marḳieri}

Statistiski ticama izdzīvotības laika atšḳirība tika konstatēta pacientiem ar DA attiecībā uz Ki-67 proliferācijas frakciju, izmantojot ekspresijas robežvērtību $5,5 \%$ (log-rank, $\mathrm{p}=0,037$ ). Augsta Ki-67 proliferācijas frakcija (virs 5,5\%) konstatēta 12/23 (52,2\%; $95 \%$ TI = 33,0-70,8) pacientiem, savukārt zema proliferācija bija 11/23 $(47,8 \%$; $95 \% \mathrm{TI}=29,2-67,0)$ pacientiem. Pētījuma beigās, audzēju grupā ar augstu proliferāciju nomira 7/12 (58,3 \%; 95 \% TI = 31,9-80,7) pacientu, salīdzinot ar 2/11 (18,2 \%; $95 \%$ TI = 5,1-47,7) pacientiem audzēju grupā ar zemu proliferāciju. Mediānais izdzīvotības laiks DA pacientiem ar augstu Ki-67 proliferāciju bija 60,6 (95 \% TI = 35,3-85,9) mēneši. Mediāno izdzīvotības laiku zemas proliferācijas audzēju grupā nevarēja aprēḳināt sakarā ar zemo nāves gadījumu skaitu. Atbilstoša Kaplāna-Meijera līkne redzama 2.24. attēlā.

Statistiski ticama izdzīvotības laika atškirīiba tika konstatēta pacientiem ar DA attiecībā uz PDGFRA ekspresiju, izmantojot ekspresijas robežvērtību $50 \%$ (log-rank, p = 0,017). Augsta PDGFRA ekspresija (virs $50 \%$ ) konstatēta 10/19 $(52,6 \% ; 95 \%$ TI = 31,7-72,6) pacientiem, savukārt zema ekspresija bija 9/19 $(47,3 \%$; $95 \%$ TI = 27,3-68,3) pacientiem. Pētījuma beigās audzēju grupā ar augstu PDGFRA ekspresiju nomira 1/10 (10\%; $95 \%$ TI = 1,8-40,4) pacientu, salīdzinot ar 5/9 (55,6\%; $95 \%$ TI = 26,7-81,1) pacientiem audzēju grupā ar zemu PDGFRA ekspresiju. Mediānais izdzīvotības laiks DA pacientiem ar zemu PDGFRA ekspresiju bija 61,4 (95\% TI = 9,9-112,0) mēneši. Mediāno izdzīvotības laiku augstas PDGFRA ekspresijas audzēju grupā nevarēja aprēķināt sakarā ar zemo nāves gadījumu skaitu pētāmā grupā. Atbilstoša Kaplāna-Meijera līkne redzama 2.25. attēlā.

Attiecībā uz pārējiem pētītajiem imūnhistoḳīmiskajiem marḳieriem statistiski nozīmīgas atšķirības, analizējot izdzīvotības laiku, nekonstatēja. 


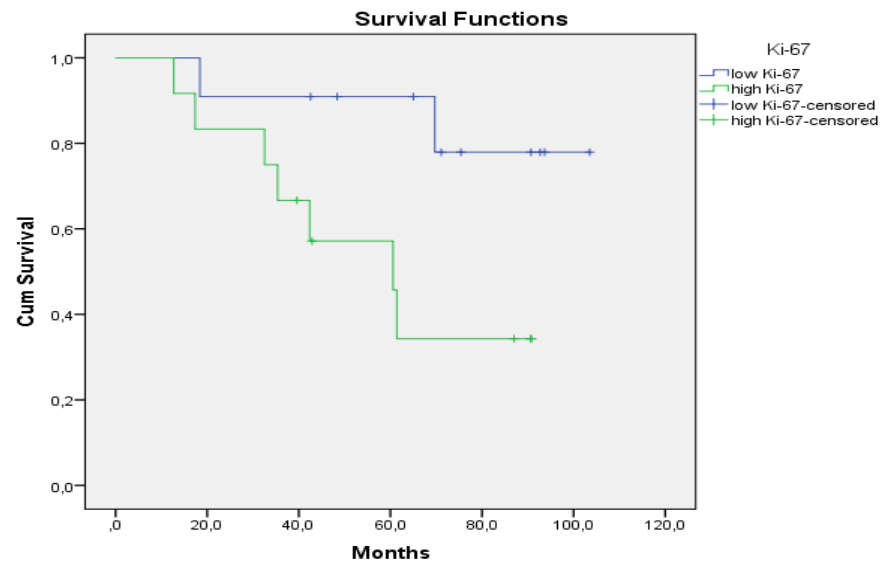

2.24. attēls. Kaplāna-Meijera kumulatīvās izdzìvotības līkne DA pacientiem attiecībā Ki-67 (robežvērtība 5,5\%)

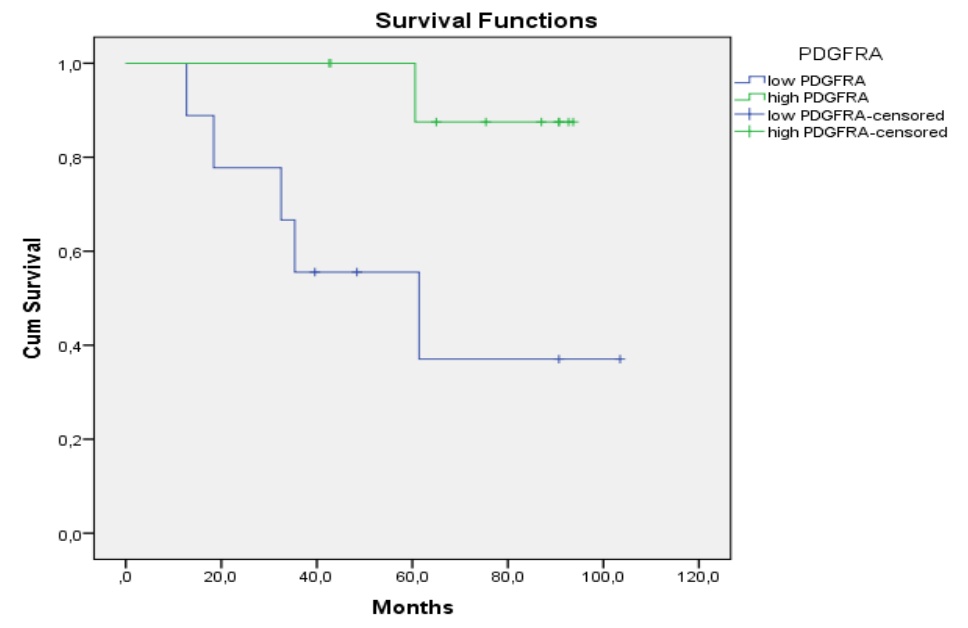

2.25. attēls. Kaplāna-Meijera kumulatīvās izdzīvotības līkne DA pacientiem attiecībā PDGFRA (robežvērtība $50 \%$ ) 


\subsection{Gliomu imūnhistoḳīmiskie subtipi un izdzīvotības laiks}

Gliomu subtipu noteikšana veikta, analizējot šādu imūnhistokīimisku marķieru ekspresiju - p53, IDH1 R132H, PDGFRA un CD44 (skat. Materiāli un metodes). Balstoties uz šo marķieru ekspresijas signatūrām, tika izškirtas trīs GBM kategorijas: proneirāls, mezenhimāls un neklasificēts subtips, apzīmēts ar "Cits". Gliomu subtipu noteikšana tika pārbaudīta ar divām dažādas imūnhistoḳīmisko marķieru ekspresijas robežvērtībām, kuras tika izvēlētas gan pēc starptautiskajos pētījumos aprakstītajām robežvērtībām līdzīga rakstura pētījumos, gan balstoties uz mediāno marķiera ekspresijas vērtību šajā pētījumā.

\subsubsection{GBM imūnhistoķīmiskie subtipi}

Lielākā daḷa no GBM gadījumiem piederēja pie proneirālā subtipa 73/146 (50,0\%; $95 \%$ TI $=42,0-58,0)$, tam neklasificēta subtipa gadījumi $46 / 146(31,5 \%$; $95 \% \mathrm{TI}=24,5-39,4)$ un mezenhimāla subtipa gadījumi 27/146 (18,5\%; 95 \% TI = 13,0-25,6). Pētījumā netika konstatētas asociācijas starp GBM subtipiem un pārējo analizēto imūnhistoḳīmisko marķieru ekspresiju (Ki-67, MVD, p21, p27). Izdzīvotības laika analīzes rezultāti neatklāja statistiski nozīmīgas atšķirības starp GBM subtipiem (log-rank, p = 0,424) (2.26.A attēls). Taču, kad tika analizēta pielietotās terapijas efektivitāte attiecībā uz katru subtipu, tika konstatētas statistiski ticamas mediānās izdzīvotības laika atšķirības starp GBM subtipiem. Atbilstoša Kaplāna-Meijera līkne apskatāmas 2.26. attēlā.

Proneirāla subtipa gadījumā tika novērota tendence mediānajam izdzīvotības laikam atšķirties (log-rank, p = 0,061) starp pacientiem, kuri saņēmuši standarta terapiju ar temozolamīdu un radioterapiju, salīdzinot ar pacientiem, kuri ir saņēmuši tikai radioterapiju. Veicot Kaplāna-Meijera kumulatīvās izdzīvotības līknes analīzi, iezīmējas arī izteikta vizuāla tendence uz atšķirīgiem līknes kritumiem (2.26.B attēls). Saņemot tikai radioterapiju, mediānais izdzīvotības laiks pacientiem ar proneirālu GBM subtipu ir statistiski 
ticami lielāks (log-rank; $\mathrm{p}=0,008)$, salīdzinot ar pacientiem, kuriem veikta tikai ķirurǵiska audzēja rezekcija bez adjuvantas terapijas.

Mezenhimāla subtipa gadījumā pacientiem, kuri saṇēmuši standarta adjuvantu terapiju ar temozolamīdu, novēroja statistiski ticami labākus (log-rank; $\mathrm{p}=0,002$ ) mediānās izdzīvotības rādītājus, salīdzinot ar pacientiem, kuri saņēmuši tikai radioterapiju. Savukārt, atšķirīibā no proneirālā subtipa, pacientiem ar GBM mezenhimālo subtipu adjuvanta radioterapija nav uzlabojusi izdzīvotības laiku, salīdzinot ar tikai ķirurǵisku ārstēšanu saṇēmušajiem pacientiem (log-rank; p = 0,857) (2.26.C attēls). Tādējādi rezultāti parāda, ka adjuvantai radioterapijai nav labvēlīga terapeitiskā efekta un tā neietekmē pacientu izdzīvotības laiku, mezenhimālā GBM subtipa gadījumā.

Pārējiem GBM gadījumiem, kurus neizdevās iekḷaut atbilstoša subtipa kategorijā, netika konstatētas statistiski ticamas atškirīības starp izdzīvotības rādītājiem šādās grupās: adjuvanta ķīmijterapija ar temozolamīdu kopā ar radioterapiju, salīdzinot ar tikai adjuvantu radioterapiju saņēmušajiem pacientiem ( $\mathrm{p}=0,319), k a \bar{a}$ ari starp tikai adjuvantu radioterapiju saņēmušajiem un tikai ķirurgisisku ārstēšanu saņēmušajiem pacientiem $(\log$-rank; p = 0,080) (2.26.D attēls). Atbilstošas Kaplāna-Meijera līknes apskatāmas 2.26. attēlā. Mediānās izdzìvotības laika rādītāji katram GBM subtipam atkarībā no saṇemtās ārstēšanas kopā ar p-vērtībām ir apkopoti 2.4. tabulā.

Papildus iepriekš aprakstītajiem subtipiem ir izmēǵināta subtipu noteikšana, izmantojot arī šajā pētījumā iegūtās markiieru robežvērtības, kuras balstītas uz marķiera mediāno ekspresijas daudzumu. Atbilstoši uz mediāno marķiera ekspresiju balstītām robežvērtībām, GBM subtipu sadalījums bija šāds: proneirāls subtips 95/146 (65,1 \%; 95 \% TI = 57,0-72,3), neklasificēts subtips 32/146 (21,9 \%; 95 \% TI = 15,9-29,3), mezenhimāls subtips - 19/146 (13,0\%; 95\% TI = 8,5-19,4). Arī šajā gadījumā netika konstatētas asociācijas starp GBM subtipu un citiem pētītajiem imūnhistoḳīmiskajiem marķieriem (Ki-67, MVD, 
p21, p27). Izdzīvotības laika analīzes rezultāti arī neatklāja statistiski nozīmīgas atšķirīibas starp GBM subtipiem (log-rank, p = 0,511). Analizējot šo GBM subtipu izdzīvotības laika atšksirības, atkarībā no saņemtā terapijas veida, konstatē līdzīgus rezultātus, kā arī veicot Kaplāna-Meijera kumulatīvās izdzīvotības līknes analīzi, ir līdzịga vizuāla tendence uz atšķirīgiem līknes kritumiem, kā tas bija GBM subtipiem, kuri balstîjās uz literatūrā aprakstītajām marķieru robežvērtībām.

2.4. tabula

Mediānās izdzīvotības laiki pacientiem ar dažādiem GBM subtipiem, atkarībā no saṇemtās terapijas veida, kopā ar p vērtībām

\begin{tabular}{|c|c|c|c|c|c|c|}
\hline $\begin{array}{l}\text { Subtips } \\
(\mathbf{n}=135 *)\end{array}$ & $\begin{array}{l}\text { Saṇemtā terapija } \\
\qquad\left(\mathbf{n}=135^{*}\right)\end{array}$ & $\begin{array}{l}\text { Mediānais } \\
\text { izdzīvotības } \\
\text { laiks }\end{array}$ & $95 \%$ TI & \multicolumn{3}{|c|}{ p vērtības } \\
\hline \multirow[t]{3}{*}{$\begin{array}{l}\text { Proneirāls } \\
(\mathrm{n}=66)\end{array}$} & $\begin{array}{l}\text { TMZ + radioterapija } \\
(\mathrm{n}=25)\end{array}$ & 12,3 & $\overline{8,4-16,2}$ & \multirow[t]{2}{*}{$\begin{array}{l}0 \\
8 \\
8 \\
8\end{array}$} & & \multirow{3}{*}{$\begin{array}{l}\hat{o} \\
\dot{8}\end{array}$} \\
\hline & $\begin{array}{l}\text { Radioterapija } \\
(\mathrm{n}=27)\end{array}$ & 7,6 & $7,1-8,1$ & & \multirow{2}{*}{$\stackrel{0}{8}$} & \\
\hline & $\begin{array}{l}\text { Tikai k̦irurǵija } \\
(\mathrm{n}=14)\end{array}$ & 2,4 & $1,1-3,6$ & & & \\
\hline \multirow[t]{3}{*}{$\begin{array}{l}\text { Mezenhimāls } \\
(\mathrm{n}=26)\end{array}$} & $\begin{array}{l}\text { TMZ + radioterapija } \\
(\mathrm{n}=11)\end{array}$ & 11,7 & $6,4-16,9$ & \multirow{2}{*}{ : } & & \multirow{3}{*}{$\stackrel{\circ}{8}$} \\
\hline & Radioterapija $(n=9)$ & 2,7 & $0,3-5,0$ & & \multirow{2}{*}{\begin{tabular}{l}
0 \\
$\substack{\infty \\
\hdashline \\
y}$
\end{tabular}} & \\
\hline & Tikai ķirurǵija $(n=6)$ & 2,7 & $2,0-3,3$ & & & \\
\hline \multirow[t]{3}{*}{$\begin{array}{l}\text { Cits } \\
(n=43)\end{array}$} & $\begin{array}{l}\text { TMZ + radioterapija } \\
(\mathrm{n}=20)\end{array}$ & 12,2 & $6,7-17,6$ & \multirow{2}{*}{$\stackrel{\omega}{\sigma}_{\sigma}^{0}$} & & \multirow{3}{*}{$\stackrel{\circ}{\stackrel{0}{0}}$} \\
\hline & Radioterapija $(n=14)$ & 8,3 & $3,7-12,9$ & & \multirow{2}{*}{$\begin{array}{l}0 \\
\mathscr{\infty}\end{array}$} & \\
\hline & Tikai ķirurǵija $(n=9)$ & 4,9 & $3,9-5,9$ & & & \\
\hline
\end{tabular}

* dati par saņemto terapiju bija pieejami 135 gadījumos;

** saīsinājumi tabulā: TMZ, temozolamīds; OS, TI, ticamības intervāls. 

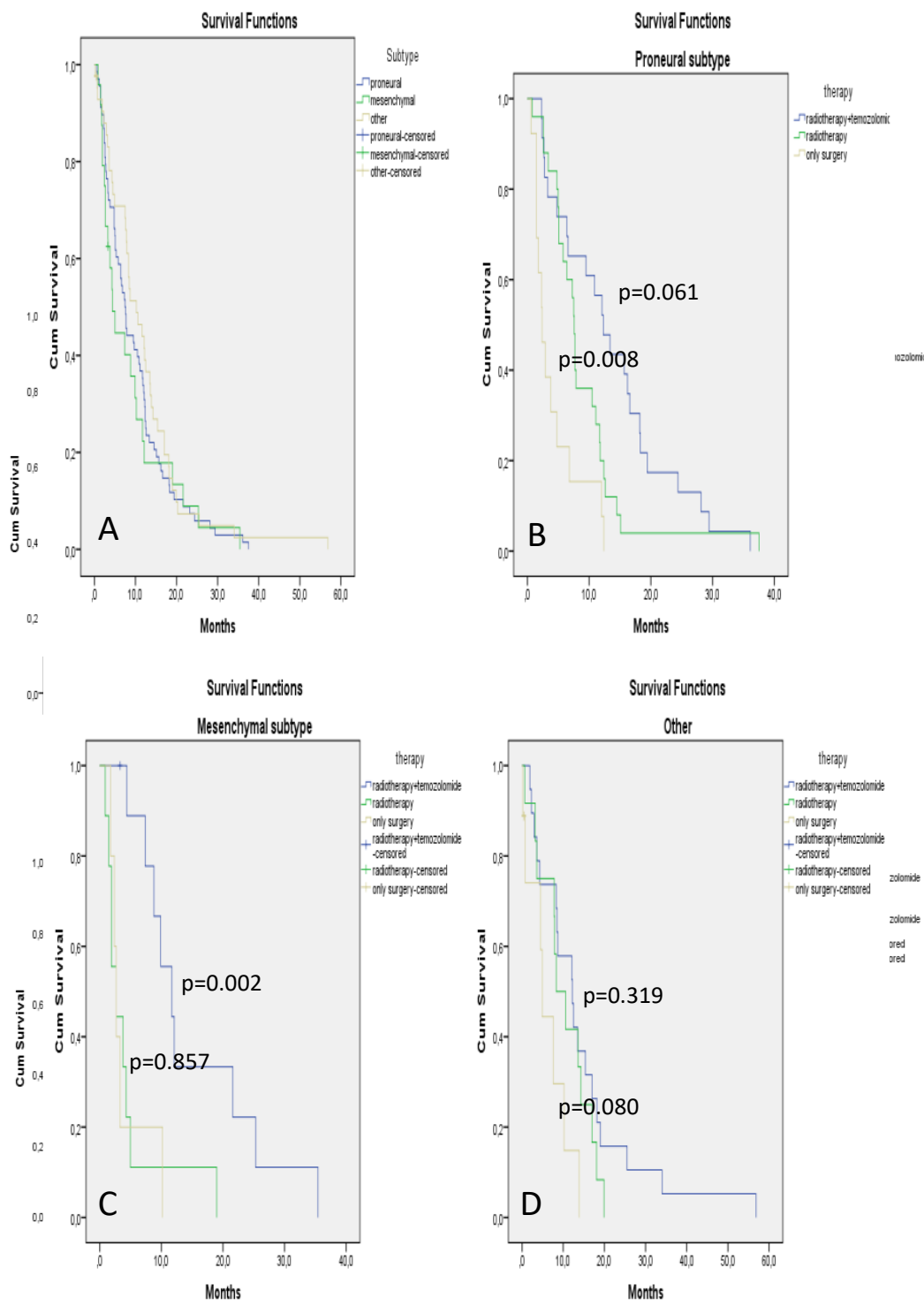

2.26. attēls. Kaplāna-Meijera kumulatīvās izdzīvotības līkne GBM pacientiem attiecībā uz GBM subtipu, ņemot vērā ārstēšanas veidu 


\subsubsection{DA imūnhistoḳ̄̄miskie subtipi}

Izmantojot abas marḳieru ekspresijas robežvērtības, lielākā daḷa no DA iekḷāvās proneirāla subtipa kategorijā - 24/26 (92,3 \%; 95\% TI = 75,8-97,9), atlikušie 2/26 (7,6 \%; 95 \% TI = 2,1-24,1\%) gadījumi piederēja pie neklasificēta subtipa. CD44 ekspresija visās DA bija ḷoti zema, izmantojot ekspresijas robežvērtību $50 \%$, tikai vienā gadījumā CD44 ekspresija sasniedza šo līmeni. Sakarā ar nelielu pētījuma grupu un proneirālas signatūras predominanci gandrīz visos DA gadījumos, izdzīvotības analīze pēc subtipa netika veikta. 


\section{Diskusija}

Difūzas gliomas incidences ziņā nav vieni no biežāk sastopamajiem l̦aundab̄̄gajiem audzējiem, bet tās noteikti ir vieni no agres̄ivākajiem audzējiem ar ḷoti ierobežotām ārstēšanas iespējām. Viena no agresīvākajām gliomām ir GBM, tādēḷ daudzi starptautiski pētījumi ir veltīi šs̄ audzēja izpētei. Ir svarīgi apzināties specifisku signālcel̦u, kā arī gliomu galveno pamatīpašību (piem., invāzija, proliferācija, rezistence pret terapiju) nosakošo specifisko molekulāru izmaiņu lomu, kas varētu sniegt cerību nākotnē uzlabot gliomu ārstēšanu un varbūt pat pavērt iespēju attīstîties personalizētai molekulārai mērḳterapijai. Mūsdienās GBM standartterapija iekḷauj maksimāli iespējamu audzēja ķirurgísku rezekciju, kuru papildina ar ķīmijterapiju ar temozolamīdu un radioterapiju, taču pat ar šādu ārstēšanu prognoze ir slikta (Stupp et al., 2014; Stupp et al., 2005). Tomēr pēdējās desmitgades laikā izpratne par gliomu molekulāro bioloǵiju ir krietni uzlabojusies, lielā mērā, pateicoties daudziem apjomīgiem pētījumiem un jauniem tehnoloǵiskiem sasniegumiem. Viens no šādiem milzīgiem sasniegumiem bija GBM šūnu pilna genoma sekvencēšana, kas veikta lielai pacientu grupai TCGA (The Cancer Genome Atlas) projekta ietvaros (Cancer Genome Atlas Research, 2008). Pateicoties šim projektam, un vēl vairākiem citiem plaša mēroga gliomu pētījumiem ir atklāti un raksturoti vairāki kritiski gliomu patoğenēzē iesaistīti gēni, piemēram, mutācijas IDH1, IDH2, EGFR, PDGFRA, ATRX u. c. gēnos ir bieži sastopamas gliālos audzējos (Brennan et al., 2013; Parsons et al., 2008; Verhaak et al., 2010; Yan et al., 2009).

Pētījumi parāda, ka GBM nav vienveidīgs audzējs, kā tika uzskatīts iepriekš, bet ir molekulāri un bioloğiski atšķirīgu audzēju grupa, pat ar identisku morfologiiju. Pētījumos konstatēti vairāki gliomu subtipi, kurus raksturo atšķirīgas molekulāras un proteīnu ekspresijas signatūras (Motomura et al., 2012; Parsons et al., 2008; Verhaak et al., 2010). Piemēram, Verhaak et al., veicot plašu, lielapjoma gēnu ekspresijas profilēšanu, atklāja četrus bioloğiski 
atšķirīgus GBM molekulāros subtipus - klasisko, proneirālo, mezenhimālo un neirālo subtipu (Verhaak et al., 2010). Audzējus ar līdzīgām molekulārām signatūrām un gēnu ekspresijas profiliem, visticamāk, apvieno kopīga patogienēze, un zināšanas par to potenciāli varētu tikt izmantotas jaunas mērḳterapijas izstrādei, kā arī ieviestu jaunus prognostiskus un predikatīvus faktorus, padarot ārstēšanu vairāk personalizētu.

Gliomu molekulārā profilēšana ir ḷoti laikietilpīgs un dārgs process, kas nav piemērojams ikdienas klīniskajā praksē. Praktiskiem mērķiem imūnhistoḳīmija (IHĶ) joprojām paliek kā ērts un nozīmīgs līdzeklis prognostisko faktoru izvērtēšanā klīniskajā vidē, jo metode ir daudz lētāka un vieglāk veicama. Pēdējo gadu molekulārie atklājumi paver arī plašākas iespējas IHĶ izmantošanai, piemēram, imūnhistoḳīmiska IDH1 R132H mutācijas noteikšana gliomās tagad ir plaši pieejama arī rutīnas praksē.

Vairāki autori ir veiksmīgi mēǵinājuši veikt GBM subtipēšanu, izmantojot IHĶ metodi (Le Mercier et al., 2012; Popova et al., 2014; Trabelsi et al., 2016).

Šajā pētîjumā tika izmantota IHĶ, lai izvērtētu vairākas audzēja biologiskās pamatīpašības (invāzija, proliferācija, šūnas cikla regulācija) nosakošu proteīnu ekspresiju un savstarpējās korelācijas. Kā arī iedvesmojoties no Verhaak et al. aprakstītās gliomu klasifikācijas, tika mēǵināts ar IHĶ palīdzību, izmantojot par pamatu jau aprakstītās molekulārās signatūras, atšķirt šīs gliomu grupas un raksturot to prognostisko vai prediktīvo nozīmi.

\subsection{Kopējā izdzīvotība}

Šajā pētījumā GBM pacientu mediānais izdzīvotības laiks bija 7,9 (95\% TI = 6,8-9,0) mēneši, kas kopumā ir nedaudz īsāks, salīdzinot ar vairāku citu autoru pētījumiem, kuros mediānais izdzìvotības laiks bija intervālā no 9,7 līdz 13,6 mēnešiem (Back et al., 2007; Johnson and O'Neill, 2012; Kumar et al., 2013; Ulutin et al., 2006). Šajā pētījumā bija tikai divi $(1,5 \%$; $95 \%$ TI $=0-5,8)$ 
GBM pacienti, kuri izdz̄̄voja ilgāk par trim gadiem. Visgarākais izdzīvotības laiks bija 56 mēneši jeb 4,6 gadi. Šajā pētījumā viena un divu gadu izdzīvotības rādītāji bija 36,3 \% un 9,6 \%, kas arī ir nedaudz mazāki, salīdzinot ar citām publikācijām (Ahmadloo et al., 2013; Ma et al., 2009; Paszat et al., 2001; Scoccianti et al., 2010).

Pacientiem ar DA bija daudz labāka prognoze, salīdzinot ar GBM. Šajā pētījumā divu un trīs gadu izdzīvotības rādītāji DA pacientiem bija $88 \%$ un 80 \%. Mediāno izdzìvotības laiku DA pacientiem nevarēja aprēķināt sakarā ar īso novērošanas laiku un mazu pētāmo grupu. Pētnieki no ASV (Mejo klīnikas; Mayo Clinic), veicot apjomīgu izdzīvotības laika analīzi pacientiem ar difūzām gliomām, kur mediānais novērošanas laiks bija 13,6 gadi, konstatēja, ka DA mediānais izdzīvotības laiks bija 6,9 gadi, kā arī 10 gadu dzīvildze bija $36 \%$ (Schomas et al., 2009). Šajā pētījumā mediānais novērošanas laiks gliomu pacientiem bija 60,2 mēneši jeb 5,0 gadi. Kas ir adekvāts novērošanas laiks GBM pacientiem, kuriem ir ḷoti slikta prognoze. Taču pacientiem ar DA precīzākai izdzīvotības analīzei vēlams ilgāks novērošanas periods.

\subsection{Klīniskie un morfoloğiskie parametri}

\section{Dzimums}

Šis pētījums analogi citiem apstiprina, ka gan GBM, gan DA vienādi bieži attīstās vīriešiem un sievietēm. Dažos pētījumos ir aprakstīta nedaudz biežāka gliomu attīstība vīriešiem, tomēr lielākajā dạ̦ā pētījumu dzimumatšķirības ir niecīgas un vīriešu/sieviešu attiecība nepārsniedz 1,3 (Dobes et al., 2011; Kushnir and Tzuk-Shina, 2011; Sun et al., 2015). Arī izdzīvotības rādītāji starp dzimumiem neatšķiras, kas nav pretrunā ar citu autoru pētījumiem. Ir daži pētījumi, kuros konstatēta nedaudz labāka prognoze vīriešu pacientiem, tomēr 
daudzfaktoru analīze parādīja, ka sievietes pētāmajā grupā bija vecākas, kas arī varētu izskaidrot šādas atšķirības (Tugcu et al., 2010; Verger et al., 2011).

\section{Vecums}

Šajā pētījumā GBM un DA pacientu vidējais vecums bija atbilstoši 62,0 un 37,5 gadi, kas atbilst citu autoru datiem (Oszvald et al., 2012; Schomas et al., 2009; Schwartzbaum et al., 2006). Šajā pētījumā bija 5 pacienti ar sekundāru GBM, kuru vidējais vecums bija 50,6 gadi, kas ir nedaudz virs citos pētījumos aprakstītā vidējā vecuma sekundārām GBM, bet tajos pētījumos bija arī daudz lielāks pacientu skaits (Juratli et al., 2013; Ohgaki and Kleihues, 2007).

Šajā pētījumā lielāks pacientu vecums bija saistīts ar sliktāku prognozi, ko arī apstiprina citi autori (Buckner, 2003; Scott et al., 2012).

\section{Audzēja lokalizācija}

Šajā pētījumā biežāk sastopamā GBM lokalizācija bija pieres daiva ar 56/146 (38,4\%; $95 \% \mathrm{TI}=30,5-46,3)$ gadījumiem, tad deniṇu daiva - 41/146 $(28,1 \%$; $95 \% \mathrm{TI}=20,8-35,4)$. Šie dati ir līdzīgi citu pētījumu datiem, kur pieres daivā lokalizējās 40-43 \% audzēju, bet deniṇu daivās - 28-29\% (Larjavaara et al., 2007; Simpson et al., 1993). Pacientiem ar DA visbiežā sastopamā audzēja lokalizācija arī bija pieres un deninuu daivas, atbilstoši 13/26 (50\%; $95 \%$ TI $=30,8-69,2)$ un 6/26 (23,1 \%; $95 \%$ TI = 6,9-39,3) gadījumu, kas konstatēts arī citu autoru darbos (Capelle et al., 2013; Duffau and Capelle, 2004; Larjavaara et al., 2007).

Šajā pētījumā multifokālas GBM tika konstatētas $11 \%$ gadījumu, līdzīgi kā citos pētījumos, kuros biežums ir no 8 līdz 10 \% (Barnard and Geddes, 1987; Djalilian et al., 1999; Giannopoulos and Kyritsis, 2010). 


\section{Audzēja izmērs}

Tā kā gliomas plaši infiltrē galvas smadzeņu audus vēl pirms attīstās klīniskā simptomātika, lielākā daḷa gliomu diagnozes atklāšanas brīdī ir liela izmēra audzēji. Šajā pētījumā lielākā daḷa GBM un DA bija lieli audzēji ar izmēru virs $4 \mathrm{~cm}$. Ir salīdzinoši maz pētījumu, kuros aprakstîta saistība starp audzēja izmēru un prognozi, dažās no šīm publikācijām liels audzēja izmērs bija saistīts ar sliktāku prognozi (Kashi et al., 2015; Raysi Dehcordi et al., 2012). Arī šajā pētījumā audzēji ar izmēru virs $4 \mathrm{~cm}$ bija ar sliktāku prognozi nekā mazāki audzēji.

\section{Morfoloǵija}

Visas GBM šajā pētījumā bija diagnosticētas atbilstoši PVO CNS audzēju klasifikācijai, 2016. Morfologiski GBM raksturo nekroze (išēmiska vai/un pseidopalisadējoša) un mikrovaskulāra proliferācija. Lielākā daḷa GBM šajā pētījumā bija ar klasisku morfologiiju - 141/146 (96,6 \%; $95 \%$ TI = 93,7-99,5), bet tika konstatētas arī divas (1,4\%) gigantšūnu GBM un trīs $(2,1 \%)$ gliosarkomas. Šo reto GBM morfologisko tipu biežums ir atbilstošs citos pētījumos aprakstītajam, kur gigantšūnu GBM veidoja 2-8\%, un gliosarkomas 1-5 \% no visiem gadījumiem (Castelli et al., 2016; Kozak and Moody, 2009; Meis et al., 1991; Valle-Folgueral et al., 2008). Attiecībā uz pieciem pacientiem ar imūnhistoḳīmiski apstiprinātu sekundāru GBM (IDH1 R132H pozitīva) tikai vienā GBM gadījumā konstatēja zemākas anaplāzijas pakāpes audzēja komponenti, tādējādi apstiprinot sekundāru izcelsmi arī morfoloǵiski. Papildu tam vienā no IDH1 R132H pozitīvajiem GBM gadījumiem konstatēja fokāli palielinātu gemistocītisko astrocītu daudzumu. Atsevišşāas publikācijās minēts, ka palielinātu gemistocītu daudzumu bieži konstatē sekundārās GBM, taču tā nav droša pazīme (Reis et al., 2001; Watanabe et al., 1997). 
Visi 26 DA gadījumi bija diagnosticēti morfologiiski atbilstoši PVO CNS audzēju klasifikācijai, 2016. Visas DA šajā pētījumā bija ar zemu un vidēju celularitāti, atsevišķākas audzēja šūnas bija ar vieglām šūnu un kodolu atipijas pazīmēm, tika konstatētas retas mitozes - līdz 2 mitozēm uz 10 lielā palielinājuma redzes laukiem.

\subsection{Gliomu imūnhistoḳīmiskais profils}

\section{Ki-67}

Ki-67 proliferācijas frakcija tieši raksturo audzēju biologisko potenciālu, un palielināta proliferācija gliomas korelē ar augstāku gliomas malignitātes pakāpi (Arshad et al., 2010; Johannessen and Torp, 2006; Skjulsvik et al., 2014).

Šajā pētījumā Ki-67 proliferācijas frakcija ievērojami atšḳīrās starp GBM un DA - 44,4 \% (95 \% TI $=41,1-47,6)$ un 6,4 \% (95\% TI = 4,7-8,0). Vidèjā Ki-67 proliferācijas vērtība - 44,4 \%, GBM bija augstāka, salīdzinot ar citos pētījumos aprakstītajām - $12 \%$ to $32 \%$ (Kleinschmidt-DeMasters et al., 2005; Shivaprasad et al., 2016; Wakimoto et al., 1996).

Ki-67 proliferācijas vidējā un mediānā vērtība DA šajā pētîjumā bija 6,4 \% (95\% TI = 4,7-8,0) un 5,5 (IQR = 6). Salīdzinājumam, norvēǵu autoru pētījumā Ki-67 proliferācijas vidējās un mediānās vērtības DA bija līdzīgas atbilstoši 5,2 \% un 4,5\%, kā arī vērtību intervāls bija no $1 \%$ līdz pat $16 \%$ (Tove et al., 2012).

Attiecībā uz Ki-67 prognostisko lomu GBM dati ir ļoti pretrunīgi - ir autori, kuri apraksta Ki-67 kā nozīmīgu prognostisku faktoru (Ho et al., 2003; Jin et al., 2011), un ir pētījumi, kur tam nekonstatē prognostisku nozīmi (Moskowitz et al., 2006; Yang et al., 2013). Daudzos pētījumos tika izmantotas arī ļoti atšḳirīgas Ki-67 ekspresijas robežvērtības (piem., 12,5\%, $25 \%$, $35 \%$ u.c.) GBM pacientu izdzīvotības laika analīzē (Ho et al., 2003; Jin et al., 2011; Moskowitz et al., 2006). Šajā pētījumā, izmantojot abas robežvērtības (25\% un 
$41 \%$ ), netika konstatēta prognostiska nozīme Ki-67 proliferācijas frakcijai. Tomēr, izmantojot robežvērtību $25 \%$, vizuāli ir redzamas izdzīvotības laika līkņu atšķirības starp augstu un zemu Ki-67 proliferācijas frakciju, bet rezultāts nav statistiski ticams.

Tomēr attiecībā uz DA Ki-67 proliferācijas frakcijai ir prognostiska nozīme, kas pierādījās šajā pētījumā. Citi autori arī apstiprina Ki-67 prognostisko nozīmi zemas malignitātes gliomās, bet ne GBM (Johannessen and Torp, 2006; Tove et al., 2012).

Šajā pētījumā GBM grupā novērota korelācija starp Ki-67 proliferācijas frakciju un p53 proteīna ekspresiju $\left(r_{s}=0,196 ; p=0,027\right)$. Kā arī p27 proteīna ekspresijai bija tendence uz negatīvu korelāciju ar Ki-67. Tas varētu liecināt par to, ka p27 zudums un aberanta p53 proteīna uzkrāšanās audzēja šūnās varētu būt saistīta ar augstāku proliferatīvo potenciālu GBM šūnās.

Šajā pētījumā interesantas ir konstatētās dzimumatškirīības pacientiem ar DA - Ki-67 ekspresija bija statistiski ticami augstāka vīriešiem $(z=2,563$; $\mathrm{p}=0,010)$. Lai arī iemesls šādām dzimumatšķirībām nav īsti skaidrs, pašlaik strauji palielinās pētījumu daudzums, kuros aprakstīta dzimumhormonu loma gliomu patoǵenēzē un konstatētas atšķirības gēnu ekspresijas profilos atšķirīga dzimuma pacientiem (Hartman et al., 2009; Paruthiyil et al., 2004; Sareddy et al., 2016; Yu et al., 2013). Atsevišķos pētījumos dzimumatškirīibu pamatā ir uzsvērta iespējama estrogēna receptora beta (ERß) loma, kam pierādīta tumoru supresora aktivitāte, un šĩ receptora izzudums bieži ir saistīts ar daudzu audzēju, arī gliomu augstāku malignitātes pakāpi, un progresijas risku (Bardin et al., 2004; Burns and Korach, 2012). Taču pēc pēdējo gadu pētījumiem ir pamats domāt, ka tam ir daudz sarežğîtāka izcelsme, un gliomas starp dzimumiem var atšķirties pat pēc to molekulāriem, metilācijas un proteīnu ekspresijas profiliem (Johansen et al., 2020; Kfoury et al., 2018; Yang et al., 2019). 


\section{p53}

Normālās šūnās p53 proteīns ir sastopams nelielā daudzumā, jo tam ir ḷoti īss pussabrukšanas periods, bet TP53 gēna mutācijas var izraisīt aberanta p53 proteīna uzkrāšanos, kurš ir daudz stabilāks (Ashcroft and Vousden, 1999). Aberanta p53 proteīna klātbūtni var pierādīt imūnhistoḳīmiski kā intensīvu, nukleāru ekspresiju.

Šajā pētījumā GBM pacientiem p53 proteīna ekspresiju konstatēja 64,3\% $(95 \%$ TI = 55,6-72,1) gadījumos, izmantojot ekspresijas robežvērtību $10 \%$. Citu autoru pētījumos p53 pozitīva ekspresija, izmantojot identisku robežvērtību, variēja no $41 \%$ līdz pat $75 \%$ (Kawasoe et al., 2015; Popova et al., 2014; Takano et al., 2012). Šajā pētījumā intensīvu p53 proteīna ekspresiju virs 50 \% audzēja šūnu konstatēja 31,7 \% (95 \% TI = 24,2-40,3) gadījumos, kas atbilst arī Houillie et al. aprakstītajiem 37 \% gadījumu ar robežvērtību 50 \% (Houillier et al., 2006).

Šajā pētījumā augstu p53 ekspresiju konstatēja visos sekundāru GBM gadījumos (IDH1 R132H pozitīvas), salīdzinot tikai ar pusi no pārējiem IDH1 R132H negatīviem GBM gadījumiem, un analizējot vidējo p53 ekspresijas līmeni, tas atbilstoši bija 98,6 \% un 32,7 \%. Šo novērojumu apstiprina arī citi pētījumi, kuros konstatē augstu TP53 gēna mutāciju biežumu un augstu p53 proteīna ekspresiju sekundārās GBM (Ohgaki and Kleihues, 2007; Takano et al., 2012; Watanabe et al., 1996).

Pacientiem ar DA augsta p53 proteīna ekspresija (robežvērtība 10\%), konstatēta 75,0 \% (95 \% TI = 55,1-88,0) gadījumu, kas sakrīt ar Gillet et al., datiem - arī $75 \%$ gadījumu (Gillet et al., 2014).

Šajā pētījumā nekonstatēja p53 proteīna ekspresijas atšķirību starp GBM un DA ( $\mathrm{p}=0,416)$, kas atbilst arī citu autoru datiem (Ali and Jalal, 2013; Nayak et al., 2004). 
Ne GBM, ne DA netika arī konstatēta prognostiska nozīme p53 ekspresijai, kas nav pretrunā ar citiem pētījumiem (Houillier et al., 2006; Simmons et al., 2001; Takano et al., 2012).

Šajā pētījumā GBM pacientiem p53 proteīna ekspresija uzrādīja pozitīvu korelāciju ar Ki-67 $\left(r_{s}=0,196 ; p=0,027\right)$, PDGFRA $\left(r_{s}=0,181 ; p=0,043\right)$ un MVB $\left(\mathrm{r}_{\mathrm{s}}=0,228 ; \mathrm{p}=0,031\right)$. Attiecībā uz korelāciju starp p53 un PDGFRA gan TP53, gan PDGFRA gēnu mutācijas ir biežāk sastopamas proneirāla subtipa GBM (Verhaak et al., 2010).

\section{p21}

p21 proteīns ir svarīgs šūnas cikla inhibitors, kas iesaistīts šūnas cikla kontrolē (apoptoze, transkripcija, šūnas cikla progresija) gan normālās, gan audzēja šūnās (Coqueret, 2003). p21 proteīnam bieži var būt arī duāla loma, izraisot savstarpēji pretējus efektus, - papildus audzēju supresora efektam, tas var darboties arī kā onkoproteīns, nomācot apoptozi (De la Cueva et al., 2006; Gartel, 2006).

Šajā pētījumā vidējā p21 proteīna ekspresija GBM bija 21,2 \% (95\% TI = 18,7-23,6), kas ir loti līdzīgi citu autoru datiem (Kirla et al., 2003).

Šajā pētījumā konstatēta palielināta p21 ekspresija GBM - 49,3\% (95\% $\mathrm{TI}=41,3-57,4)$, salīdzinot ar DA - $15 \%(95 \% \mathrm{TI}=5,2-36,0)$, arī citos pētījumos apstiprinoši aprakstīta augstāka p21 ekspresija augstas malignitātes pakāpes gliomas (Zolota et al., 2008). Paradoksāli, bet augstas malignitātes audzējos, kas ir proliferatīvi aktīvāki, ir arī augstāka p21 ekspresija, kas varētu liecināt par p21, kā onkoproteīna iesaisti, iespējams, saistībā ar apoptozes nomākšanu.

Šajā pētījumā konstatēta asociācija starp samazinātu p21 ekspresiju un lielāku GBM izmēru, kas pārsniedz $4 \mathrm{~cm}(\mathrm{z}=-2,460 ; \mathrm{p}=0,014)$. Šo asociāciju arī papildina negatīva korelācija starp p21 ekspresiju un lielāko audzēja izmēru 
$\left(\mathrm{r}_{\mathrm{s}}=-0,181 ; \mathrm{p}=0,045\right)$. Šie novērojumi liecina, ka samazināta $\mathrm{p} 21$ ekspresija var veicināt ātrāku audzēja augšanu, kas nav pretrunā ar p21 galveno funkciju, t.i., audzēju supresora proteīna efektu un spēju inhibēt šūnas ciklu (Abbas and Dutta, 2009; Warfel and El-Deiry, 2013).

Pacientiem ar DA tika konstatēta arī pozitīva korelācija starp p21 un $\operatorname{MVB}\left(\mathrm{r}_{\mathrm{s}}=0,448 ; \mathrm{p}=0,049\right)$, kas varētu liecināt par p21 iesaisti arī angioǵenēzes procesā. Vairāku autoru pētījumos papildu anti-apoptotiskam efektam ir aprakstìts arī no p21 atkarīgs, angioǵenēzi veicinošs efekts audzēja šūnās, kas varētu būt kā logisks pamatojums šādai korelācijai (Kuljaca et al., 2009; Lee et al., 2010).

p27 ir ciklīna-ciklīna atkarīgās kināzes inhibitors un audzēju supresors, kas spēj apturēt šūnas cikla progresiju (Moller, 2000). Audzēju šūnās p27 ekspresija parasti ir samazināta, kas ir saistīts ar tā modifikāciju postranslācijas līmen̄i un palielinātu p27 degradāciju proteosomās (Bloom and Pagano, 2003; Piva et al., 1999).

Šajā pētījumā p27 proteīna ekspresija GBM bija konstatēta 60,1\% (95\% $\mathrm{TI}=50,9-68,7)$ gadījumu, kas ir ļoti tuvs rezultāts cita pētnieka iegūtajiem 57,2 \%, izmantojot analogu robežvērtību (Yang et al., 2011). Savukārt pacientiem ar DA p27 ekspresija bija ievērojami augstāka - 86,9 \% (95\% $\mathrm{TI}=67,8-95,4)$ gadījumu, un arī šis rezultāts ir līdzīgs divos citos pētījumos aprakstītajām p27 ekspresijas vērtībām DA - 92,8 \% un 81,2 \% (Faria et al., 2007; Yang et al., 2011). N̦emot vērā iepriekš minēto, var secināt, ka p27 ekspresijas zudums ir saistīts ar augstāku audzēja malignitātes pakāpi, ko apstiprina arī liela dą̧a pētījumu (Faria et al., 2007; Kirla et al., 2003; Yang et al., 2011; Zolota et al., 2008). Turklāt šajā pētījumā tika konstatēta arī tendence uz negatīvu korelāciju $\left(\mathrm{r}_{\mathrm{s}}=-0,199 ; \mathrm{p}=0,055\right)$ starp p27 un Ki-67 indeksu 
pacientiem ar GBM, kas vēlreiz liecina par to, ka p27 ekspresijas zudums ir saistīts ar audzēja agresīvāku un proliferatīvi aktīvāku fenotipu. Negatīvu korelāciju starp p27 un Ki-67 gliomās apstiprina arī citi autori (Cavalla et al., 1999; Fuse et al., 2000; Kirla et al., 2003).

p27 proteīna ekspresijā konstatēta arī interesanta asociācija ar pacienta dzimumu, tādējādi p27 ekspresija bija pārliecinoši zemāka sievietēm $(\mathrm{z}=-2,174 ; \mathrm{p}=0,030)$. Vērtējot šo asociāciju, daudzu citi autoru publicētajos pētījumos nav atrasta informācija attiecībā uz p27 ekspresijas dzimumatšķirībām gliomās, taču šis rezultāts nav pretrunā ar Huang et al. novērojumiem par to, ka estrogēni veicina, savukārt progesterons inhibē ubikvitīna-proteosomu sistēmas atkarīgu, nukleāra p27 proteīna destrukciju, kas pētīta endometrija vēža šūnās (Huang et al., 2012).

\section{CD44}

CD44 ir transmembranozs glikoproteīns, kas piedalās adhēzijā starp šūnām, kā arī starp šūnām un ekstracelulāro matriksu, piesaistot hialuronskābi (Dzwonek and Wilczynski, 2015; Naor et al., 1997). CD44 membranozā lokalizācija un izteiktā afinitāte uz ekstracelulārā matriksa komponentiem kā hialuronskābi veicina audzēja šūnu invāziju un migrāciju (Bradshaw et al., 2016). CD44 piesaistīšanās hialuronskābei, iespējams, veicina audzēja progresiju arī saistībā ar citiem mehānismiem, tādiem kā tirozīnkināzes un specifisku intracelulāru signālceḷu aktivācija (Mooney et al., 2016; Shepard, 2015; Thapa and Wilson, 2016). CD44 molekulai ir atklātas vairākas izoformas, kas veidojas alternatīvā splaisinga un sekojošu posttranslācijas mehānismu rezultātā, līdz ar to šai molekulai raksturīga liela funkcionāla daudzveidība (Prochazka et al., 2014). CD44 ir arī viens no vēža cilmes šūnu marḳieriem dažādos audzējos, tai skaitā arī gliālajos. Attiecībā uz centrālo nervu sistēmu CD44 tiek aprakstîts kā markieris neirālām cilmes šūnām, kā arī astrocītu un 
oligodendrocītu priekštečiem (Liu et al., 2004; Naruse et al., 2013). Daži autori uzskata, ka CD44 ir neirālu cilmes šūnu marķieris, kas ekspresējas daḷēji diferencētās, vēl nenobriedušās šūnās (Bradshaw et al., 2016).

CD44 ir iesaistīts audzēja šūnu mezenhimālajā transformācijā, veicinot invāziju (Xu et al., 2015). Gliomu molekulārajā klasifikācijā CD44 ir aprakstīts kā mezenhimāla GBM subtipa marķieris (Phillips et al., 2006; Verhaak et al., 2010). CD44 ekspresijas imūnhistoḳīmiska noteikšana ir ieteikta vairāku autoru pētījumos, veicot gliomu molekulāru subtipēšanu, kā ērta un vienkārša metode mezenhimāla subtipa identifikācijai (Popova et al., 2014).

Šajā pētījumā CD44 ekspresija bija ḷti atkarīga no audzēja malignitātes pakāpes, GBM tā bija daudz augstāka nekā DA - vidējā ekspresija GBM bija $74,1 \%(95 \% \mathrm{TI}=69,6-78,7)$, salīdzinot ar 13,5 \% (95\% TI = 7,7-19,2) DA. Augsta CD44 ekspresija (virs $50 \%$ ) tika konstatēta lielākajai daliai GBM 81,5 \% (95 \% TI = 74,4-86,9) gadījumos, savukārt šāds ekspresijas līmenis bija sasniegts, bet ne pārsniegts, tikai vienā no DA gadījumiem. Daudzi autori arī novēroja daudz augstāku CD44 ekspresiju augstas malignitātes pakāpes gliomās, piemēram, Popova et al., konstatēja CD44 ekspresiju GBM un DA atbilstoši $42 \%$ un $15 \%$, bet Ranuncolo et al. $-59 \%$ un 9,5\% (Popova et al., 2014; Ranuncolo et al., 2002).

Ir maz pētījumu, kuros tiek aprakstīts CD44 ekspresijas raksturs. Šajā pētījumā visintensīvāko CD44 ekspresiju novēroja GBM, kur pārsvarā bija membranoza, difūza ekspresija. Līdzīgu membranozu ekspresiju novēroja tikai nelielā daḷā DA, kur šāda ekspresija bija fokāla, sīkperēkḷaina un mazākas intensitātes, salīdzinot ar GBM. CD44 ekspresijas dominējošais raksturs DA pārsvarā bija citoplazmisks, mazintensīvs, lielākoties lokalizēts daudzajos sazarotajos astrocītu izaugumos, veidojot smalku, zemas intensitātes CD44 imūnreaktivitātes tīklojumu. Š̀̃ vājā fona imūnreaktivitāte astrocītu izaugumos šajā pētījumā netika ņemta vērā CD44 ekspresijas kvantitatīvai raksturošanai, 
taču šādu specifisku ekspresijas raksturu ir vērts pieminēt kā atsevišķu DA raksturīgu ekspresiju. Vienā citā pētījumā arī ir aprakstīts līdzīgs ekspresijas raksturs: membranoza ekspresija GBM, bet vāja citoplazmiska ekspresija astrocītu izaugumos DA (Jijiwa et al., 2011). Interesanti, bet daži autori konstatējuši analoga rakstura vāju CD44 ekspresiju dažu astrocītu fibrilārajos izaugumos arī normālos galvas smadzeņu audos (Kaaijk et al., 1997; Sosunov et al., 2014). Kaaijk et al. izvirzīja hipotēzi, ka CD44 ekspresija normālos astrocītos varētu veicināt reaktīvu astrocītu migrāciju iekaisuma vai cita galvas smadzeņu audu bojājuma gadījumā (Kaaijk et al., 1997). Taču Lui et al. parādīja, ka CD44 ekspresija ḷauj identificēt astrocītu cilmes šūnas (Liu et al., 2004). Arī daudzos citos pētījumos CD44 ir aprakstīts kā astrocītu priekšteču šūnu marķieris (Cai et al., 2012; Malik et al., 2014; Naruse et al., 2013).

Šajā pētījumā netika konstatēta prognostiska nozīme CD44 ekspresijai ne GBM, ne DA. Tomēr augsta CD44 ekspresija kopā ar zemu p53, PDGFRA un IDH1 ekspresiju tika izmantota kā mezenhimāla GBM subtipa marķieris, kur tika konstatēts, ka mezenhimālu GBM subtipu raksturo slikta atbildes reakcija uz radioterapiju. Tādējādi, CD44 ekspresija kombinācijā ar proneirāla subtipa marḳieriem (p53, PDGFRA, IDH1) var būt labs predikatīvs marḳieris.

Šajā pētījumā augstāku CD44 ekspresiju konstatēja sievietēm $(\mathrm{z}=-2,224 ; \mathrm{p}=0,026)$, kas var liecināt, ka gliomas cilmes šūnu populāciju var ietekmēt no dzimuma atkarīgi faktori. Kāa arī tika konstatēta vāja, bet statistiski ticama negatīva korelācija ar GBM izmēru $\left(r_{s}=-0,314 ; p<0,001\right)$. Šo korelāciju arī pastiprina asociācija, ka zemāku CD44 ekspresiju biežāk konstatē lielāka izmēra audzējos (virs $4 \mathrm{~cm})(\mathrm{z}=-2,364 ; \mathrm{p}=0,018)$. Un tas varētu liecināt, ka strauja audzēja augšana var izraisīt cilmes šūnu populācijas samazināšanos gliomās.

Šajā pētījumā DA grupā bija konstatēta vidēji stipra, negatīva korelācija starp CD44 un PDGFRA $\left(r_{s}=-0,592 ; p=0,006\right)$. Arī citi autori apstiprina šādu 
saistību starp abiem marķieriem, Conray et al. pētījumā konstatēts novērojums, ka augsti CD44 ekspresijas rādītāji reti tiek konstatēti gliomās ar augstu PDGFRA ekspresiju (Conroy et al., 2014). N̦emot vērā to, ka dažādos pētījumos aprakstītais PDGFRA aktivācijas signālceḷš ir saistīts ar GBM proneirāla subtipa attīstību, savukārt CD44 ekspresija raksturo mezenhimālu subtipu, kas ir cits gliomas tips, šāda negatīva korelācija ir logiiska.

DA grupā ir novērota arī pozitīva korelācija starp CD44 un MVB $\left(r_{s}=0,490 ; p=0,018\right)$, kas var norādīt uz gliomas cilmes lomu vaskularizācijas veicināšanā, tādējādi uzlabojot audzēja asinsriti, kas nepieciešama gliomas augšanai un progresijai. Par labu šim pieņēmumam liecina arī citu autoru pētījumos konstatētie pierādījumi tam, ka gliomas cilmes šūnas patiešām sekretē vairākas angiogēnās vielas, veicinot jaunu asinsvadu veidošanos (Bao et al., 2006; Hardee and Zagzag, 2012).

\section{PDGFRA}

Trombocītu atbrīvotā augšanas faktora receptors alfa (PDGFRA) ir šūnas virsmas tirozīnkināzes receptors trombocītu atbrīvotajiem augšanas faktoriem (PDGF). Daudzos pētījumos ir pierādīts, ka PDGFRA molekulai ir liela nozīme nobriedušu oligodendrocītu veidošanās procesā no mazāk diferencētām oligodendrocītu priekšteču šūnām vai pat multipotentām neirālām cilmes šūnām. Šo multipotentu cilmes šūnu stimulācija ar PDGF-alfa nosaka to diferenciācijas virzienu un nobriešanu par termināli diferencētiem oligodendrocītiem (Fruttiger et al., 1999; Hu et al., 2008).

PDGFRA signālceḷam ir arī svarīga loma gliomu attīstībā. Palielināta PDGFA aktivitāte stimulē vēl nenobriedušu priekšteču šūnu proliferāciju un kavē to spēju nobriest un diferencēties par termināli diferencētām šūnām, turpinoties šo šūnu proliferācijai, var attīstīties gliomas (Jackson et al., 2006). 
Turklāt pēc Verhaak et al. aprakstītās gliomu molekulārās klasifikācijas PDGFRA gēna amplifikācija kopā ar IDH1 un TP53 gēnu mutācijām raksturo proneirālu GBM subtipu (Verhaak et al., 2010).

Šajā pētījumā PDGFRA vidējā ekspresija DA bija daudz augstāka - 42,3 $(95 \% \mathrm{TI}=25,7-59,0)$ gadījumi, salīdzinot ar GBM - 7,9 (95\% TI = 5,0-10,7) gadījumi. Augsta PDGFRA ekspresija (robežvērtība 50 \%) tika konstatēta $50 \%$ $(95 \% \mathrm{TI}=30,1-75,0)$ DA gadījumu, salīdzinot ar 6,2 \% (95 \% TI = 3,2-11,3) GBM gadījumu. Iegūtie dati ir salīdzināmi ar citiem pētîjumiem, kur arī PDGFRA ekspresija bija ievērojami augstāka DA, piemēram, Popova et al. pētījumā augsta ekspresija bija $23 \%$ DA un tikai 4 \% GBM (Popova et al., 2014).

Šajā pētījumā PDGFRA ekspresija uzrādīja arī pozitīvu korelāciju ar p53 gan GBM $\left(r_{s}=0,181 ; p=0,043\right)$, gan DA $\left(r_{s}=0,544 ; p=0,013\right)$. Šāda korelācija starp PDGFRA un p53 bija aprakstīta arī Popova et al. publikācijā (Popova et al., 2014). Kā jau bija minēts iepriekš, TP53 un PDGFRA gēnu mutācijas raksturīgas GBM proneirālajam subtipam (Verhaak et al., 2010). Līdz ar to p53 un PDGFRA savstarpēja korelācija var norādīt uz šo abu proteīnu ciešu funkcionālu saikni gliomās, iespējams, TP53 un PDGFRA gēna mutācijas ir svarīgas noteikta tipa gliomu agrīnā attīstībā, bet precīzi mehānismi šādai korelācijai nav zināmi.

Šajā pētījumā ir novērota negatīva korelācija starp PDGFRA un CD44 $\left(r_{s}=-0,592 ; p=0,006\right)$, ņemot vērā to, ka katrs no šiem proteīniem raksturo atsevišķu gliomas subtipu (t. i., proneirālo un mezenhimālo) šāda korelācija ir loǵiska, kas arī liecina par divu savstarpēji izslēdzošu gliomu subtipu eksistenci.

Papildu iepriekšminētajai korelācijai, konstatēja arī negatīvu korelāciju DA starp PDGFRA un MVB $\left(\mathrm{r}_{\mathrm{s}}=-0,501 ; \mathrm{p}=0,034\right)$. Precīzs izskaidrojums šādai saistībai nav zināms, bet, atsaucoties uz vienu citu negatīvu korelāciju starp PDGFRA un CD44 ( $\left.\mathrm{r}_{\mathrm{s}}=-0,592 ; \mathrm{p}=0,006\right)$, varētu hipotētiski secināt, ka palielināta PDGFRA ekspresija nomāc gliomas cilmes šunu populāciju, kas 
samazina šo pašu cilmes šūnu angiogēno faktoru sekrēciju, tādējādi ietekmējot vaskularizāciju.

\section{IDH1 R132H}

Izocitrātdehidrogenāze (IDH) ir metabols enzīms, kurš piedalās citronskābes ciklā. Šim enzīmam ir zināmas trīs izoformas: IDH1, IDH2 un IDH3. IDH1 gēna mutācijas gliomās ir visizplatîtākās, no tām visbiežāk sastopamā ir IDH1 R132H mutācija, kas veicina enzīma - onkometabolīta-2-hidroksiglutarāta produkciju, veicinot gliomu attīstību (Garber, 2010; Ward et al., 2012).

IDH1 gēna mutācijas ir ḷoti agrīns parādība gliomu attīstības procesā, un tās raksturo lielāko daḷu DA un sekundāru GBM. Imūnhistoḳīmiska IDH1 $\mathrm{R} 132 \mathrm{H}$ proteīna noteikšana mūsdienās ir kḷuvusi par rutīnas praksi gliomu diagnostikā, tā klātbūtne l̦auj arī atšķirt primāras (IDH1 negatīvas) no sekundārām (IDH1 pozitīvas) GBM. Kopumā sekundāras GBM veido 6-13 \% no visām GBM (Ohgaki and Kleihues, 2013). Šajā pētījumā sekundāru GBM bija mazāk (3,4 \%; 95 \% TI = 0,5-6,3). Iespējams, tas varētu būt saistīts ar pētījuma dizainu, respektīvi, šajā pētījumā netika iekḷauti recidivējoši audzēji, tādējādi visas GBM pēc klīniskās gaitas atgādināja primāras GBM. Pētījumā nebūtu loǵiski iekḷaut audzēju recidīvus, jo ir zināms, ka iepriekš saņemta terapija var būt jaucējfaktors, kas ietekmē gliomas molekulārās īpašības (Parsons et al., 2008; Safa et al., 2015; Shankar et al., 2014). Arī citos pētījumos, kuros pētāmā grupa bija veidota tikai no pacientiem ar primāriem audzējiem, kas vēl nav saṇēmuši terapiju, bija iegūts līdzīgs sekundāru GBM biežums - 3,7 \% un $3 \%$ (Le Mercier et al., 2012; Nobusawa et al., 2009).

IDH1 R132H klātbūtni DA konstatēja 76,9\% (95\% TI = 60,7-93,1) gadījumu. Šis rezultāts arī atbilst citu autoru pētījumiem, kuri apraksta, ka IDH1 mutāciju biežums DA ir $80 \%$ un $87 \%$ (Christensen et al., 2011; Juratli et al., 2012), turklāt visbiežāk sastopamo specifisko mutāciju - IDH1 R132H - 
konstatē 57-80 \% zemas malignitātes gliomu (Cai et al., 2016; Popova et al., 2014; Wang et al., 2016).

IDH1 gēna mutācijas klātbūtne gliomās ir pašlaik viens no vislabākajiem zināmajiem prognostiskajiem faktoriem, kas saistīts ar ievērojami labāku prognozi (Gravendeel et al., 2010; Nobusawa et al., 2009; Parsons et al., 2008; Sanson et al., 2009). Piemēram, mediānas izdż̄votības laiki pacientiem ar GBM, kas satur IDH1 gēna mutāciju un bez mutācijas, ir atbilstoši 3,8 un 1,1 gadi (Parsons et al., 2008). Šajā pētījumā IDH1 R132H pozitīviem GBM pacientiem ar IDH1 R132H negatīviem, mediānās izdzīvotības laiki bija atbilstoši 18,3 $(95 \% \mathrm{TI}=18,0-18,5)$ un 7,7 $(95 \% \mathrm{TI}=6,3-9,0)$ mēneši $(\mathrm{p}=0,040)$.

Šajā pētījumā, konstatēta arī asociācija starp IDH1 un p53 (z = -3,555; p = 0,001), tādējādi visās sekundārās GBM bija konstatēta ḷoti augsta aberanta p53 proteīna ekspresija. Arī citi pētîjumi apstiprina to, ka IDH1 gēna mutācijas bieži kombinējas ar citām genētiskām izmaiņām, īpaši TP53 gēna mutācijām (Huang, 2019). Turklāt gan IDH1, gan TP53 gēnu mutācijas raksturo vienu un to pašu GBM subtipu - proneirālo (Verhaak et al., 2010).

\section{MVB (CD34)}

Pastiprināta angioǵenēze ir viena no galvenajām audzēju pamatīpašībām (Hanahan and Weinberg, 2000), un CD34 kā endotēlija šūnu marķieris angioǵenēzes pētījumos bieži tiek izmantots mikrovaskulārā blīvuma noteikšanai (Foote et al., 2005; Weidner, 2008). Salīdzinoši viegla un efektīva kvantitatīva metode MVB noteikšanai audzējos (pēc Veidnera) bija ieviesta jau sen un līdz šim brīdim tiek plaši izmantota daudzos pētījumos (Weidner et al., 1991).

Šajā pētîjumā vidējās MVB vērtības GBM bija daudz augstākas, salīdzinot ar DA, atbilstoši 40,7 (95\% TI = 35,8-45,6) un 18,1 (95\% TI = 12,9-23,3). Šie rezultāti ir atbilstoši citos pētījumos aprakstītajiem, piemēram, 
Zhang et al. konstatētais MVB bija $45 \pm 6,2-$ GBM un $28 \pm 7,2-$ DA (Zhang et al., 2014).

MVB šajā pētījumā neietekmēja prognozi ne GBM, ne DA pacientiem. MVB nav bieži analizēts parametrs daudzajos gliomu pētījumos, daḷa no autoriem apgalvo, ka MVB nav prognostiskas nozīmes gliomu pacientiem (Abdulrauf et al., 1998; Leon et al., 1996). Taču nesen veiktajā metaanalīzē, apkopojot vairākus pētījumus, konstatēts, ka MVB parametrs nav pietiekoši novērtēts un ka tam varētu būt prognostiska nozīme gliomās, līdz ar to ir nepieciešami tālāki pētījumi (Fan et al., 2019).

\subsection{Gliomu subtipi}

Ilgi pirms tika aprakstīti gliomu molekulārie subtipi Verhaak et al. pētījumā, bija zināms par divu atšķirīgu GBM veidu eksistenci, kas atspoguḷo arī atšķirīgus gliomu attīstības patoǵenētiskos mehānismus, t. i., primārās GBM, kuras attīstās de novo, savukārt sekundārās GBM attīstās no zemākas malignitātes pakāpes gliomas tās malignas transformācijas rezultātā (Kleihues and Ohgaki, 1999). Abi GBM subtipi ir morfoloǵiski identiski, mūsdienās IDH mutāciju testēšana ḷauj atšķirt šos subtipus. Tādējādi GBM ar vienādu morfologiju nav viendabīga audzēju grupa, bet ir atšķirīgas pēc to molekulārajiem parametriem un arī prognozes.

Izpratne par gliomu molekulārajām īpatnībām mūsdienās ir uzlabojusies, pateicoties vairākiem apjomīgiem pētījumiem, īpaši daudz datu par molekulārajām izmaiṇām gliomās iegūts Vēža genoma atlanta (TCGA) projekta ietvaros. TCGA projektā ir iegūta visaptveroša informācija par apmēram 33 dažādu ḷaundabīgu audzēju veidu genomiskajām izmaiņām, šajā pētījumā ir iekḷauta ar̄̄ liela GBM pacientu grupa, kur šī audzēja šūnās veica plašu molekulāru testēšanu, piemēram, visa genoma sekvencēšanu, transkriptoma un metiloma analīzi, tādējādi iegūstot apjomīgu informāciju par molekulārajām 
izmain̄ām gliomās. Verhaak et al., analizējot TCGA projekta ietvaros iegūtos datus, atklāja, ka GBM var iedalīt 4 molekulārajos subtipos pēc to molekulārajām izmain̄ām un gēnu ekspresijas signatūrām - klasiskais, mezenhimālais, proneirālais un neirālais subtips (Verhaak et al., 2010).

Klīniskā praksē visērtāk būtu veikt molekulāro subtipēšanu, izmantojot pieejamu un lētāku metodi, piemēram, imūnhistoḳīmiju. Balstoties uz Verhaak et al. aprakstītajām molekulārām signatūrām, vairāki pētnieku kolektīvi ir veiksmīgi izmantojoši IHĶ metodi gliomu molekulārajā subtipēšanā (Conroy et al., 2014; Le Mercier et al., 2012; Motomura et al., 2012; Popova et al., 2014).

Vienā no imūnhistoḳīmiskiem gliomu pētîjumiem, kuru veica Le Mercier et al., klasiskais un proneirālais GBM subtips bija noteikts, izmantojot minimālu IHĶ marķieru paneli - p53, EGFR un PDGFRA, un visi audzēji, kas neiekḷāvās kādā no kategorijām, tika pieskaitīti pie neklasificēta subtipa (Le Mercier et al., 2012). Šajā pētījumā tika izmantota līdzīga pieeja, balstoties uz Verhaak et al. GBM klasifikāciju, subtipēšanas nolūkos tika noteikta PDGFRA, IDH1 R132H, p53 un CD44 ekspresija, ar mērḳi izšķirt proneirālo un mezenhimālo GBM subtipu. Mūsu pieeja bija balstìta uz to, ka TP53, IDH1 un PDGFRA gēnu mutācijas bieži atrod proneirālajā subtipā, bet ne mezenhimālajā, kuru savukārt raksturo augsta CD44 ekspresija (Verhaak et al., 2010).

Šajā pētījumā $50 \%(95 \%$ TI = 42,0-58,0) no gadījumiem tika klasificēti kā proneirālas GBM, kas ir nedaudz mazāk nekā Le Mercier et al. IHĶ subtipēšanas mēǵinājumā, kur proneirāls subtips bija konstatēts $60 \%$ no GBM gadījumiem. Popova et al. pētījumā proneirāls subtips konstatēts tikai 29 \% no GBM gadījumiem, bet šajā pētijumā bija izmantots cits proneirāla subtipa marḳieris - OLIG2 kombinācijā ar p53 ekspresijas noteikšanu. Šajā pētījumā mezenhimāls GBM subtips bija konstatēts 18,5 \% (95 \% TI = 13,0-25,6) no GBM gadījumiem. Citos pētijumos mezenhimāla subtipa biežums bija no 12 līdz 29 \%, kas bija noteikts, izmantojot 
dažādus mezenhimāla tipa marḳierus - CD44, MERTK, VIM, YKL40 (Conroy et al., 2014; Popova et al., 2014; Verhaak et al., 2010).

Šajā pētījumā netika konstatētas statistiski ticamas asociācijas starp GBM subtipu un klīniskiem vai citiem pētītajiem imūnhistoḳīmiskiem parametriem (t. i., MVB, Ki-67, p27, p21). Šajā pētījumā pacientiem ar dažādiem GBM subtipiem netika konstatētas statistiski ticamas izdzīvotības laika atšķirības. Savukārt citos pētījumos mezenhimālajam GBM subtipam bija sliktāka prognoze, salīdzinot ar proneirālo tipu (Lin et al., 2014; Phillips et al., 2006; Verhaak et al., 2010).

Lai arī prognostiskā nozīme neapstiprinājās, tomēr šajā pêtījumā tika konstatēts, ka pacienti ar proneirālo un mezenhimālo subtipu atšķirīgi reaǵē uz adjuvantu terapiju. Tādējādi pacientiem ar proneirālo subtipu tika konstatēta tendence uz izdzīvotības laika uzlabošanos pēc adjuvantas ķīmijterapijas pievienošanas radioterapijai, salīdzinot tikai ar radioterapiju $(\mathrm{p}=0,061)$. Proneirāla subtipa pacientiem, kuri saņēma tikai adjuvantu radioterapiju, bija statistiski ticama izdzīvotības laika uzlabošanās, salīdzinot tikai ar ķirurğisku ārstēšanu $(\mathrm{p}=0,008)$. Mezenhimāla subtipa pacientiem adjuvantas ķīmijterapijas pievienošana statistiski ticami uzlaboja izdzīvotības laiku $(\mathrm{p}=0,002)$, taču adjuvantas radioterapijas pievienošana ķirurǵiskai ārstēšanai neuzlaboja pacientu prognozi, salīdzinot tikai ar ķirurǵisku ārstēšanu $(\mathrm{p}=0,857)$, kas varētu norādīit uz mezenhimāla subtipa radiorezistenci. GBM mezenhimāla subtipa radiorezistence ir apstiprināta arī dažu citu autoru pētījumos, piemēram, Brown et al. arī mezenhimāla subtipa GBM konstatēja izteiktu radiorezistenci, bet saglabātu jutību pret ķīmijterapiju (Brown et al., 2015). Daži autori apraksta, ka GBM mezenhimālu subtipu raksturo cilmes šūnu fenotips, kurš ir bagātināts ar cilmes šūnu marķieri CD44 (Cheng et al., 2012), bet savukārt mezenhimālas cilmes šūnas raksturo izteikta radiorezistence (Mao et al., 2013; Nakano, 2015), kas arī varētu šajā pētījumā skaidrot radioterapeitiskā efekta izzudumu 
mezenhimālā subtipa GBM. Vairākos citos pētījumos arī ir konstatēta mezenhimālā subtipa radiorezistence, vienā no pētījumiem, kas veikts izmantojot eksperimentālu gliomas modeli pelei, ir izdevies izdalīt un pat kultivēt mezenhimālā subtipa cilmes šūnas, kas arī uzrādīja izteiktu radiorezistenci (Mao et al., 2013).

Attiecībā uz DA lielākā daḷa no zemas malignitātes pakāpes gliomu ir bagātinātas ar proneirālam subtipam raksturīgiem marḳieriem (Cooper et al., 2010; Guan et al., 2014). Kā arī augstais IDH1 mutāciju biežums DA norāda uz piederību proneirālam subtipam, kas DA ir dominējošais (Kim et al., 2010). Arī šajā pētījumā lielākā daḷa no DA - 24/26 (92,3 \%; 95 \% TI = 75,8-97,9) piederēja proneirālajam subtipam, atlikušos divus gadījumus neizdevās klasificēt. 


\section{Secinājumi}

1. GBM pacientus pētāmajā grupā raksturo slikta prognoze ar mediāno izdzīvotības laiku 7,9 mēneši, kas ir nedaudz zem izdzīvotības rādītājiem, salīdzinot ar citām valstīm.

2. Pacienti ar sekundāru GBM (IDH1 R132H pozitīva) ir ar ievērojami labāku prognozi, nekā pacienti ar primāru GBM, tādējādi IDH1 R132H mutācijas klātbūtne ir viens no nozīmīgākajiem prognostiskajiem faktoriem.

3. Pacientiem ar DA augsta PDGFRA ekspresija ir saistīta ar labāku prognozi.

4. CD44, p21, p27, PDGFRA un proliferācijas frakcija (Ki-67) ir no audzēja malignitātes pakāpes atkarīgi parametri, tādējādi CD44, Ki-67 un p21 ekspresija ir paaugstināta, bet p27 un PDGFRA ekspresija ir samazināta GBM. Turklāt p53 ekspresija nav atkarīga no gliomas anaplāzijas pakāpes.

5. Gliomu imūnhistoḳīmisko profilu saistībā ar p27, CD44, Ki-67 ietekmē no dzimuma atkarīgi specifiski faktori.

6. Samazināta p21 un CD44 ekspresija GBM ir saistìta ar lielāku audzēja izmēru. Savukārt multifokālās GBM biežāk konstatē p27 izzudumu un augstāku PDGFRA ekspresiju.

7. Ar šūnas cikla regulāciju saistītie proteīni (p53, p21, p27, Ki-67) ir iesaistīti molekulāros mehānismos, kas regulē proliferāciju un angioǵenēzi, par ko liecina attiecīgi konstatētās korelācijas ar Ki-67 un MVB.

8. PDGFRA ekspresija korelē p53 gan GBM, gan DA, norādot uz šo abu proteīnu funkcionālo saistību. Bet DA novēro PDGFRA negatīvu korelāciju ar CD44, p21 un MVB.

9. Gliomu subtipēšana ir iespējama ar imūnhistoķīmijas metodi, izmantojot nelielu skaitu markiieru - PDGFRA, p53, IDH1 R132H un CD44. Savukārt augsta CD44 ekspresija norāda uz mezenhimālu GBM subtipu, kuru raksturo slikta atbilde uz radioterapiju. 


\section{Praktiskās rekomendācijas}

1. Imūnhistoḳīmiska vizualizācija ir rekomendējama visam ķirurğiski rezecētam gliomu materiālam, prognostiskiem un predikatīviem mērḳiem.

2. Imūnhistoḳīmiska IDH1 R132H mutācijas noteikšana ir rekomendējama visām GBM, kur IDH1 R132H ir nozīmīgs prognostisks markiieris, kurš ḷauj atšķirt primāras no sekundārām GBM. Ieteicams veikt imūnhistoḳīmisku izmeklēšanu, izmantojot pētījuma gaitā izstrādātu protokolu.

3. Imūnhistoḳīmiska IDH1 R132H mutācijas noteikšana ir rekomendējama arī DA, kur tas var kalpot arī kā jutīgs diagnostisks tests. Sakarā ar to, ka liela daļa DA ir IDH1 R132H pozitīvas, IDH1 R132H noteikšanai var palīdzēt precīzi uzstādīta DA diagnoze, kas īpaši svarīgi mazā, ierobežotā materiāla daudzumā, piemēram, stereotaktisku biopsiju materiālā.

4. N̦emot vērā PDGFRA ekspresijas saistību nozīmi ar pacientu izdzī-votību, ir ieteicams veikt imūnhistoḳīmisku PDGFRA noteikšanu DA.

5. Gliomu imūnhistoķ̄imiskā subtipēšana ir iespējama un izmantojama ikdienas klīniskajā praksē. Īpaši liela loma varētu būt mezenhimāla GBM subtipa atšķiršanā, kuru raksturo izteikta radiorezistence. 


\section{Literatūras saraksts}

1. Abbas, T. and Dutta, A. (2009). p21 in cancer: intricate networks and multiple activities. Nat Rev Cancer, 9, 400-414.

2. Abdulrauf, S. I., Edvardsen, K., Ho, K. L., et al. (1998). Vascular endothelial growth factor expression and vascular density as prognostic markers of survival in patients with low-grade astrocytoma. J Neurosurg, 88, 513-520.

3. Ahmadloo, N., Kani, A. A., Mohammadianpanah, M., et al. (2013). Treatment outcome and prognostic factors of adult glioblastoma multiforme. J Egypt Natl Canc Inst, 25, 21-30.

4. Ali, T. and Jalal, J. (2013). Immunohistochemical expression of p53 and p21 in gliomas: a clinicopathological study. Zanco Journal of Medical Sciences, 17, 435-442.

5. Arshad, H., Ahmad, Z. and Hasan, S. H. (2010). Gliomas: correlation of histologic grade, Ki67 and p53 expression with patient survival. Asian Pac J Cancer Prev, 11, 1637-1640.

6. Ashcroft, M. and Vousden, K. H. (1999). Regulation of p53 stability. Oncogene, 18, 7637-7643.

7. Back, M. F., Ang, E. L., Ng, W. H., et al. (2007). Improved median survival for glioblastoma multiforme following introduction of adjuvant temozolomide chemotherapy. Ann Acad Med Singapore, 36, 338-342.

8. Bao, S., Wu, Q., Sathornsumetee, S., et al. (2006). Stem cell-like glioma cells promote tumor angiogenesis through vascular endothelial growth factor. Cancer Res, 66, 7843-7848.

9. Bardin, A., Boulle, N., Lazennec, G., et al. (2004). Loss of ERbeta expression as a common step in estrogen-dependent tumor progression. Endocr Relat Cancer, 11, 537-551.

10. Barnard, R. O. and Geddes, J. F. (1987). The incidence of multifocal cerebral gliomas. A histologic study of large hemisphere sections. Cancer, 60, 1519-1531.

11. Bhat, K. P., Balasubramaniyan, V., Vaillant, B., et al. (2013). Mesenchymal differentiation mediated by NF-kappaB promotes radiation resistance in glioblastoma. Cancer Cell, 24, 331-346.

12. Bloom, J. and Pagano, M. (2003). Deregulated degradation of the cdk inhibitor p27 and malignant transformation. Semin Cancer Biol, 13, 41-47.

13. Bradshaw, A., Wickremsekera, A., Tan, S. T., et al. (2016). Cancer Stem Cell Hierarchy in Glioblastoma Multiforme. Front Surg, 3, 21.

14. Brennan, C., Momota, H., Hambardzumyan, D., et al. (2009). Glioblastoma subclasses can be defined by activity among signal transduction pathways and associated genomic alterations. PLoS One, 4, e7752. 
15. Brennan, C. W., Verhaak, R. G. W., McKenna, A., et al. (2013). The Somatic Genomic Landscape of Glioblastoma. Cell, 155, 462-477.

16. Brown, D. V., Daniel, P. M., D'Abaco, G. M., et al. (2015). Coexpression analysis of CD133 and CD44 identifies Proneural and Mesenchymal subtypes of glioblastoma multiforme. Oncotarget, 6, 6267-6280.

17. Buckner, J. C. (2003). Factors influencing survival in high-grade gliomas. Semin Oncol, 30, 10-14.

18. Burns, K. A. and Korach, K. S. (2012). Estrogen receptors and human disease: an update. Arch Toxicol, 86, 1491-1504.

19. Cai, J., Zhu, P., Zhang, C., et al. (2016). Detection of ATRX and IDH1-R132H immunohistochemistry in the progression of 211 paired gliomas. Oncotarget, 7 , $16384-16395$.

20. Cai, N., Kurachi, M., Shibasaki, K., et al. (2012). CD44-positive cells are candidates for astrocyte precursor cells in developing mouse cerebellum. Cerebellum, 11, 181-193.

21. Cancer Genome Atlas Research, N. (2008). Comprehensive genomic characterization defines human glioblastoma genes and core pathways. Nature, 455 , 1061-1068.

22. Capelle, L., Fontaine, D., Mandonnet, E., et al. (2013). Spontaneous and therapeutic prognostic factors in adult hemispheric World Health Organization Grade II gliomas: a series of 1097 cases: clinical article. J Neurosurg, 118, 1157-1168.

23. Castelli, J., Feuvret, L., Haoming, Q. C., et al. (2016). Prognostic and therapeutic factors of gliosarcoma from a multi-institutional series. J Neurooncol, 129, 85-92.

24. Cavalla, P., Piva, R., Bortolotto, S., et al. (1999). p27/kip1 expression in oligodendrogliomas and its possible prognostic role. Acta Neuropathol, 98, 629-634.

25. Cheng, W. Y., Kandel, J. J., Yamashiro, D. J., et al. (2012). A multi-cancer mesenchymal transition gene expression signature is associated with prolonged time to recurrence in glioblastoma. PLoS One, 7, e34705.

26. Christensen, B. C., Smith, A. A., Zheng, S., et al. (2011). DNA methylation, isocitrate dehydrogenase mutation, and survival in glioma. J Natl Cancer Inst, 103, $143-153$.

27. Conroy, S., Kruyt, F. A., Joseph, J. V., et al. (2014). Subclassification of Newly Diagnosed Glioblastomas through an Immunohistochemical Approach. PLoS One, 9, e115687.

28. Cooper, L. A., Gutman, D. A., Long, Q., et al. (2010). The proneural molecular signature is enriched in oligodendrogliomas and predicts improved survival among diffuse gliomas. PLoS One, 5, e12548. 
29. Coqueret, O. (2003). New roles for p21 and p27 cell-cycle inhibitors: a function for each cell compartment? Trends Cell Biol, 13, 65-70.

30. De la Cueva, E., Garcia-Cao, I., Herranz, M., et al. (2006). Tumorigenic activity of p21Waf1//Cip1 in thymic lymphoma. Oncogene, 25, 4128-4132.

31. Djalilian, H. R., Shah, M. V. and Hall, W. A. (1999). Radiographic incidence of multicentric malignant gliomas. Surg Neurol, 51, 554-557; discussion 557-558.

32. Dobes, M., Shadbolt, B., Khurana, V. G., et al. (2011). A multicenter study of primary brain tumor incidence in Australia (2000-2008). Neuro Oncol, 13, 783-790.

33. Dong, Q., Li, Q., Wang, M., et al. (2019). Elevated CD44 expression predicts poor prognosis in patients with low-grade glioma. Oncol Lett, 18, 3698-3704.

34. Duffau, H. and Capelle, L. (2004). Preferential brain locations of low-grade gliomas. Cancer, 100, 2622-2626.

35. Dzwonek, J. and Wilczynski, G. M. (2015). CD44: molecular interactions, signaling and functions in the nervous system. Front Cell Neurosci, 9, 175.

36. Fan, C., Zhang, J., Liu, Z., et al. (2019). Prognostic role of microvessel density in patients with glioma. Medicine, 98, e14695-e14695.

37. Faria, M. H., Patrocinio, R. M., Moraes Filho, M. O., et al. (2007). Immunoexpression of tumor suppressor genes p53, p21 WAF1/CIP1 and p27 KIP1 in humam astrocystic tumors. Arq Neuropsiquiatr, 65, 1114-1122.

38. Foote, R. L., Weidner, N., Harris, J., et al. (2005). Evaluation of tumor angiogenesis measured with microvessel density (MVD) as a prognostic indicator in nasopharyngeal carcinoma: Results of RTOG 9505. International Journal of Radiation Oncology*Biology*Physics, 61, 745-753.

39. Fruttiger, M., Karlsson, L., Hall, A. C., et al. (1999). Defective oligodendrocyte development and severe hypomyelination in PDGF-A knockout mice. Development, 126, 457-467.

40. Fuse, T., Tanikawa, M., Nakanishi, M., et al. (2000). p27Kip1 expression by contact inhibition as a prognostic index of human glioma. J Neurochem, 74, 1393-1399.

41. Garber, K. (2010). Oncometabolite? IDH1 discoveries raise possibility of new metabolism targets in brain cancers and leukemia. J Natl Cancer Inst, 102, 926-928.

42. Gartel, A. L. (2006). Is p21 an oncogene? Mol Cancer Ther, 5, 1385-1386.

43. Giannopoulos, S. and Kyritsis, A. P. (2010). Diagnosis and management of multifocal gliomas. Oncology, 79, 306-312.

44. Gillet, E., Alentorn, A., Doukoure, B., et al. (2014). TP53 and p53 statuses and their clinical impact in diffuse low grade gliomas. J Neurooncol, 118, 131-139. 
45. Gravendeel, L. A., Kloosterhof, N. K., Bralten, L. B., et al. (2010). Segregation of non-p.R132H mutations in IDH1 in distinct molecular subtypes of glioma. Hum Mutat, 31, E1186-1199.

46. Guan, X., Vengoechea, J., Zheng, S., et al. (2014). Molecular subtypes of glioblastoma are relevant to lower grade glioma. PLoS One, 9, e91216.

47. Hanahan, D. and Weinberg, R. A. (2000). The hallmarks of cancer. Cell, 100, 57-70.

48. Hardee, M. E. and Zagzag, D. (2012). Mechanisms of Glioma-Associated Neovascularization. Am J Pathol, 181, 1126-1141.

49. Hartman, J., Edvardsson, K., Lindberg, K., et al. (2009). Tumor repressive functions of estrogen receptor beta in SW480 colon cancer cells. Cancer Res, 69, 6100-6106.

50. Ho, D. M., Hsu, C. Y., Ting, L. T., et al. (2003). MIB-1 and DNA topoisomerase II alpha could be helpful for predicting long-term survival of patients with glioblastoma. Am J Clin Pathol, 119, 715-722.

51. Houillier, C., Lejeune, J., Benouaich-Amiel, A., et al. (2006). Prognostic impact of molecular markers in a series of 220 primary glioblastomas. Cancer, 106, 22182223.

52. Hu, J. G., Fu, S. L., Wang, Y. X., et al. (2008). Platelet-derived growth factor-AA mediates oligodendrocyte lineage differentiation through activation of extracellular signal-regulated kinase signaling pathway. Neuroscience, 151, 138-147.

53. Huang, K.-T., Pavlides, S. C., Lecanda, J., et al. (2012). Estrogen and Progesterone Regulate p27kip1 Levels via the Ubiquitin-Proteasome System: Pathogenic and Therapeutic Implications for Endometrial Cancer. PLoS One, 7, e46072.

54. Huang, L. E. (2019). Friend or foe-IDH1 mutations in glioma 10 years on. Carcinogenesis, 40, 1299-1307.

55. Jackson, E. L., Garcia-Verdugo, J. M., Gil-Perotin, S., et al. (2006). PDGFR alphapositive B cells are neural stem cells in the adult SVZ that form glioma-like growths in response to increased PDGF signaling. Neuron, 51, 187-199.

56. Jijiwa, M., Demir, H., Gupta, S., et al. (2011). CD44v6 regulates growth of brain tumor stem cells partially through the AKT-mediated pathway. PLoS One, 6, e24217.

57. Jin, Q., Zhang, W., Qiu, X. G., et al. (2011). Gene expression profiling reveals Ki67 associated proliferation signature in human glioblastoma. Chin Med J (Engl), 124, 2584-2588.

58. Johannessen, A. L. and Torp, S. H. (2006). The clinical value of Ki-67/MIB-1 labeling index in human astrocytomas. Pathol Oncol Res, 12, 143-147. 
59. Johansen, M. L., Stetson, L. C., Vadmal, V., et al. (2020). Gliomas display distinct sex-based differential methylation patterns based on molecular subtype. NeuroOncology Advances, 2.

60. Johnson, D. R. and O'Neill, B. P. (2012). Glioblastoma survival in the United States before and during the temozolomide era. J Neurooncol, 107, 359-364.

61. Juratli, T. A., Engellandt, K., Lautenschlaeger, T., et al. (2013). Is There Pseudoprogression in Secondary Glioblastomas? Int J Radiat Oncol Biol Phys, 87, 1094-1099.

62. Juratli, T. A., Kirsch, M., Robel, K., et al. (2012). IDH mutations as an early and consistent marker in low-grade astrocytomas WHO grade II and their consecutive secondary high-grade gliomas. J Neurooncol, 108, 403-410.

63. Kaaijk, P., Pals, S. T., Morsink, F., et al. (1997). Differential expression of CD44 splice variants in the normal human central nervous system. J Neuroimmunol, 73, 70-76.

64. Kaminska, B., Czapski, B., Guzik, R., et al. (2019). Consequences of IDH1/2 Mutations in Gliomas and an Assessment of Inhibitors Targeting Mutated IDH Proteins. Molecules (Basel, Switzerland), 24, 968.

65. Kashi, A. S., Rakhsha, A. and Houshyari, M. (2015). Overall survival in adult patients with low-grade, supratentorial glioma: Ten years' follow up at a single institution. Electron Physician, 7, 1114-1120.

66. Kawasoe, T., Takeshima, H., Yamashita, S., et al. (2015). Detection of p53 mutations in proliferating vascular cells in glioblastoma multiforme. J Neurosurg, $122,317-323$.

67. Kfoury, N., Sun, T., Yu, K., et al. (2018). Cooperative p16 and p21 action protects female astrocytes from transformation. Acta neuropathologica communications, 6 , 12.

68. Kim, W. and Liau, L. M. (2012). IDH mutations in human glioma. Neurosurg Clin N Am, 23, 471-480.

69. Kim, Y.-H., Nobusawa, S., Mittelbronn, M., et al. (2010). Molecular Classification of Low-Grade Diffuse Gliomas. Am J Pathol, 177, 2708-2714.

70. Kirla, R. M., Haapasalo, H. K., Kalimo, H., et al. (2003). Low expression of p27 indicates a poor prognosis in patients with high-grade astrocytomas. Cancer, 97, 644-648.

71. Kleihues, P. and Ohgaki, H. (1999). Primary and secondary glioblastomas: from concept to clinical diagnosis. Neuro Oncol, 1, 44-51.

72. Kleinschmidt-DeMasters, B. K., Lillehei, K. O. and Varella-Garcia, M. (2005). Glioblastomas in the older old. Arch Pathol Lab Med, 129, 624-631. 
73. Kozak, K. R. and Moody, J. S. (2009). Giant cell glioblastoma: a glioblastoma subtype with distinct epidemiology and superior prognosis. Neuro Oncol, 11, 833-841.

74. Kuljaca, S., Liu, T., Dwarte, T., et al. (2009). The cyclin-dependent kinase inhibitor, p21(WAF1), promotes angiogenesis by repressing gene transcription of thioredoxin-binding protein 2 in cancer cells. Carcinogenesis, 30, 1865-1871.

75. Kumar, N., Kumar, P., Angurana, S. L., et al. (2013). Evaluation of outcome and prognostic factors in patients of glioblastoma multiforme: A single institution experience. Journal of Neurosciences in Rural Practice, 4, S46-S55.

76. Kushnir, I. and Tzuk-Shina, T. (2011). Efficacy of treatment for glioblastoma multiforme in elderly patients (65+): a retrospective analysis. Isr Med Assoc J, 13, 290-294.

77. Larjavaara, S., Mäntylä, R., Salminen, T., et al. (2007). Incidence of gliomas by anatomic location. Neuro Oncol, 9, 319-325.

78. Le Mercier, M., Hastir, D., Moles Lopez, X., et al. (2012). A simplified approach for the molecular classification of glioblastomas. PLoS One, 7, e45475.

79. Lee, S., Bui Nguyen, T. M., Kovalenko, D., et al. (2010). Sprouty1 inhibits angiogenesis in association with up-regulation of p21 and p27. Mol Cell Biochem, $338,255-261$.

80. Leon, S. P., Folkerth, R. D. and Black, P. M. (1996). Microvessel density is a prognostic indicator for patients with astroglial brain tumors. Cancer, 77, 362-372.

81. Liang, Y., Diehn, M., Watson, N., et al. (2005). Gene expression profiling reveals molecularly and clinically distinct subtypes of glioblastoma multiforme. Proc Natl Acad Sci U S A, 102, 5814-5819.

82. Lin, N., Yan, W., Gao, K., et al. (2014). Prevalence and Clinicopathologic Characteristics of the Molecular Subtypes in Malignant Glioma: A MultiInstitutional Analysis of 941 Cases. PLoS One, 9, e94871.

83. Liu, Y., Han, S. S., Wu, Y., et al. (2004). CD44 expression identifies astrocyterestricted precursor cells. Dev Biol, 276, 31-46.

84. Ma, X., Lv, Y., Liu, J., et al. (2009). Survival analysis of 205 patients with glioblastoma multiforme: clinical characteristics, treatment and prognosis in China. J Clin Neurosci, 16, 1595-1598.

85. Malik, N., Wang, X., Shah, S., et al. (2014). Comparison of the Gene Expression Profiles of Human Fetal Cortical Astrocytes with Pluripotent Stem Cell Derived Neural Stem Cells Identifies Human Astrocyte Markers and Signaling Pathways and Transcription Factors Active in Human Astrocytes. PLoS One, 9, e96139.

86. Mao, P., Joshi, K., Li, J., et al. (2013). Mesenchymal glioma stem cells are maintained by activated glycolytic metabolism involving aldehyde dehydrogenase 1A3. Proc Natl Acad Sci U S A, 110, 8644-8649. 
87. Meis, J. M., Martz, K. L. and Nelson, J. S. (1991). Mixed glioblastoma multiforme and sarcoma. A clinicopathologic study of 26 radiation therapy oncology group cases. Cancer, 67, 2342-2349.

88. Moller, M. B. (2000). P27 in cell cycle control and cancer. Leuk Lymphoma, 39, 19-27.

89. Mooney, K. L., Choy, W., Sidhu, S., et al. (2016). The role of CD44 in glioblastoma multiforme. J Clin Neurosci, 34, 1-5.

90. Moskowitz, S. I., Jin, T. and Prayson, R. A. (2006). Role of MIB1 in predicting survival in patients with glioblastomas. J Neurooncol, 76, 193-200.

91. Motomura, K., Natsume, A., Watanabe, R., et al. (2012). Immunohistochemical analysis-based proteomic subclassification of newly diagnosed glioblastomas. Cancer Sci, 103, 1871-1879.

92. Nakano, I. (2015). Stem cell signature in glioblastoma: therapeutic development for a moving target. J Neurosurg, 122, 324-330.

93. Naor, D., Sionov, R. V. and Ish-Shalom, D. (1997). CD44: structure, function, and association with the malignant process. Adv Cancer Res, 71, 241-319.

94. Naruse, M., Shibasaki, K., Yokoyama, S., et al. (2013). Dynamic changes of CD44 expression from progenitors to subpopulations of astrocytes and neurons in developing cerebellum. PLoS One, 8, e53109.

95. Nayak, A., Ralte, A. M., Sharma, M. C., et al. (2004). p53 protein alterations in adult astrocytic tumors and oligodendrogliomas. Neurol India, 52, 228-232.

96. Neder, L., Colli, B. O., Machado, H. R., et al. (2004). MIB-1 labeling index in astrocytic tumors a clinicopathologic study. Clin Neuropathol, 23, 262-270.

97. Nobusawa, S., Watanabe, T., Kleihues, P., et al. (2009). IDH1 mutations as molecular signature and predictive factor of secondary glioblastomas. Clin Cancer Res, 15, 6002-6007.

98. Ohgaki, H. and Kleihues, P. (2007). Genetic pathways to primary and secondary glioblastoma. Am J Pathol, 170, 1445-1453.

99. Ohgaki, H. and Kleihues, P. (2013). The definition of primary and secondary glioblastoma. Clin Cancer Res, 19, 764-772.

100. Ortensi, B., Setti, M., Osti, D., et al. (2013). Cancer stem cell contribution to glioblastoma invasiveness. Stem Cell Research \& Therapy, 4, 18.

101. Oszvald, A., Guresir, E., Setzer, M., et al. (2012). Glioblastoma therapy in the elderly and the importance of the extent of resection regardless of age. J Neurosurg, 116, 357-364.

102. Parsons, D. W., Jones, S., Zhang, X., et al. (2008). An integrated genomic analysis of human glioblastoma multiforme. Science, 321, 1807-1812. 
103. Paruthiyil, S., Parmar, H., Kerekatte, V., et al. (2004). Estrogen receptor beta inhibits human breast cancer cell proliferation and tumor formation by causing a G2 cell cycle arrest. Cancer Res, 64, 423-428.

104. Paszat, L., Laperriere, N., Groome, P., et al. (2001). A population-based study of glioblastoma multiforme. Int J Radiat Oncol Biol Phys, 51, 100-107.

105. Phillips, H. S., Kharbanda, S., Chen, R., et al. (2006). Molecular subclasses of highgrade glioma predict prognosis, delineate a pattern of disease progression, and resemble stages in neurogenesis. Cancer Cell, 9, 157-173.

106. Piva, R., Cancelli, I., Cavalla, P., et al. (1999). Proteasome-dependent degradation of p27/kip1 in gliomas. J Neuropathol Exp Neurol, 58, 691-696.

107. Popova, S. N., Bergqvist, M., Dimberg, A., et al. (2014). Subtyping of gliomas of various WHO grades by the application of immunohistochemistry. Histopathology, 64, 365-379.

108. Prochazka, L., Tesarik, R. and Turanek, J. (2014). Regulation of alternative splicing of CD44 in cancer. Cell Signal, 26, 2234-2239.

109. Ranuncolo, S. M., Ladeda, V., Specterman, S., et al. (2002). CD44 expression in human gliomas. J Surg Oncol, 79, 30-35; discussion 35-36.

110. Raysi Dehcordi, S., De Paulis, D., Marzi, S., et al. (2012). Survival prognostic factors in patients with glioblastoma: our experience. J Neurosurg Sci, 56, 239-245.

111. Reis, R. M., Hara, A., Kleihues, P., et al. (2001). Genetic evidence of the neoplastic nature of gemistocytes in astrocytomas. Acta Neuropathol, 102, 422-425.

112. Roy, S., Lahiri, D., Maji, T., et al. (2015). Recurrent Glioblastoma: Where we stand. South Asian J Cancer, 4, 163-173.

113. Ryu, M. S., Park, H. J., Moon, C. M., et al. (2018). Expression of CD44 according to Clinicopathologic Characteristics of Gastric Cancer. emj, 41, 63-74.

114. Safa, A. R., Saadatzadeh, M. R., Cohen-Gadol, A. A., et al. (2015). Glioblastoma stem cells (GSCs) epigenetic plasticity and interconversion between differentiated non-GSCs and GSCs. Genes Dis, 2, 152-163.

115. Sanson, M., Marie, Y., Paris, S., et al. (2009). Isocitrate dehydrogenase 1 codon 132 mutation is an important prognostic biomarker in gliomas. J Clin Oncol, 27, 4150 4154.

116. Sareddy, G. R., Li, X., Liu, J., et al. (2016). Selective Estrogen Receptor beta Agonist LY500307 as a Novel Therapeutic Agent for Glioblastoma. Sci Rep, 6, 24185.

117. Schomas, D. A., Laack, N. N., Rao, R. D., et al. (2009). Intracranial low-grade gliomas in adults: 30-year experience with long-term follow-up at Mayo Clinic. Neuro Oncol, 11, 437-445. 
118. Schwartzbaum, J. A., Fisher, J. L., Aldape, K. D., et al. (2006). Epidemiology and molecular pathology of glioma. Nat Clin Pract Neurol, 2, 494-503; quiz 491 p following 516.

119. Scoccianti, S., Magrini, S. M., Ricardi, U., et al. (2010). Patterns of care and survival in a retrospective analysis of 1059 patients with glioblastoma multiforme treated between 2002 and 2007: a multicenter study by the Central Nervous System Study Group of Airo (italian Association of Radiation Oncology). Neurosurgery, 67, 446-458.

120. Scott, J. G., Bauchet, L., Fraum, T. J., et al. (2012). Recursive partitioning analysis of prognostic factors for glioblastoma patients aged 70 years or older. Cancer, 118, 5595-5600.

121. Shankar, A., Kumar, S., Iskander, A., et al. (2014). Subcurative radiation significantly increases cell proliferation, invasion, and migration of primary glioblastoma multiforme in vivo. Chin J Cancer, 33, 148-158.

122. Shepard, H. M. (2015). Breaching the Castle Walls: Hyaluronan Depletion as a Therapeutic Approach to Cancer Therapy. Front Oncol, 5, 192.

123. Shivaprasad, N. V., Satish, S., Ravishankar, S., et al. (2016). Ki-67 immunostaining in astrocytomas: Association with histopathological grade - A South Indian study. Journal of Neurosciences in Rural Practice, 7, 510-514.

124. Simmons, M. L., Lamborn, K. R., Takahashi, M., et al. (2001). Analysis of complex relationships between age, p53, epidermal growth factor receptor, and survival in glioblastoma patients. Cancer Res, 61, 1122-1128.

125. Simpson, J. R., Horton, J., Scott, C., et al. (1993). Influence of location and extent of surgical resection on survival of patients with glioblastoma multiforme: results of three consecutive Radiation Therapy Oncology Group (RTOG) clinical trials. Int J Radiat Oncol Biol Phys, 26, 239-244.

126. Skjulsvik, A. J., Mørk, J. N., Torp, M. O., et al. (2014). Ki-67/MIB-1 immunostaining in a cohort of human gliomas. International Journal of Clinical and Experimental Pathology, 7, 8905-8910.

127. Sosunov, A. A., Wu, X., Tsankova, N. M., et al. (2014). Phenotypic Heterogeneity and Plasticity of Isocortical and Hippocampal Astrocytes in the Human Brain. The Journal of Neuroscience, 34, 2285-2298.

128. Stupp, R., Brada, M., van den Bent, M. J., et al. (2014). High-grade glioma: ESMO Clinical Practice Guidelines for diagnosis, treatment and follow-up. Ann Oncol, 25 Suppl 3, iii93-101.

129. Stupp, R., Mason, W. P., van den Bent, M. J., et al. (2005). Radiotherapy plus concomitant and adjuvant temozolomide for glioblastoma. N Engl J Med, 352, 987-996.

130. Sun, T., Plutynski, A., Ward, S., et al. (2015). An integrative view on sex differences in brain tumors. Cellular and Molecular Life Sciences, 72, 3323-3342. 
131. Takano, S., Kato, Y., Yamamoto, T., et al. (2012). Immunohistochemical detection of IDH1 mutation, p53, and internexin as prognostic factors of glial tumors. $J$ Neurooncol, 108, 361-373.

132. Teo, W. Y., Sekar, K., Seshachalam, P., et al. (2019). Relevance of a TCGA-derived Glioblastoma Subtype Gene-Classifier among Patient Populations. 9, 7442.

133. Thapa, R. and Wilson, G. D. (2016). The Importance of CD44 as a Stem Cell Biomarker and Therapeutic Target in Cancer. Stem Cells Int, 2016, 2087204.

134. Thota, B., Shukla, S. K., Srividya, M. R., et al. (2012). IDH1 mutations in diffusely infiltrating astrocytomas: grade specificity, association with protein expression, and clinical relevance. Am J Clin Pathol, 138, 177-184.

135. Tove, L.-L., Andreas Hanssøn, H., Stein, S., et al. (2012). Prognostic value of histological features in diffuse astrocytomas WHO grade II. International Journal of Clinical and Experimental Pathology, 5, 152-158.

136. Trabelsi, S., Chabchoub, I., Ksira, I., et al. (2016). Molecular Diagnostic and Prognostic Subtyping of Gliomas in Tunisian Population. Mol Neurobiol.

137. Tugcu, B., Postalci, L. S., Gunaldi, O., et al. (2010). Efficacy of clinical prognostic factors on survival in patients with glioblastoma. Turk Neurosurg, 20, 117-125.

138. Ulutin, C., Fayda, M., Aksu, G., et al. (2006). Primary glioblastoma multiforme in younger patients: a single-institution experience. Tumori, 92, 407-411.

139. Valle-Folgueral, J. M., Mascarenhas, L., Costa, J. A., et al. (2008). Giant cell glioblastoma: review of the literature and illustrated case. Neurocirugia (Astur), 19, 343-349.

140. van Diest, P. J., van Dam, P., Henzen-Logmans, S. C., et al. (1997). A scoring system for immunohistochemical staining: consensus report of the task force for basic research of the EORTC-GCCG. European Organization for Research and Treatment of Cancer-Gynaecological Cancer Cooperative Group. J Clin Pathol, 50, 801-804.

141. Verger, E., Valduvieco, I., Caral, L., et al. (2011). Does gender matter in glioblastoma? Clin Transl Oncol, 13, 737-741.

142. Verhaak, R. G., Hoadley, K. A., Purdom, E., et al. (2010). Integrated genomic analysis identifies clinically relevant subtypes of glioblastoma characterized by abnormalities in PDGFRA, IDH1, EGFR, and NF1. Cancer Cell, 17, 98-110.

143. Wakimoto, H., Aoyagi, M., Nakayama, T., et al. (1996). Prognostic significance of Ki-67 labeling indices obtained using MIB-1 monoclonal antibody in patients with supratentorial astrocytomas. Cancer, 77, 373-380.

144. Wang, P.-f., Liu, N., Song, H.-w., et al. (2016). IDH-1(R132H) mutation status in diffuse glioma patients: implications for classification. Oncotarget, 7, 3139331400 . 
145. Wang, X., Chen, J. X., Liu, J. P., et al. (2014). Gain of function of mutant TP53 in glioblastoma: prognosis and response to temozolomide. Ann Surg Oncol, 21, 13371344.

146. Ward, P. S., Cross, J. R., Lu, C., et al. (2012). Identification of additional IDH mutations associated with oncometabolite $\mathrm{R}(-)$-2-hydroxyglutarate production. Oncogene, 31, 2491-2498.

147. Warfel, N. A. and El-Deiry, W. S. (2013). p21WAF1 and tumourigenesis: 20 years after. Curr Opin Oncol, 25, 52-58.

148. Watanabe, K., Tachibana, O., Sata, K., et al. (1996). Overexpression of the EGF receptor and p53 mutations are mutually exclusive in the evolution of primary and secondary glioblastomas. Brain Pathol, 6, 217-223; discussion 223-214.

149. Watanabe, K., Tachibana, O., Yonekawa, Y., et al. (1997). Role of gemistocytes in astrocytoma progression. Lab Invest, 76, 277-284.

150. Weidner, N. (2008). Chapter 14. Measuring intratumoral microvessel density. Methods Enzymol, 444, 305-323.

151. Weidner, N., Semple, J. P., Welch, W. R., et al. (1991). Tumor angiogenesis and metastasis--correlation in invasive breast carcinoma. $N$ Engl J Med, 324, 1-8.

152. Xu, H., Tian, Y., Yuan, X., et al. (2015). The role of CD44 in epithelialmesenchymal transition and cancer development. OncoTargets and therapy, 8, 3783-3792.

153. Yan, H., Parsons, D. W., Jin, G., et al. (2009). IDH1 and IDH2 mutations in gliomas. N Engl J Med, 360, 765-773.

154. Yang, J., Liao, D., Wang, Z., et al. (2011). Mammalian target of rapamycin signaling pathway contributes to glioma progression and patients' prognosis. J Surg Res, 168, 97-102.

155. Yang, P., Wang, Y., Peng, X., et al. (2013). Management and survival rates in patients with glioma in China (2004-2010): a retrospective study from a singleinstitution. J Neurooncol, 113, 259-266.

156. Yang, W., Warrington, N. M., Taylor, S. J., et al. (2019). Sex differences in GBM revealed by analysis of patient imaging, transcriptome, and survival data. Science translational medicine, 11, eaao5253.

157. Yu, C. P., Ho, J. Y., Huang, Y. T., et al. (2013). Estrogen inhibits renal cell carci-noma cell progression through estrogen receptor-beta activation. PLoS One, 8, e56667.

158. Zhang, J., Yang, W. E. I., Zhao, D., et al. (2014). Correlation between TSP-1, TGF$\beta$ and PPAR- $\gamma$ expression levels and glioma microvascular density. Oncol Lett, 7, 95-100.

159. Zolota, V., Tsamandas, A. C., Aroukatos, P., et al. (2008). Expression of cell cycle inhibitors p21, p27, p14 and p16 in gliomas. Correlation with classic prognostic factors and patients' outcome. Neuropathology, 28, 35-42. 


\section{Publikācijas par pētījuma tēmu}

Zinātniskās publikācijas izdevumos, kas iekḷauti starptautiskajās datu bāzēs (SCOPUS)

1. Molecular classification of diffuse gliomas. Jakovlevs A, Vanags A, Gardovskis J, Strumfa I. Polish Journal of Pathology. 2019;70(4):246-258. doi:10.5114/pjp.2019.93126. (ir pieejams Pubmed)

2. Jakovḷevs, A., Vanags, A., Gardovskis, J., Štrumfa, I. (2020). Expression of CD44 and IDH1 R132H in Gliomas and their Prognostic Relevance, Proceedings of the Latvian Academy of Sciences. Section B. Natural, Exact, and Applied Sciences. 74(5).

3. Biserova K, Jakovlevs A, Uljanovs R, Strumfa I. Cancer Stem Cells: Significance in Origin. Pathogenesis and Treatment of Glioblastoma. Cells. 2021; 10(3):62 1 .

\section{Zinātniski raksti ārvalstīs izdotos recenzējamos izdevumos}

1. Glioblastoma - Current Concepts, Prognostic Markers And Molecular Classification / A.Jakovlevs, A.Vanags, D.Balodis, J.Gardovskis, I.Strumfa // Acta Chirurgica Latviensis. - No.13/1 (2013), p. 58-64.

2. Childhood medulloblastoma in Latvia: morphologic and molecular implications for diagnostics and personalised treatment / I.Franckevica, A.Jakovlevs, A.Abolins, A.Vanags, I.Strumfa ...[et al.] // Acta Chirurgica Latviensis. - No.16/1 (2016), p. 9-15.

3. Solitary and multiple meningiomas : an immunohistochemical comparison / B.Vikmane, A.Jakovlevs, A.Vanags, I.Strumfa // Acta Chirurgica Latviensis. - No.15/1 (2015), p. 23-28. 
4. Prolonged survival after neurosurgical resection of lung cancer metastasis / A.Jakovlevs, A.Vanags, I.Strumfa ...[et al.] // Acta Chirurgica Latviensis. No.14/1 (2014), p. 32-34.

5. Recurrent multiple atypical meningiomas despite neurosurgical resection / A.Jakovlevs, I.Strumfa, A.Vanags ...[et al.] // Acta Chirurgica Latviensis. No. 14/2 (2014), p. 56-58.

6. Low-grade rhabdoid meningioma : unusual morphological characteristics / A.Jakovlevs, A.Vanags, J.Gardovskis, I.Strumfa // Acta Chirurgica Latviensis. - No. 13/1 (2013), p. 84-86.

\section{Tēzes un uzstāšanās starptautiska mēroga konferencēs un kongresos}

1. A. Jakovlevs, J. Gardovskis, I. Štrumfa. Ki-67 labeling index and CD44 expression in gliomas: does the gender matter? 10th Baltic Morphology Scientific Conference, 24.-25.10.2019, Kaunas, Lithuania.Abstract Book page 262 .

2. A.Jakovlevs, J.Gardovskis, I.Štrumfa. Prognostic impact and correlations of Ki-67 labeling index and CD44 expression in gliomas. 10th Baltic Morphology Scientific Conference, 24.-25.10.2019, Kaunas, Lithuania. Abstract Book page 261.

3. Arvids Jakovlevs, Ilze Strumfa, Janis Gardovskis. Prognostic Role of Ki-67 Labeling Index in Diffuse Gliomas // Rīga Stradiṇš University International Conference on Medical and Health Care Sciences Knowledge; 01.-03.04. 2019., Riga, Latvia; Tēžu grāmata 730 lpp.

4. Arvids Jakovlevs, Ilze Strumfa, Janis Gardovskis. Prognostic and Predictive Significance of Immunohistochemically Defined Molecular Subclasses in Glioblastoma // Rīga Stradiņš University International Conference on Medical 
and Health Care Sciences Knowledge, 01.-03.04. 2019., Riga, Latvia; Tēžu grāmata 729 lpp.

5. Ilze Strumfa, Dz. Mezale, Guntis Bahs, Andrejs Vanags, Dr. Ilze Fridrihsone, Dr. A. Jakovlevs. Digital Pathology in Education: Experience of Rīga Stradiņš University // Rīga Stradiņš University International Conference on Medical and Health Care Sciences Knowledge, 01.-03.04.2019, Riga, Latvia; Tēžu grāmata $741 \mathrm{lpp}$.

6. Assessment of microvascular density in gliomas: diagnostic and prognostic significance / A. Jakovlevs, A. Vanags, J. Gardovskis, I. Strumfa // Baltic Morphology IX (Tartu, Estonia, Sept. 27-29, 2017): Conference Programme : Abstracts of Presentations / University of Tartu. - Tartu, 2017. - P. 34.

7. Pleomorphic xanthoastrocytoma - a rare type of cerebral glioma / A. Jakovlevs, A. Vanags, J. Gardovskis, I. Strumfa // Baltic Morphology IX (Tartu, Estonia, Sept. 27-29, 2017): Conference Programme : Abstracts of Presentations / University of Tartu. - Tartu, 2017. - P. 35.

8. Prognostic and predictive role of proneural and mesenchymal molecular signatures in glioblastoma / A. Jakovlevs, A. Vanags, J. Gardovskis, I. Strumfa // 8th Mildred Scheel Cancer Conference (Bonn, Germany, June 14-16, 2017) : Programme and Abstracts. - Bonn, 2017. - P.148.

9. Expression of aberrant p53 protein in medulloblastoma [Elektroniskais resurss] / G. Kirsakmens, I. Franckevica, L. Kolomencikova, A. Jakovlevs, D. Balodis, I. Strumfa // International Symposium "Targets of immunotherapy of chronic viral infections and cancer" (Riga, Latvia, May 24-26, 2016)[Elektroniskais resurss] : Abstract Book. - Riga, 2016. - 1 p., on CD.

10. p53 protein as a potential target of cancer vaccines in glioblastomas [Elektroniskais resurss] / A. Jakovlevs, A. Vanags, J. Gardovskis, I. Strumfa 
// International Symposium "Targets of immunotherapy of chronic viral infections and cancer" (Riga, Latvia, May 24-26, 2016) [Elektroniskais resurss] : Abstract Book. - Riga, 2016. - 1 p., on CD.

11. Jakovḷevs, Arvīds. IDH1-R132 immunohistochemistry in human gliomas: a way to improved diagnostics / A. Jakovlevs, A. Vanags, I. Strumfa // Eesti Arst. - Suppl.2 (2015, Sept.), p.68. - 8th Congress of the Baltic Association of Surgeons (Tallinn, Estonia, Sept.10-12, 2015): [Abstracts].

12. Jakovḷevs, Arvīds. Immunohistochemical analysis of platelet-derived growth factor receptor-alpha (PDGFRA) expression in gliomas / A. Jakovlevs, A. Vanags, I. Strumfa // The 8th Baltic Morphology Scientific Conference "Interdisciplinary nature of contemporary morphology" (Vilnius, Lithuania, Nov. 12-14, 2015) : [Abstract Book] / Vilnius University. - Vilnius, 2015. - P. 90.

13. Jakovḷevs, Arvīds. The spectrum of brain metastases / A. Jakovlevs, A. Vanags, I. Strumfa // The 8th Baltic Morphology Scientific Conference "Interdisciplinary nature of contemporary morphology" (Vilnius, Lithuania, Nov. 12 14, 2015) : [Abstract Book] / Vilnius University. - Vilnius, 2015. - P.91.

14. Heterogeneity of Ki-67 and p53 expression in glioblastomas : [abstract] / A. Jakovlevs, I. Strumfa, A. Vanags, J. Gardovskis // Virchows Archiv. Vol.465, Suppl.1 (2014, Aug.), p.S352. - Starptautiski citējamā izdevumā. London. United Kingdom.

15. Lipoastrocytoma of the spinal cord mimicking lipoma : [abstract] / A. Jakovlevs, I. Strumfa, A. Vanags, J. Gardovskis // Virchows Archiv. Vol.465, Suppl.1 (2014, Aug.), p.S353. - Starptautiski citējamā izdevumā. London. United Kingdom. 
16. Low-grade rhabdoid meningioma - unusual morphological characteristics / A. Jakovḷevs, L. Feldmane, I. Štrumfa, J. Gardovskis // Baltic Morphology VII Scientific Conference "Morphological sciences in the experimental and clinical medicine” (Rīga, Latvia, Nov.7-9, 2013) : Abstract Book / Riga Stradiņš University. - Riga, 2013. - P.85.

\section{Tēzes un uzstāšanās Latvijas (vietējā) mēroga konferencēs un kongresos}

1. Prognostic role of CD44 expression in diffuse gliomas / A. Jakovḷevs, A. Vanags, J. Gardovskis, I. Štrumfa // 2018. gada Zinātniskās konferences tēzes (Rīga, 2018. g. 22.-23.martā) / Rīgas Stradiṇa universitāte. - Rīga, 2018. - 165. lpp.

2. Survival analysis of patients with diffuse gliomas in Latvia / A. Jakovḷevs, A. Vanags, J. Gardovskis, I. Štrumfa // 2018. gada Zinātniskās konferences tēzes (Rīga, 2018.g. 22.-23.martā) / Rīgas Stradiņa universitāte. - Rīga, 2018. - 164. lpp.

3. $\mathrm{p} 27$ and $\mathrm{p} 21$ protein expression in gliomas and their prognostic relevance / A. Jakovlevs, A. Vanags, J. Gardovskis, I. Strumfa // 2017. gada Zinātniskās konferences tēzes (Rīga, 2017.g. 6.-7.aprīīi) / Rīgas Stradiṇa universitāte. Rīga, 2017. - 210. lpp.

4. Prognostic role of platelet derived growth factor receptor alpha expression in diffuse gliomas / A. Jakovlevs, A. Vanags, J. Gardovskis, I. Strumfa // 2017. gada Zinātniskās konferences tēzes (Rīga, 2017.g. 6.-7.aprīīi) / Rīgas Stradiṇa universitāte. - Rīga, 2017. - 209. lpp.

5. IDH1 R132H mutanta proteīna ekspresijas biežums difūzās astrocitomās / A. Jakovḷevs, A. Vanags, J. Gardovskis, I. Štrumfa // 2016.gada Zinātniskās konferences tēzes (Rīga, 2016. g. 17.-18.martā) / Rīgas Stradiṇa universitāte. - Rīga, 2016. - 191. lpp. 
6. p21 un p53 proteīna ekspresija gliālos audzējos / A. Jakovḷevs, A. Vanags, I. Štrumfa, J. Gardovskis // 2016. gada Zinātniskās konferences tēzes (Rīga, 2016. g. 17.-18.martā) / Rīgas Stradiṇa universitāte. - Rīga, 2016. - 192. lpp.

7. CD44 proteīna ekspresija gliālos audzējos / A. Jakovḷevs, A. Vanags, J. Gardovskis, I. Štrumfa // 2015. gada Zinātniskās konferences tēzes (Rīga, 2015.g. 26.-27.martā) / Rīgas Stradiņa universitāte. - Rīga, 2015. - 281. lpp.

8. Primārās un sekundārās glioblastomas operāciju materiālā pacientiem Latvijā / A. Jakovḷevs, A. Vanags, J. Gardovskis, A. Āboliņš, I. Štrumfa // 2015. gada Zinātniskās konferences tēzes (Rīga, 2015. g. 26.-27.martā) / Rīgas Stradiṇa universitāte. - Rīga, 2015. - 280. lpp.

9. Anaplastiska hemangiopericitoma - rets smadzeņu apvalku audzējs / A. Jakovḷevs, A. Vanags, J. Gardovskis, I. Štrumfa ...[u. c.] // 2014. gada Zinātniskās konferences tēzes (Rīga, 2014.g. 10.-11. aprīlī) / Rīgas Stradiṇa universitāte. - Rīga, 2014. - 294. lpp.

10. Gliosarkoma - rets gliāls audzējs bērnu vecumā / A. Jakovḷevs, A. Vanags, J. Gardovskis, I. Štrumfa // 2014. gada Zinātniskās konferences tēzes (Rīga, 2014.g. 10.-11.aprīlī) / Rīgas Stradiṇa universitāte. - Rīga, 2014. - 308. lpp.

11. Gliosarkomu diagnostiskie un prognostiskie marķieri / A. Jakovḷevs, A. Vanags, J. Gardovskis, I. Štrumfa // 2014. gada Zinātniskās konferences tēzes (Rīga, 2014.g. 10.-11.aprìlī) / Rīgas Stradina universitāte. Rīga, 2014. - 293. lpp.

12. Ki-67 proliferācijas indeksa un p53 proteīna ekspresijas heterogenitāte glioblastomās / A. Jakovḷevs, A. Vanags, J. Gardovskis, I. Štrumfa // 2014. gada Zinātniskās konferences tēzes (Rīga, 2014.g. 10.-11.aprīlī) / Rīgas Stradiṇa universitāte. - Rīga, 2014. - 309. 1pp. 
13. CNS audzēju morfoloǵiskais spektrs operāciju un stereotaktisku biopsiju materiālā / A. Jakovḷevs, A. Vanags, J. Gardovskis, I. Štrumfa // 2013. gada Zinātniskās konferences tēzes (Rīga, 2013.g. 21.-22.martā) / Rīgas Stradiṇa universitāte. - Rīga, 2013. - 267. lpp. 